UNIVERSIDADE DE SÃO PAULO

FACULDADE DE FILOSOFIA, LETRAS E CIÊNCIAS HUMANAS

DEPARTAMENTO DE LETRAS MODERNAS

PROGRAMA DE PÓS-GRADUAÇÃO EM ESTUDOS LINGÜÍSTICOS E LITERÁRIOS EM INGLÊS

JULIANA ROSENTHAL KNOEPFELMACHER

A QUESTÃO DA MULHER E A ORDEM SOCIAL:

O HUMOR EM DOROTHY PARKER

São Paulo

2008 


\author{
UNIVERSIDADE DE SÃO PAULO \\ FACULDADE DE FILOSOFIA, LETRAS E CIÊNCIAS HUMANAS \\ DEPARTAMENTO DE LETRAS MODERNAS \\ PROGRAMA DE PÓS-GRADUAÇÃO EM ESTUDOS LINGÜÍSTICOS E \\ LITERÁRIOS EM INGLÊS
}

\title{
A QUESTÃO DA MULHER E A ORDEM SOCIAL: O HUMOR EM DOROTHY PARKER
}

Juliana Rosenthal Knoepfelmacher

\begin{abstract}
Dissertação apresentada ao Programa de PósGraduação do Departamento de Letras Modernas, na área de Estudos Lingüísticos e Literários em Inglês, da Faculdade de Filosofia, Letras e Ciências Humanas da Universidade de São Paulo, para a obtenção do título de Mestre em Estudos Lingüísticos e Literários em Inglês.
\end{abstract}

Orientadora: Prof. ${ }^{a}$ Dr. ${ }^{a}$ Laura Patrícia Zuntini de Izarra

São Paulo

2008 


\section{RESUMO}

Essa dissertação tem como objetivo analisar os contos da escritora Dorothy Parker em diálogo com seus poemas, tendo em vista a modernidade com a qual construiu suas histórias e o papel do humor em sua criação. Ao analisar as obras dessa autora de grande destaque nos Estados Unidos da América do Norte, nos anos 1930, veremos como o humor se transforma numa importante ferramenta que se relaciona com a construção do feminino e com a questão social da mulher, a fim de desestabilizar e transformar o status quo. O estudo, com o apoio teórico de Vladimir Propp e de Henri Bergson, intenciona demonstrar que, embora Dorothy Parker possa ser considerada uma escritora "datada", seu senso satírico continua atual e reflete claramente o contexto no qual as mulheres estavam inseridas.

Palavras-chave: humor, sátira, mulher, conto, Estados Unidos da América. 


\begin{abstract}
The aim of this study is to analyse Dorothy Parker's short stories in dialogue with her poems in order to show the modernity of her writings and the function played by humour. Analysing the works of the great american writer in the thirties, we see how humour is used as a tool in the construction of the feminine and the social role of women, with the purpose of destabilizing and making a change in the status quo. The theoretical framework based on Vladimir Propp and Henri Bergson helps to demonstrate that in spite of Dorothy Parker's work being considered dated by some, the satiric sense that emerges from her writings is still present in our times and reveals the context in which those women were inserted.
\end{abstract}

Keywords: humour, satire, woman, short story, United States of America. 


\section{SUMÁRIO}

INTRODUÇÃO 5

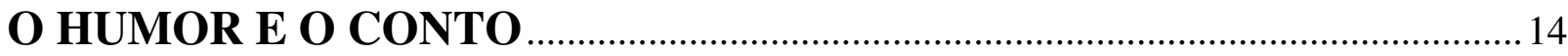

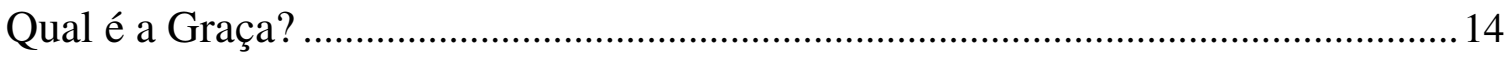

A Tradição Masculina e o Humor Feminino........................................................... 22

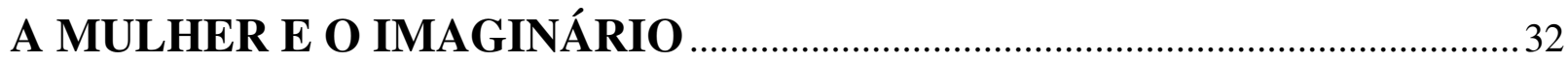

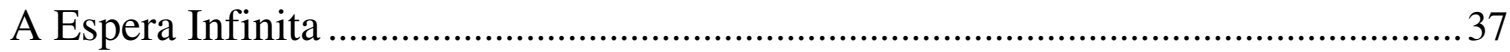

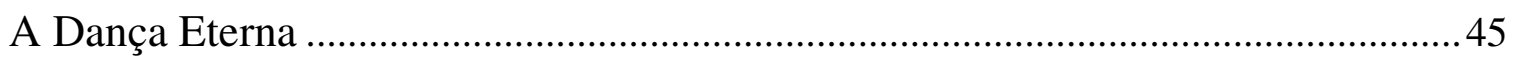

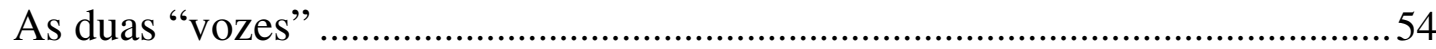

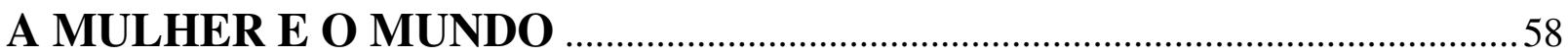

O Amor nos Tempos de Guerra ..............................................................................59

O Desejo de Vingança ...............................................................................................

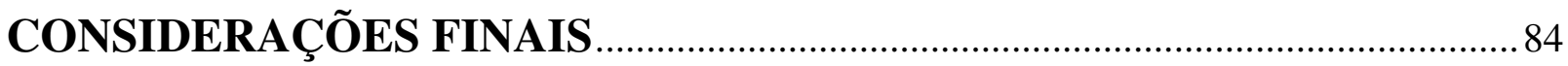

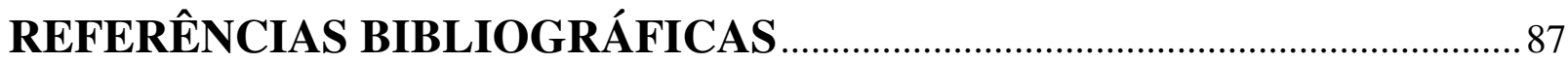




\section{INTRODUÇÃO}

A análise dos contos de Dorothy Parker (1893-1967), considerada nos anos 1920 "the wittiest woman in América", e por muitos a primeira escritora a tratar da dependência feminina com uma visão moderna, é uma tarefa extremamente relevante, pois estabelece uma relação entre a questão feminina e sua expressão social através do texto literário.

Assim, o objetivo dessa dissertação é identificar, por meio da análise de quatro de seus contos ${ }^{1}$, “A Telephone Call” (1928), "The Waltz” (1933), “The Lovely Leave” (1943) e "The Banquet of Crow" (1957), o modo como o humor se relaciona com esses dois elementos, a construção do feminino e a questão social da mulher, tornando-se um elemento desestabilizador e transformador do status quo.

Para abordar a maneira como essa temática social feminina é vista por Dorothy Parker, assim como a representação da mulher na narrativa via construção das personagens, a dissertação enfoca os contos relacionando-os com a sua época, com o restante da obra da autora, inclusive sua poesia, e com o posicionamento da autora em relação à mulher. Também a escolha de contos pertencentes às diferentes décadas nos permite acompanhar a perspectiva histórica da condição da mulher dentro da sociedade.

A temática da dependência feminina é uma constante na produção literária de Dorothy Parker, e a nossa opção por estes quatro contos deve-se, preponderantemente, à presença do humor, apresentado como uma saída para a quebra dos paradigmas, como meio de subversão dos valores patriarcais e como possibilitador de uma nova consciência.

A tarefa do escritor, para Parker, é mostrar sem tentar provar, selecionando cuidadosamente entre as contradições da vida os elementos importantes que, unidos uns aos outros, imprimirão seu sentido à narrativa.

Além de Dorothy Parker ter sido uma das únicas mulheres a trabalhar como crítica de teatro e de livros para revistas como Vogue, Esquire, Vanity Fair e The New Yorker, uma grande quantidade de seus poemas publicados em três coleções de poesia - Enough

\footnotetext{
${ }^{1}$ Foi adotada a edição Dorothy Parker Complete Stories. USA. Penguin Books, 2003 para a análise dos contos. Para a tradução dos contos "A Telephone Call", "The Waltz", "Arrangement in Black and White" e "Big Blonde", uma vez que há publicação na língua portuguesa, foi utilizado o livro PARKER, Dorothy. Big Loira e outras histórias de Nova York. Tradução Ruy Castro São Paulo: Companhia das Letras, 1987. Os demais contos analisados, "The Lovely Leave" e "The Banquet of Crow", assim como os poemas, por não haver tradução, foram mantidos somente no original em inglês.
} 
Rope (1926), Sunset Gun (1928) e Death and Taxes (1931) foram nelas primeiramente expostos. Parker também colaborou com diversos roteiros em Hollywood e escreveu e colaborou com cinco peças teatrais: Close Harmony (1924) The Happiest Man (1939) The Coast of Ilyria (1949), The Ladies of the Corridor (1953) e The Ice Age (1955).

Seu primeiro livro de poesias, Enough Rope, foi publicado em 1926, e, devido ao seu humor e à presença de situações e sentimentos facilmente identificáveis para as mulheres, se tornou um bestseller. Nos dois livros seguintes, Sunset Gun de 1928 e Death and Taxes de 1931, alguns de seus poemas passaram a abordar assuntos como, por exemplo, as guerras, mas sem deixar de lançar um olhar satírico sobre a relação entre os sexos. No entanto, foram seus contos que obtiveram um indiscutível destaque. De acordo com Brendan Gill, seus contos na revista The New Yorker, recém fundada por Harold Ross em 1925, que inicialmente não continham mais do que sobras de um diálogo atormentado, levaram ao desenvolvimento do que posteriormente viria a ser um gênero reconhecido como as "The New Yorker short story". Laments for the Living, sua primeira coletânea de contos de ficção foi publicada em 1930 e em seguida foram publicados After Such Pleasures (1933) e Here Lies (1939). Sua escrita também foi refinada ao longo de sua produção, e as frustrações, os encantos, as complicações e o humor presentes no mundo feminino foram cuidadosamente examinados.

Os autores e oradores mais importantes dessa época são os pertencentes à Geração Perdida, nome dado por Gertrude Stein ao grupo de jovens escritores americanos que viveram na Europa depois da I Guerra Mundial. O grupo incluia John dos Passos, F. Scott Fitzgerald e Ezra Pound, entre outros. O mais famoso deles foi Ernest Hemingway. Sua narrativa dispersa e diálogo focado representam o modelo da ficção moderna. Algumas comparações foram feitas entre ele e Dorothy Parker. A crítica Fanny Butcher disse:

He works from the outside, with thought and emotion implied by the action. She works from the inside, with thought set down and action and outside pressure inferred. But they both reach the highly emotional reaction of reality in their readers. ${ }^{2}$

Outro comentário, que aproxima o estilo de ambos os escritores foi feito por Gladys Graham, do Saturday Review of Literature: "Mrs. Parker deixa de fora os detalhes com

\footnotetext{
2"Ele trabalha de fora para dentro, com os pensamentos e as emoções incluídos nas ações. Ela trabalha de dentro para fora, com pensamentos colocados e ação e pressão exterior inferida". PETTIT, Rhonda. $A$ gendered collision: sentimentalism and modernism in Dorothy Parker's poetry and fiction. Cranbury, NJ: Fairleigh Dickinson University Press, 2000. p. 51 (Tradução nossa)
} 
uma falta de piedade não igualada em nenhum outro lugar, nesta geração influenciada por Hemingway, de concisão e ruptura." ${ }^{\text {(tradução nossa) }}$

Algumas comparações têm sua base na questão de gênero, e críticos chegam a considerar Parker um Hemingway “de saias”.

Morrie Ryskind do The New York Herald Tribune escreveu:

Dorothy Parker has the sort of mind that we males, for want of a better world, have labeled "masculine," just as we label the movie hero who fights his way through fire and flood a "manly" fellow. When the wits of the town are mentioned in print or gathered in fun, she is sure to be included in the otherwise male group. She speaks the language of the boys, she knows all the words, but she speaks, nevertheless, in a woman's voice. Just as she sees with a woman's eyes. ${ }^{4}$

Porém, por seus contos terem sido publicados em várias revistas femininas, o apelo popular de Dorothy Parker a separou dos escritores encontrados em revistas menores e literárias, como T.S. Eliot e Ezra Pound, entre outros, que mais tarde viriam a compor o cânone modernista.

Em 1920, a América dança em meio à grande queda de Wall Street, mas ainda a ignora. $\mathrm{O}$ ano se anuncia promissor. Henri Bergson recebe o Prêmio Nobel de literatura, os Harlem Globe Trotters fazem seus primeiros dribles infernais e o fox-trot suplanta o charleston. Essa década, marcada em seu início pela Guerra e em seu fim pela Grande Depressão, foi reconhecida por seu poder de tolerância e encorajamento. Todas as formas de revolta, protestos, sátira e experimentações eram admitidas.

Dorothy Parker, de alma anarquista e sempre dedicada aos menos favorecidos, não exita, então, em criticar os homens pretensiosos e hipócritas que se escondem atrás da política esquerdista e da arte, e é presa por protestar na execução de Sacco e Vanzetti.

No decorrer dos anos 1920, o estilo Parker começa a ser consolidado, a forma satírica que usa para descrever a condição feminina nas relações amorosas se afirma de conto para conto, e é a partir de uma das histórias que analisaremos, "A Telephone Call",

\footnotetext{
${ }^{33}$ Mrs. Parker can cut away detail with a ruthlessness not to be equaled elsewhere in this Hemingway-Held, brevity-or-burst generation." PETTIT, Rhonda. op. cit., p. 51.

4،"Dorothy Parker tem o tipo de mente que nós, homens, pelo desejo de um mundo melhor, rotulamos de "masculina", assim como rotulamos o herói de um filme que adentra o fogo e salva seu camarada. Quando situações e frases espirituosas são mencionadas numa publicação ou ditas por um grupo de amigos, ela certamente será incluída no grupo masculino. Ela fala a língua dos homens, ela sabe todas as palavras, mas ela fala, entretanto, em uma voz feminina. Assim como ela enxerga com olhos de mulher." PETTIT, Rhonda. op. cit., p. 53. (Tradução nossa).
} 
desse mesmo ano, que Parker estabelece os temas que virá a refinar em toda a sua obra: a impossibilidade da relação verdadeira entre um homem e uma mulher, a necessidade que têm os sexos opostos de representar papéis estereotipados e a dependência feminina.

Em seu poema "General Review of the Sex Situation", da coleção Enough Rope de 1926, já podemos perceber essas características, permeadas por um grande humor.

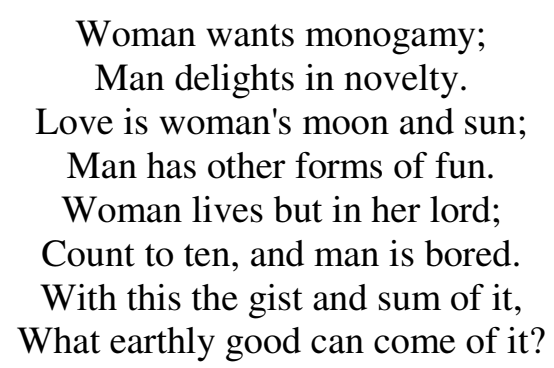

Apontando as diferenças de interesses e necessidades, a autora mostra ser inviável uma relação "saudável” entre os sexos.

Dorothy Parker pertenceu a uma sociedade em transição, pois apesar de ser um período em que, formalmente, as reivindicações das mulheres haviam sido atendidas (podiam votar e ser votadas, ingressar nas instituições escolares, sair sozinhas, experimentar álcool e tabaco, participar do mercado de trabalho), com o fim da guerra e o retorno da força de trabalho masculina, a ideologia que valorizava a diferenciação de papéis por sexo, atribuindo à condição feminina o espaço doméstico, foi fortemente reativada, no sentido de ceder os lugares no mercado de trabalho aos homens.

Começando com encontros informais na hora do almoço no Hotel Algonquin, em Nova York, Franklin Pierce Adams, Harold Ross, Heywood Brown, Robert Benchley, Robert Sherwood, Dorothy Parker, e outros se unem para criar, então, uma nova cultura, uma nova linguagem adequada a uma América liberta da velha Europa. É formado deste modo o Algonquin Round Table. Um curioso cenáculo, demolidor das convenções, mas inflexível quanto ao estilo. De certa forma semelhante a outro círculo fechado, o grupo de Bloomsbury, que, do outro lado do Atlântico, em Londres, em torno de Virgínia Woolf, Duncan Grant e Roger Fry, entre outros, batalhava já há uma década pela liberdade de pensamento, pela quebra dos tabus e da hipocrisia. Diferentemente dos Bloomsbury, entretanto, os algonquinos não concebiam a reflexão e a crítica dissociadas do humor.

\footnotetext{
${ }^{5}$ Os poemas foram retirados do livro: PARKER, Dorothy. The poetry and short stories of Dorothy Parker. New York: The Modern Library, 1994.
} 
Parker era uma das únicas mulheres em meio a este grupo de homens que passavam as noites rindo, bebendo e discutindo literatura no bar do Hotel.

Tal clima de aparente liberdade impulsionou também a luta feminista, uma vez que a mulher começou a discutir seu papel nessa sociedade regida por novos valores que favoreceram sua independência, não mais a restringindo ao universo familiar. Uma realidade diversa que lhe oferecia a oportunidade de contestar os paradigmas que lhe haviam sido impostos.

Parker assume esse posicionamento libertário tanto em sua vida como em seus escritos, fazendo da parcela da sociedade que ainda se encontra impedida de desenvolver seu potencial e é condenada a viver à sombra de seus homens, suas personagens, mostrando as causas e discutindo as conseqüências destas imposições.

Em seu poema Anecdote de 1926, podemos perceber com evidência essa questão da subordinação feminina:

So silent I when Love was by

He yawned, and turned away;

But Sorrow clings to my apron-strings,

I have so much to say

Embora sua poesia não tenha ganhado um valor estético de ressonância, seu estilo se consolidou e em 1929, ela ganhou o Prêmio National Henry O. pelo conto "Big Blonde", e se tornou a escritora mais citada em NovaYork. Alexander Woollcott, em seu artigo "Our Mrs. Parker", para a Revista Cosmopolitan a caracterizou como "uma estranha mistura de Pequena Sereia e Lady Macbeth", e classificou seu trabalho como uma "potente destilação de néctar e absinto, de ambrosia e beladona”. (1934, p. 38)

A recepção de seu trabalho durante o século XX, porém, foi marcada por diferentes opiniões críticas. Mesmo tratando de temas universais como relações humanas, amor romântico, família, guerra, racismo, decepções pessoais, disparidade econômica e a intersecção desses temas, Parker foi chamada de escritora datada, circunstancial, humorista e pejorativamente falando, de sentimentalista.

A sentimentalidade de suas obras foi uma preocupação recorrente dos críticos na metade dos anos trinta até os anos sessenta, quando novos valores críticos tomaram lugar na academia. A partir disso, a pergunta que surge é como se dá essa sentimentalidade, de que maneiras ela se apresenta, e se invalidaria a obra da autora ou se, na verdade, 
funcionaria como uma máscara crítica, profunda e feroz ao comportamento imposto às mulheres da época.

Inicialmente, os críticos elogiaram sua habilidade, seu humor engenhoso e sua concisão. Porém, apontaram que muitos dos trabalhos ficcionais de Parker são autobiográficos em sua natureza, e significativamente, a crítica recorrente de sua obra, e sua vida, é de que seria sentimental e superficial.

Essa reação ao trabalho da autora se deve à influência de uma crítica modernista iniciada por I. A. Richards, Ezra Pound e T. S. Elliot, a qual não somente privilegiava o trabalho literário como um objeto de arte desprovido de contexto, considerando-o como um todo autônomo e auto-suficiente, mas simplificava e negava a tradição sentimental.

O entendimento daquilo a que nos referimos como "sentimental" sofreu mudanças ao longo do tempo, passando de sentimentos profundos ainda que limitados pela razão no século dezoito, para um idealismo feminilizado sobre a natureza humana no século dezenove, culminando com um excesso emocional de pouco valor no século vinte. No século vinte, "sentimental" torna-se, em grande medida, um termo pejorativo. Essa preocupação recorrente se tornou um alvo crescente do meio dos anos 1930 até os anos 1960, quando os valores da Nova Crítica são desenvolvidos na Academia.

Ao mesmo tempo em que autobiografias afetuosas sobre o Algonquin Round Table como The Vicious Circle (1951) e The Time of Laughter (1967) foram publicadas nos anos 1950 e 1960, assim como vários artigos em revistas, se tornou uma moda desmistificar os talentos do grupo. James R. Gaines enfatizou a falta de disciplina, a obscuridade psicológica, e a dependência emocional dos integrantes em seu retrato do grupo de 1977, The Wit's End. Ross Labrie proclamou que o talento do grupo estava ultrapassado em seu artigo para o The Canadian Review of American Studies. Até mesmo Brendan Gill, que conhecia Dorothy Parker e escreveu a introdução da edição de seu livro The Portable Dorothy Parker, de 1973, elogiou sua prosa e sua poesia, mas nomeou seu trabalho um produto dos anos 1920.

Os rótulos aplicados ao trabalho de Parker - "humorista", "light verse writer", "escritora datada" - possuem, com exceção deste último, algum mérito, mas claramente refletem o contexto restrito no qual seu trabalho foi lido.

O tema do amor, em suas histórias, marcara a discussão sobre as relações de poder nas relações heterossexuais, e veremos que a linguagem esvaziada é utilizada de modo a 
capturar o modo de comunicação entre os sexos, tanto particularmente na cultura dos anos 1920, como nas dificuldades gerais de uma relação amorosa, em qualquer lugar ou época. Ironicamente, o sucesso de Dorothy Parker com essa técnica foi interpretada por alguns críticos que a rotularam de escritora datada, e sua representatividade de um determinado período como uma limitação. Para Rhonda S. Pettit (2000), a aparente acessibilidade dos textos de Parker pode ser enganosa, pois quanto mais seus leitores souberem sobre as tradições da época na qual sua obra foi produzida, melhor entenderão seu papel no modernismo do século XX. Para Pettit, a ausência de retórica e narração, assim como a concisão, a economia, e o fluxo de consciência encontrado em seus monólogos e diálogos a colocaram na companhia de James Joyce, Gertrude Stein, Virginia Wolf, e Ernest Hemingway. Ela também observou a ausência de fechamento nas histórias de Parker como uma característica moderna.

Essa modernidade pode ser percebida no uso da ironia e da forma abreviada, mas também na escolha de suas personagens, e no conteúdo de suas histórias. Dorothy Parker foi uma crítica severa dos padrões de comportamento imposto às mulheres. Susanne L. Bunkers (1978) proferiu que as personagens femininas de Parker geralmente invocam reações mistas do leitor, são dignas de pena, ao mesmo tempo que irritam. Elas parecem vitimizadas não somente por uma sociedade opressora, mas também pela sua inabilidade de lutar contra essa mesma sociedade. Bunkers também defendeu a renegada profundidade e o alcance do trabalho de Parker, quando disse que seus poemas e contos não são simplesmente "cute" ou "funny", eles também funcionam como um veículo para a crítica social. Ela salientou o uso de personagens femininas estereotipadas para satirizar, com mais amargura do que diversão, os papéis limitados que são impostos às mulheres na América durante os anos 1920 e 1930, décadas nas quais a imagem predominante das mulheres era a de libertária.

No final dos anos setenta, Arthur F. Kinney (1978) publicou o primeiro estudo completo do trabalho de Parker, no qual faz muitas ligações da obra à vida particular da autora, mas também a analisa além da sua representatividade junto ao grupo do Algonguin Round Table. Ao mesmo tempo, a segunda onda do Feminismo trouxe interesse renovado em seu trabalho. Para Emily Toth (1977), a inteligência viva de Dorothy Parker era uma arma e ao se especializar nas verdades escondidas nas relações, e manipular o jogo de esconder e revelar, a escritora se tornou o melhor exemplo do humor tradicional feminino. 
Porém, nem todos compartilham dessa opinião. No prefácio de sua obra The Best of Modern Humor de 1983, Mordecai Richler explicou não ter incluído o trabalho de Parker por achá-lo "brittle, short on substance, and ... no longer very funny".

Já Regina Barreca (1995) questionou essa recusa à valorização do trabalho de Parker, levantando a hipótese de uma possível inspiração misógina. Ela se perguntou o porquê de muitos críticos parecerem tão concentrados em reduzir a importância dos escritos da autora, e respondeu que muitos de seus críticos do sexo masculino parecem se ressentir da relutância de Parker em satisfazer seu apetite literário, pois a autora não tinha entre seus vários talentos a habilidade de "play well with others", ou seja, não atenuava suas opiniões críticas em favor de ser agradável com quem quer que fosse.

Alguns críticos, como John Mair (1939), se referiram mais diretamente à questão da autoria ligada ao sexo e gênero, especialmente às diferenças entre escritores e escritoras. Para Mair, Parker rompeu com esses limites. Comparando seu "humorous detachment" com o de Jane Austen, Mair proferiu que apesar de Parker ser dotada do que é normalmente chamado de uma inteligência "masculina", o ponto de vista de suas histórias é feminino, e por ser muito mais dura com as estupidezes femininas do que com as masculinas, seu trabalho pode ser considerado um guia seguro para o inferno da classe média feminina. Ele também a classificou como um dos primeiros frutos da emancipação feminina. Essa opinião, porém, levanta uma problemática. Se Parker possuiu um ponto de vista feminino em virtude de enfocar e criticar personagens femininas, o que seria "inteligência masculina"?

Podemos perceber, dessa forma, que a maior parte da crítica do trabalho de Dorothy Parker enfoca temas como sentimentalismo, modernismo e feminismo. Nosso trabalho, no entanto, pretende focalizar um outro viés, o modo como este humor, tão característico de seus escritos, ao se relacionar com a questão social da mulher e com a construção do feminino, permite uma reação aos paradigmas da sociedade em relação à mulher e uma possível mudança em seu comportamento.

Desse modo, o primeiro capítulo dessa dissertação se centrará na questão do humor e no gênero escolhido pela autora, o conto. Será estabelecido um diálogo entre as teorias do humor e do conto, a fim de desvendar a estrutura que Dorothy Parker propõe em suas histórias. 
No segundo capítulo analisaremos dois de seus contos, “A Telephone Call” (1928), e "The Waltz" (1933), assim como a escolha do monólogo e solilóquio a fim de mostrar como a forma ajuda na articulação da ideologia da autora. Será focalizada a representação da mulher através dessas narrativas, e como Parker trabalha o humor dentro dessa estrutura.

O terceiro capítulo abordará a questão social da mulher, e sua representatividade dentro do contexto histórico e cultural. Para isso, analisaremos os contos "The Lovely Leave" (1943) e "The Banquet of Crow" (1957), que dialogam com o contexto social externo, e se utilizam do humor para mostrar o condicionamento da mulher na sociedade.

Por fim, é muito importante observar que não foi encontrada, nos registros da Biblioteca da USP, nenhuma tese que tratasse desta autora. Também, somente duas obras referentes a ela foram traduzidas para o português, uma biografia A Extravagante Dorothy Parker, de Dominique de Saint Pern e Big Loira e Outras Histórias de Nova York, seleção de contos traduzidos por Ruy Castro. No entanto, é fato que Dorothy Parker continua sendo atual; sua vida foi o tema do vídeo Dorothy and Alan at Norma Place, de 1987; do filme Mrs Parker and The Vicious Circle, de 1994, além de muitos de seus contos já terem sido adaptados para o teatro por grupos amadores e profissionais. No Brasil, mais recentemente esteve em cartaz seu conto "A valsa" (The Waltz), como um monólogo pertencente à peça "Mulheres por um Fio", com direção de José Possi Neto, e foi realizado um curta-metragem de animação desse mesmo conto, dublado pela atriz Marisa Orth.

Vemos, com isso, que Dorothy Parker permanece sendo um importante expoente da condição das mulheres na sociedade capitalista americana, cujo comportamento influencia os costumes das mulheres nas grandes urbes em todo o mundo. 


\title{
O HUMOR E O CONTO
}

\author{
Qual é a Graça?
}

"O mundo para quem sente é uma tragédia, e para quem pensa, uma comédia."

\section{Machado de Assis}

O Cômico, termo de origem grega, traduz, de forma geral, a reunião de idéias ou de situações aparentemente irreconciliáveis, com a intenção de produzir o riso através de um raciocínio engenhoso. Este pode ser desdobrado em diferentes classificações. O termo wit ${ }^{6}$, por exemplo, pode ser considerado um tipo de texto ácido cujo foco está na personagem e na situação, mais do que nas idéias e nos jogos de palavras. $\mathrm{O}$ humor $^{7}$ se difere do wit, por ser mais imaginativo e menos intelectual. Este também pode ser considerado menos cruel que a sátira; cujo objetivo principal ultrapassa o cômico, possuindo conotações políticas, sociais ou morais. A farsa também se diferencia do humor, pois tem como característica personagens e situações caricatas, e não apresenta preocupação com a verossimilhança nem com o questionamento de valores.

A mensagem irônica, por sua vez, possui uma função quase ética, de transmitir um juízo de valor sobre o "mundo exterior". Trata-se de uma forma de discurso na qual o autor diz algo que na verdade ele não quer dizer e espera que as pessoas entendam não só o que ele quer dizer de verdade, mas também sua atitude em relação ao que diz. Ou seja, a ironia acontece no espaço entre o dito e o não dito.

Para alguns críticos como D.C. Muercke, todo escritor ocupa uma posição irônica.

Isso se dá por diversos motivos: para que possa produzir algo de qualidade, o escritor deve ser ao mesmo tempo criativo e crítico, subjetivo e objetivo, entusiástico e realista, emocional e racional, inconscientemente inspirado e um artista consciente; seu trabalho dá sentido ao mundo e ao mesmo tempo é ficção, ele se sente na obrigação de

\footnotetext{
${ }^{6}$ Não há uma tradução que abranja o significado do wit, mas podemos tentar traduzir por espirituosidade, perspicácia, sagacidade.

${ }^{7}$ De acordo com a célebre "teoria dos humores", atribuída a Hipócrates (séc.V a.C.), havia no corpo humano quatro líquidos ou humores (sangue, bílis negra, bílis amarela e fleuma). Estes estariam relacionados com os quatro órgãos secretores (coração, baço, fígado e cérebro) e com os quatro elementos cósmicos (ar, terra, fogo e água). Era o predomínio de um desses humores que determinaria o temperamento de cada ser humano. LAIN-ENTRALGO, Pedro (Org.). Historia universal de la medicina. Barcelona: Salvat, 1972. p. 61.
} 
fazer um relato verdadeiro e completo da realidade, mesmo sabendo isso ser impossível sendo a realidade incompreensivelmente vasta, cheia de contradições e em constante mudança. (MUERCKE 1970, p. 20). A intenção pode ser então considerada uma das características principais da ironia. Essa, inclusive, é uma das poucas maneiras de distingui-la da mentira.

A ironia, para Palante (apud Minois), é marca das contradições de nossa natureza. Para ele, a ironia não é zombaria: no fundo, leva as coisas a sério, mas dissimula sua ternura. $\mathrm{O}$ autor, entretanto, nega acesso e entendimento à mulher quanto à ironia, "uma vez que esta é considerada marca do intelecto”. (2003, p. 567). Para ele, portanto, a mulher não possui intelecto, e por isso não poderia entender uma ironia.

Com essa opinião, dada por Palante em 1906, percebemos que a ironia pode ser usada como estratégia discursiva, envolvendo relações de poder. Linda Hutcheon, em seu livro Teoria e Política da Ironia, foca sua análise no conceito de que a ironia consegue funcionar e funciona taticamente a serviço de uma vasta gama de posições políticas, legitimando ou solapando uma grande variedade de interesses. Veremos que Dorothy Parker reflete essa vertente, ironizando a causa de sua crítica social.

Também podemos perceber que o significado das ironias muda de época para época, e os objetos de riso são alterados com as mudanças ocorridas nas civilizações. Para Mark Twain, grande expoente do humor norte-americano, uma obra que almejasse permanecer humorística para sempre não deveria ensinar nada abertamente. E frisava que seu "para sempre" deveria ser entendido como trinta anos (apud WHITE, 1941, p. 22). Vladimir Propp também pondera que cada época e cada povo possui seu próprio sentido de humor e de cômico, que muitas vezes é incompreensível ou inacessível em outras épocas. (1992, p. 32).

Para a maioria dos críticos, a ironia cria uma relação especial entre o ironista e o interpretador. Para Linda Hutcheon, entretanto, é a sociedade que possibilita a ocorrência da ironia. Por isso, quanto mais o contexto é compartilhado, menos óbvios serão os marcadores necessários para sinalizá-la. (2000, p. 37)

Em certos casos, a ironia e o humor podem ser combinados, em outros a ironia nada tem a ver com o humor. Um exemplo pode ser a opinião de Palante sobre a falta de intelecto feminino, por transmitir agressividade. Também nem todo humor é irônico, mas tanto o humor quanto a ironia dependem do contexto social e conjuntural para poderem 
existir e para ambos os conceitos o interpretador desempenha importante função, atribuindo sentidos e motivos, numa situação e contexto particulares, para um propósito particular. Para que seja possível a decodificação da mensagem, então, uma mesma ideologia, uma mesma visão de mundo deve ser partilhada.

A existência, na América, de diversidade étnica, religiosa e social com entidades representativas, tem como conseqüência uma forte imposição de obediência às regras, a fim de se manter organizada a sociedade. Dessa maneira, o humor americano é construído simultaneamente com seus objetos de crítica. Porém, ao mesmo tempo em que é estabelecido um humor "politicamente correto", são encorajados os diferentes pontos de vista, de modo a se opor a qualquer fanatismo e proteger o desenvolvimento e a liberdade de expressão.

Aristóteles, na sua Poética, considera a comédia como a imitação de homens inferiores; não quanto a toda espécie de vícios, mas só quanto àquela parte torpe que é o ridículo. Para ele, o cômico consiste, então, em rirmos daquilo que é desagradável ou que tem defeitos. O prazer implícito no humor nasce da sensação de superioridade sobre as pessoas que fazem rir. Deste modo, todo humor seria uma forma de escárnio.

Também para Thomas Hobbes (2002) o riso é fundamentalmente uma estratégia para enfrentar sentimentos de inadequação. Ele diz:

O entusiasmo súbito é a paixão que provoca aqueles trejeitos a que se chama riso. Este é provocado ou por um ato repentino de nós mesmos que nos diverte ou pela visão de alguma coisa deformada em outra pessoa, devido à comparação com a qual subitamente nos aplaudimos a nós mesmos. (p. 62)

Esse tipo de humor pode ser ilustrado ao evocarmos célebres artistas norteamericanos como Charlie Chaplin e os Irmãos Marx, e personagens como O Gordo e o Magro e Os Três Patetas, considerados os maiores expoentes da comédia no cinema dos Estados Unidos. Embora todas as personagens e situações criadas contenham uma dose de crítica às particularidades da sociedade, é devido às suas características "inadequadas", como a tolice, a inabilidade, a coragem inconseqüente, o tipo físico, entre outras, que os tornam passíveis de humor.

Na obra The Art of Laughter o pesquisador Neil Schaeffer criticou as teorias do riso que interpretam o cômico como meramente resultante de um trabalho de deformação da realidade por parte do artista. Ele dirigiu também a sua crítica à teoria que considerou o 
riso uma reação humana a tudo o que apresenta algo de risível. Ele comentou: "Não há nada na natureza que pode ser designado como genuinamente ridículo sem referência à natureza humana que a percebe e dela ri." "(tradução nossa)

Opondo-se a essa perspectiva em que a imaginação tem um papel passivo, o crítico coloca a tônica não na valorização do objeto cômico, mas antes naquele que ri, uma vez que qualquer acontecimento está sempre sujeito a diversas interpretações.

Para Immanuel Kant, o humor surge da combinação de elementos díspares e se alimenta do efeito de surpresa. Este é identificado, freqüentemente, como uma "expectativa frustrada". Kant alegou que o humor consiste na dissolução violenta de uma atitude emocional. Nesta visão, o essencial para o humor é a mistura de duas idéias diferentes. Numa breve passagem de Crítica da Faculdade do Juízo (1790), Kant expôs que o riso é tido como uma espécie de jogo com idéias estéticas que só podem causar o riso pela sua alternância, ou seja, quando rimos é porque jogamos ainda por um tempo com o nosso próprio desacerto em relação a um objeto. Este desacerto deve-se ao fato de que em tudo o que pode suscitar o riso tem de haver algo absurdo, face ao qual o entendimento subitamente cede nesta apresentação em que não encontra o esperado. Ele ponderou: " $\mathrm{O}$ riso provém de uma expectativa que se resolve subitamente em nada" (2005, p. 240)

Podemos verificar essa característica em dois poemas de Dorothy Parker. O primeiro, "Comment", está inserido na coletânea de contos Enough Rope de 1926:

$\mathrm{Oh}$, life is a glorious cycle of song, A medley of extemporanea; And love is a thing that can never go wrong; And I am Marie of Roumania.

Até a terceira frase, a autora conduz o leitor a um raciocínio, tratando poeticamente da vida e do amor. Subitamente, então, na última frase, ela desmente o que vinha sendo postulado, "enganando" o leitor ao afirmar que se aquilo que dissera antes é verdade então que ela é a rainha da Romênia. Essa "quebra" no pensamento produz o humor, assim como podemos observar no poema "Healed", presente na coletânea de contos Sunset Gun de 1928:

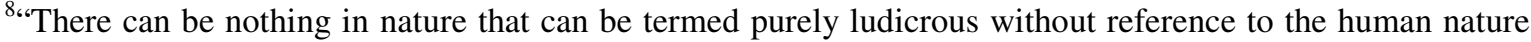
that so perceives and laughs at it" Schaeffer, Neil. The Art of Laughter, Columbia University Press, New York, 1981 p. 5.
} 


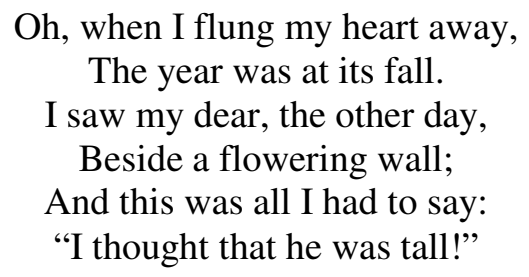

Aqui, também, o leitor é levado a uma linha de pensamento, na qual a personagem expõe seus sentimentos. Se o poema não possuísse um viés cômico, a última linha poderia ser substituída por exemplo por: "I love him more than all!" Se fosse esse o fim do poema, haveria uma maior coerência com o que vinha sendo escrito, mas nenhum humor.

Esses preceitos sobre o humor são retomados por Schopenhauer (1818) que apontou que o riso, fenômeno exclusivamente próprio da natureza humana, resulta da incongruência existente entre uma idéia e o objeto real a que se pretende aplicar essa mesma idéia. Para ele, todo riso é provocado por um paradoxo. Nos contos de Parker analisados nos capítulos seguintes veremos, por meio do percurso das personagens, como se dá esse paradoxo, pois uma vez que as personagens não sofrem nenhuma modificação verdadeira, e terminam igual ou piores do que eram no início, o leitor é surpreendido não com uma proposta de encerrar um raciocínio ou de uma lição moralista, mas com um painel cômico da vida dessas pessoas, presas em suas próprias armadilhas.

No início do século XX, com as descobertas psicanalíticas de Sigmund Freud, o humor também passou a ser visto como uma forma de escape face às inibições e recalcamentos que a sociedade impõe ao indivíduo. Freud (1905) considerou o humor uma forma de enganar a censura, nome que aplicou para as inibições internas que impedem de dar forma aos impulsos naturais. Segundo ele, não somente os impulsos sexuais são reprimidos pela censura, mas também os impulsos maliciosos. Ele proferiu: "(Os chistes) tornam possível a satisfação de um instinto, seja libidinoso ou hostil, face a um obstáculo." (1905, p. 121)

Ao se questionar as exigências sociais convencionais, o riso funcionaria então como um prazer e uma estratégia compensatória, fornecendo o alívio da restrição que impõem essas exigências. Este, porém, pode ser apenas temporário, como quando a tensão é repentinamente removida por meio de gargalhadas, através do trocadilho ou do duplo sentido, por exemplo. 
Neste ponto de vista defendido por Freud, o elemento central do humor não é, portanto, uma sensação de superioridade ou o conhecimento de incongruências, mas sim, o sentimento de alívio provocado pela remoção de barreiras. Esse alívio provém da identificação criada com o leitor. No prefácio de seu livro The Book of Negro Humor (1966), Langston Hughes também se refere ao humor com um tipo de "terapia", mas denota a agressividade inerente a ele. Ele definiu:

"Humor is laughing at what you haven't got when you ought to have it. Of course, you laugh by proxy. You're really laughing at the other guy's lacks, not your own. That's what makes it funnythe fact that you don't know you are laughing at yourself. Humor is when the joke is on you but hits the other fellow first - before it boomerangs. Humor is what you wish in your secret heart were not funny, but it is, and you must laugh. Humor is your own unconscious therapy."

Dessa forma, um comentário cômico só faz sentido quando o leitor se identifica com ele e, ao rir, libera sua própria angústia frente à situação apresentada. Aqui vale salientar o provérbio italiano que diz: "Quello che scherza, si confessa" ("Aquele que graceja, confessa.”)

Seguindo o raciocínio apresentado anteriormente por Vladimir Propp quanto à impossibilidade de uma ironia ou humor universais, por serem específicos à cultura, quando se desafiam as normas de conduta social, seja atacando-as direta ou indiretamente, essa transgressão é ao mesmo tempo a transgressão de ideais coletivos. Percebida como defeito, sua descoberta suscita o riso. Ele completa que nas revoluções sociais, torna-se cômico o que pertence irremediavelmente ao passado e não corresponde às novas normas criadas pela ordem ou regime social que venceu. A presença do passado no presente é sujeita à ridicularização. Assim, a comicidade tem sua base na divergência entre as normas de dois modos sociais de vida historicamente determinados.

No prefácio do livro The Marble Fun escrito no século XIX, Nathaniel Hawthorne apontou para a dificuldade de se escrever um romance sobre um país onde não há nenhuma sombra, nem antiguidade, nem mistérios, nenhum erro pitoresco e lúgubre. Mesmo um

\footnotetext{
${ }^{9}$ Humor é rir daquilo que você não possui quando deveria. Claro, você ri "por procuração". Você está rindo na verdade das deficiências alheias, não das suas próprias. É isso que o torna engraçado - o fato de que você não sabe que está rindo de si mesmo. Humor é quando a piada é sobre você mas atinge primeiro o camarada ao lado - antes de sofrer o efeito bumerangue. Humor é aquilo que você gostaria, no seu íntimo, que não fosse engraçado, mas é, e você deve rir. Humor é a sua própria terapia inconsciente. HUGHES, Langston. The book of negro humor. New York: Dodd, Mead, 1966. Prefácio. (Tradução nossa).
} 
século depois e já possuindo sombras encobertas, uma superfície de comportamento impecável é sempre evidenciada nos Estados Unidos. Os humoristas apontam sua crueldade, então, para o embelezamento exagerado da vida americana, na tentativa de reparar essa realidade. Os extremos dessa crueldade podem ser observados no chamado Humor Negro.

O humor não deve ofender nem ferir ninguém, independente de qual assunto ele trate. Isso porque, para ser engraçado, pressupõe-se a existência de um erro, um desvio que é aceito por não ser ameaçador. Desse modo, pode-se fazer piada sobre sexo, religião, sobre a morte e outros assuntos considerados impróprios ou polêmicos.

Este tipo de humor pode ser visto em larga escala no Humor Judaico, que obteve particular sucesso nos Estados Unidos. O "politicamente incorreto" produz surpresa, ao violar regras de comportamento sem parecer, ao ajudar a tornar próprio aquilo que é impróprio, ao tornar agradável o desagradável e ao apresentar uma contradição, por conter ao mesmo tempo o prazer e o horrível, chamado de grotesco. O problema desse tipo de humor é que ele invariavelmente ofende àqueles que não o compreendem.

Um exemplo desse tipo de humor pode ser verificado no famoso poema "Résumé" da coletânea Enough Rope de 1926 de Dorothy Parker:

Razors pain you;

Rivers are damp;

Acids stain you;

And drugs cause cramp.

Guns aren't lawful;

Nooses give;

Gas smells awful;

You might as well live

Ao tratar dos perigos e malefícios ocasionados pelas formas mais conhecidas de suicídio, a autora chega à conclusão de que então é melhor continuar vivendo. A morte, tema trágico e lúgubre, se torna passível de humor.

Diante das diversas teorias sobre a comicidade, não é surpreendente que, por vezes, um mesmo autor exiba um posicionamento teórico misto, avançando com elementos pertencentes às outras teorias. É o caso do filósofo francês Henri Bergson, que realizou um dos mais aprofundados estudos sobre o cômico. 
$\mathrm{Na}$ sua obra $O$ Riso $^{10}$ encontram-se reunidos três artigos de fundamental importância para a compreensão dos mecanismos da comicidade.

O autor define que uma situação é sempre cômica quando ao mesmo tempo pertence a duas séries de acontecimentos absolutamente independentes e pode ser interpretada em dois sentidos diferentes. Do mesmo modo que Kant, Bergson falou então de um movimento pendular do nosso espírito entre duas interpretações opostas, daí a necessidade de se chamar a atenção do leitor para estes dois fatores: a independência e a coincidência. Bergson também salientou, retomando Schopenhauer, que o cômico é um fenômeno exclusivamente humano, destacando ainda que este remete à inteligência. De acordo com esta teoria, as emoções seriam um obstáculo à produção do riso. Ele ponderou:

A comicidade dirige-se à inteligência pura; o riso é incompatível com a emoção. Descreva-se um defeito que seja o mais leve possível: se me for apresentado de tal maneira que desperte minha simpatia, ou meu medo, ou minha piedade, pronto, já não consigo rir dele. (2004, p. 4)

Seria, desta maneira, necessário um distanciamento, uma "anestesia momentânea do coração" para que o cômico produzisse o seu efeito.

Bergson também falou sobre um movimento de relaxamento que há no riso, ele defende que o obsurdo cômico nos dá a impressão de um jogo de idéias, e nosso primeiro movimento é associar-nos a esse jogo, nos poupando da fadiga de pensar, e de viver. Mas só descansamos um instante, pois o riso é acima de tudo uma correção, e não pode ser associado somente ao prazer.

Muito freqüentemente, o riso aparece associado a uma função didática, cumprindo a máxima latina "Ridendo castigat mores" "É com o riso que se corrigem os costumes". Para tanto, podemos apontar a sátira, a ironia, o humor, a caricatura, o pastiche, a paródia, entre outros, como meios de se atingir este propósito.

No livro A História do Riso e do Escárnio (2003), de Georges Minois, o pesquisador Howard Bloch confirmou: "... o riso é um fenômeno liminar, um produto das soleiras, (...) o riso está a cavalo sobre uma dupla verdade. Serve ao mesmo tempo para afirmar e para subverter". (BLOCH apud MINOIS)

\footnotetext{
${ }^{10}$ Sempre que nos referirmos à obra O Riso, será a edição São Paulo: Martins Fontes, 2004.
} 
É também importante ressaltar que, por todo tipo de humor possuir um alcance cultural, nos é possível através dele, tentar definir, explicar e aumentar nosso entendimento quanto a uma determinada cultura em particular.

Para Antônio Cândido, uma grande obra surge na confluência da iniciativa individual e das condições sociais. (1965, p. 30). Ele argumentou: “O escritor, numa determinada sociedade, é não apenas o indivíduo capaz de exprimir sua originalidade (que o delimita e especifica entre todos), mas alguém desempenhando um papel social." Esse significado social é alcançado, então, na medida em que as pessoas correspondem a necessidades coletivas; e estas, agindo, permitem que os indivíduos possam exprimir-se, encontrando repercussão no grupo. (1965, p. 88) No caso de Dorothy Parker, como veremos a seguir, é o humor que lhe permite agir na sociedade, e, ao encontrar repercussão das situações narradas no público que pretende atingir, tem o objetivo de mudar a realidade.

Para a análise dos contos nos capítulos seguintes, nos apoiaremos mais diretamente nos postulados sobre a comicidade de Bergson, por consistir em um amplo estudo que abrange outras teorias e, principalmente, por se basear na idéia de que o riso possui um propósito, visando o aperfeiçoamento do Homem. Segundo ele, o riso deve preencher certas exigências da vida em comum, ou seja, deve ter um significado social. (2004, p. 6) E é só porque o cômico pode assumir uma dimensão social que pode cumprir uma função didática associada à correção dos costumes, considerados por Dorothy Parker ultrapassados e limitadores da existência feminina.

\section{A Tradição Masculina e o Humor Feminino}

"It's a very serious thing to be a funny woman."

Frances Whitcher

A boa literatura de um país tem o dever de expressar o caráter nacional. No início, contudo, a literatura norte-americana apresentava um caráter híbrido europeu, uma vez que os escritores americanos foram produtos de influências européias. No século XIX, o conto se firma como gênero e nos anos 1830, designa não somente uma história curta, mas uma categoria literária independente, com características próprias. Ela é definida, usualmente, 
como uma narrativa que oferece uma amostra da vida, por meio de um episódio, um flagrante, um momento singular e representativo. Constitui-se de uma história simples, curta, com economia de meios e concentração da ação, do tempo e do espaço.

O primeiro contista americano de real importância surge no começo do século XIX. Washington Irving considerava o conto uma tela na qual seus temas eram esboçados. Diferentemente de Aristóteles em sua Poética, Irving deu maior ênfase ao tema do que à ação, valorizando a personagem.

Neste século, os grandes contistas são do sexo masculino. Outro nome de destaque é Herman Melville, que parece antecipar o naturalismo ao retratar, com ironia, mulheres vítimas da mecanização, que trabalham em uma fábrica de papel. Outro escritor que se faz representativo em contos e romances é Nathaniel Hawthorne, que se interessa pelo problema do bem e do mal, ambientando suas histórias na Nova Inglaterra.

Com a marcha para o Oeste, a fronteira começa a influenciar a escrita americana. Nesse cenário, um autor nascido no oeste, Samuel Langhorne Clemens, mais conhecido por seu pseudônimo Mark Twain se mostra como um dos mais significativos também trabalhando com contos e romances. A ironia de seus escritos pode ser observada nessa breve passagem de seu romance Adventures of Huckleberry Finn, no capítulo XXXII:

"We been expecting you a couple of days and more. What's kep'you? boat get around?"

"Yes'm - [but] it warn't the grounding - that didn't keep us back but a litle. We blowed out a cylinder-head."

"Good gracuious! Anyboby hurt?"

"No'm. Killed a nigger."

"Well, it's lucky; because sometimes people get hurt."

Ao ignorar a morte de um negro como uma perda, a ironia é imbuída de uma forte crítica ao preconceito. Juntamente com Twain, podemos destacar também Henry James e Wiliam Dean Howels, como os escritores mais representativos do fim do século XIX.

Nessa mesma época, o norte-americano Edgard Allan Poe teceu o que se considera a primeira "teoria do conto", ao comentar criticamente o livro Twice Told Tales de Nathaniel Hawthorne. Poe transpôs A Poética para o conto, fazendo do personagem um complemento da ação e considerando cada elemento da história subordinado a ela. Para ele, a eficácia de um conto depende de seu efeito, sua intensidade como acontecimento puro, isto é, todo comentário ao acontecimento em si deve ser radicalmente suprimido. 
Com uma idéia de efeito pré-concebido, essas histórias compactas e cheias de tensão caracterizam o conto moderno. Em seu livro Valise de Cronópio (1974), no qual disserta sobre a teoria de Poe, Julio Cortázar defendeu que o conto parte da noção de limite, tanto físico, no que se refere ao espaço em que a história se passa, como ao limitar uma situação ou acontecimento que seja significativo. $\mathrm{O}$ escritor passa a expor sua história ao invés de explicar, narrar ou relatar a ação.

Brander Matthews em The Philosophy of the Short Story também proferiu que um conto é algo diferente de uma história que é simplesmente curta. Ele compara o conto ao romance e defende que ele do romance se difere principalmente por sua essência, por possuir uma unidade de pensamento que o romance não possui, mostrando uma ação, em um lugar, em um dia, lidando com um único personagem, um evento específico, uma determinada emoção ou uma série de emoções derivadas de uma única situação. (1931, p. 52)

Apesar da predominância masculina neste tipo de literatura, desde 1840 as mulheres têm como meio de expressar suas observações humorísticas os jornais ou colunas de revistas. Nos anos 1840 e 1850, Frances Whitcher escrevia contos para o Neal's Saturday Gazette e o Godey's Lady's Book, e Anna Cora Mowatt foi uma das primeiras mulheres a ter sucesso como dramaturga. Sua primeira peça, Fashion, foi elogiada pelo público e pela crítica especializada. Também atriz, ela não dependia financeiramente de seu marido, mas era adepta dos valores convencionais da classe média, não vendo com bons olhos os movimentos em favor das mulheres.

A relativa liberdade das mulheres de fazerem humor estava diretamente relacionada à sua posição na sociedade. Conforme seu espaço era conquistado, as restrições eram aos poucos reduzidas. O humor feminino pode, então, ser considerado um guia para o conhecimento das regras e valores da época, e em particular das relações estabelecidas pelas mulheres com a realidade cultural americana. Para a crítica Nancy Walker, ser uma mulher humorista na América trazia questões sérias como o conflito entre o intelecto e a feminilidade, a questão de serem consideradas uma minoria e o poder transformador de uma visão feminista.

Zora Neale Hurston é outro nome de destaque nesse panorama de mulheres que escreviam humor. Além de mulher, Zora era negra e usava a ironia em suas histórias sobre a cultura negra do sul dos Estados Unidos como ferramenta de combate ao racismo. Nas críticas contemporâneas aos seus escritos, podemos perceber que não era proibido às 
mulheres escreverem poemas, romances, peças e contos, mas para que isso fosse "aceito", seria necessário romper com a posição de subordinação imposta há séculos pela tradição patriarcal. Esse preconceito tão arraigado pode ser observado em frases como: "Hurston's humor was enjoyed, but found suspect, partially because it was `unladylike'” (WALKER, 1988, p. 113)

$\mathrm{Na}$ virada do século, a rápida urbanização da sociedade americana e o crescente número de mulheres adotando carreiras, abrindo um caminho de escolhas e liberdade levou ao desenvolvimento do ponto de vista feminino. No século vinte, as inovações tecnológicas, médicas, sociais, ideológicas e políticas, assim como a conquista de direitos políticos e a descoberta de novas técnicas de controle da natalidade tornaram as mulheres mais independentes. O otimismo progressista e a busca por avanços e mudanças do século XIX foram aos poucos substituídos pela dúvida e confusão de uma cultura urbana e burocrática.

Os escritores americanos seguem as mudanças na sociedade alterando sua sátira social aberta para estudos introspectivos sobre o indivíduo e suas relações. A ênfase no narrador irônico que comenta as fraquezas dos outros também vai sendo substituída pelo narrador que personifica essas mesmas fraquezas. A observação passa para a ação.

O naturalismo possui grande influência na literatura americana. Primeiramente como tentativa de representar na ficção as teorias deterministas que se desenvolviam na filosofia, na psicologia, etc., os naturalistas procuraram também denunciar as injustiças sociais. Tratava-se do começo de uma consciência na qual o homem não é apenas influenciado pelo meio ou por forças hereditárias, mas é um produto delas. Essa maneira de pensar proporcionou à ficção a exploração de novos temas e novas técnicas, como o documentário, os fragmentos da vida, o monólogo interior, o impressionismo, o expressionismo e até mesmo o simbolismo.

Os grandes escritores que se seguiram foram, cada um ao seu modo, influenciados por esse naturalismo, como, por exemplo, Erskine Caldwell, Theodore Dreiser, Sherwood Anderson, entre outros. Para alguns autores, porém, o naturalismo apenas desviou para o meio social a ênfase nos antigos fatos da vida com os quais o homem sempre se defrontou - a morte, a dor, a loucura, a catástrofe e o mal. A sociedade tornou-se, então, o novo inimigo a ser superado. Já pode ser visto nesse tipo de literatura os prenúncios da filosofia e literatura existencialista. Escritores como Ernest Hemingway, F. Scott Fitzgerald e 
Wiliam Faulkner se fazem extremamente significativos, assim como a autora objeto de nosso estudo.

Em Dorothy Parker, o elemento naturalista se exprime pela propagação da monotonia social na qual vivem seus personagens, sem poderem dela escapar.

Assim como várias de suas antecessoras, Dorothy Parker escreveu contos de humor para as revistas Vanity Fair e The New Yorker, e posteriormente teve seus escritos publicados em antologia de contos.

Para a escritora, não haveria meio mais eficaz de se fazer crítica do que o humor. Ela comentou:

Humor to me, Heaven help me, takes in many things. There must be courage; there must be no awe. There must be criticism, for humor, to my mind, is encapsulated in criticism. There must be a disciplined eye and a wild mind. There must be some lagniappe in the fact that the humorist has read something written before 1918. (apud PERELMAN, p. xixiv)" $" 11$

Porém, Parker não quer ser classificada pejorativamente como humorista. Sua preocupação em criticar e retratar não só uma época, mas um comportamento mais amplo e universal pode ser verificada na sua entrevista para Marion Capron em 1958:

I don't want to be classed as a humorist. It makes me feel guilty. I've never read a good tough quotable female humorist, and I never was one myself. I couldn't do it. A "smartcracker" they called me, and that makes me sick and unhappy. There's a hell of a distance between wisecracking and wit. Wit has truth in it; wisecracking is simply calisthenics with words. I didn't mind so much when they were good, but for a long time anything that was called a crack was attributed to me. (CAPRON, 1957, p. 72$)^{12}$

Vemos que a autora nega essa leitura superficial da sua obra, como se esta funcionasse somente como uma piada indelicada. Seu humor não está diluído na temática

\footnotetext{
${ }^{11 "}$ O Humor para mim, Deus me ajude, se dá de diversas formas. Precisa ter coragem, não pode haver temor. Deve haver crítica, para mim, o humor está encapsulado em crítica. Deve haver um olho disciplinado e uma mente selvagem. Tem que haver alguma recompensa pelo fato de um humorista ter lido algo escrito de antes de 1918. (Tradução nossa).

${ }^{12 ، " E u ~ n a ̃ o ~ q u e r o ~ s e r ~ c l a s s i f i c a d a ~ c o m o ~ h u m o r i s t a . ~ I s s o ~ m e ~ f a z ~ s e n t i r ~ c u l p a . ~ E u ~ n u n c a ~ l i ~ u m a ~ u m a ~ b o a ~ c i t a c ̧ a ̃ o ~}$ de uma humorista mulher, e nem fui eu uma delas. Eu não podia fazê-lo. "piadista espirituosa", eles me chamam, e isso me deixa doente e infeliz. Existe uma grande distância entre ser uma piadista com sagacidade e ser sagaz. Há verdade contida na sagacidade, enquanto piadista espirituosa é simplesmente calistênico com as palavras. Eu não me importava tanto quando as piadas eram boas, mas por um longo tempo, qualquer coisa considerada uma piada era atribuida a mim.” (Tradução nossa.)
} 
de suas histórias, e é por meio dele que são construídos estereótipos para em seguida serem subvertidos. Um exemplo disso é o uso da sátira, um modo de crítica dotado de seriedade e longevidade, como ferramenta. Ela comentou:

[But] ah, satire. That's another matter. They're the big boys. If I'd been called a satirist there'd be no living with me. But by satirist I mean those boys in the other centuries. The people we call satirists now are those who make cracks at topical topics and consider themselves satirists creatures like George S. Kaufman and such who don't even know what satire is. Lord knows, a writer should know his times, but not show them in wisecracks. Their stuff is not satire; it's as dull as yesterday's newspaper. Successful satire has got to be pretty good the day after tomorrow. (CAPRON, 1957, p. 74)

A sátira é considerada, na época, um gênero totalmente masculino, por isso a autora se refere aos escritores como "os grandes garotos". Para o crítico Charles Knight, o que torna a sátira mais ou menos masculina não é uma exclusividade de gênero (sátira e tragédia para homens e comédia e lírica para as mulheres), mas o fato de as mulheres serem tratadas como um grupo identificável, enquanto que por homens se entende a raça humana. A sátira dos homens é, portanto, a sátira da natureza humana, enquanto a sátira de mulheres é considerada a sátira de um grupo particular, como se esta também não fosse universal. (2004, p. 6)

As personagens femininas de Dorothy Parker expressam suas inseguranças sobre sua aparência e suas habilidades. E a sátira feita através de suas personagens humorísticas se dá exatamente pelo espelhamento das inseguranças da classe média americana que aspira a sofisticação, intimidada pelos novos modos de pensar e de viver.

Para Antônio Cândido, o artista, sob o impulso de uma necessidade interior, é orientado segundo os padrões da sua época, escolhe certos temas, usa certas formas e a síntese resultante age sobre o meio. (1965, p. 25). Neste caso, Dorothy Parker, com o objetivo de provocar o leitor à reflexão, considerando a sociedade patriarcal, escolheu a temática da dependência feminina, e a tratou pelo viés do humor, da sátira e utilizou como gênero literário o conto, a fim de se tornar agente no seu meio e dialogar com seus leitores através de suas personagens, típicas figuras femininas do século XX.

\footnotetext{
13،“(Mas) Ah, a sátira. Esse é outro assunto. Aí estão os grandes garotos. Mas por sátira eu quero dizer aqueles garotos dos outros séculos. As pessoas que chamamos de satiristas hoje são aquelas que fazem estrondo com tópicos locais e consideram a si mesmos satiristas - criaturas como George S. Kaufman e outros que nem sabem o significado de sátira. Deus sabe, um escritor deveria conhecer sua época, mas não mostrá-la em piadas espirituosas. O que eles fazem não é sátira; é tão enfadonho quanto o jornal do dia anterior. A sátira de sucesso tem que ser de muito valor para os dias que seguem." (Tradução nossa).
} 
O maior exemplo dessa "figura feminina" do século XX, dependente e fútil, talvez seja a personagem Lorelai Lee do livro Os Homens Preferem as Loiras, de Anita Loo. Escrito em 1925, a personagem pode ser considerada o estereótipo da "loira burra". Assim como Lorelai, Hazel Morse, a protagonista do conto "Big Blonde" de Parker é um estereótipo. Na história de Parker, porém, a personagem é ainda mais claramente vítima das conjecturas sociais acerca dos valores femininos.

A história abre com a seguinte narrativa:

Hazel Morse was a large, fair woman of the type that incites some men when they use the word "blonde" to click their tongues and wag their heads roguishly. She prided herself upon her small feet and suffered for her vanity, boxing them in snub-toed, high-heeled slippers of the shortest bearable size. The curious things about her were her hands, strange terminations to the flabby white arms splattered with pale tan spotslong, quivering hands with deep and convex nails. She should not have disfigured them with little jewels. (p. 105)

Hazel Morse era uma mulher alta e clara, do tipo que provoca nos homens línguas para fora e rabinhos abanando, quando eles pronunciam a palavra "loira". Ela se orgulhava de seus pezinhos minúsculos e sofria com sua vaidade, calçando os sapatos de salto alto, do menor tamanho possível, que lhe espremiam os dedos. O curioso sobre ela eram sua mãos, estranhos terminais de um par de braços flácidos e cheios de pintas - mãos longas e trêmulas, com unhas longas e convexas. Ela não as desfiguraria com anéis ou outras bugigangas. (p. 87)

A autora escolhe contar a história na terceira pessoa, e por possuir um narrador irônico, o distanciamento criado permite que a personagem seja descrita, criticada e que ao mesmo tempo possamos ver suas reações, sua "voz". Os homens também são ridicularizados, uma vez que são descritos como seres maliciosos, estalando a língua e balançando a cabeça em aprovação. O narrador continua:

Men liked her, and she took it for granted that the liking of many men was a desirable thing. Popularity seemed to her to be worth all the work that had to be put into its achievement. Men liked you because you were fun, and when they liked you they took you out, and there you were. So, and successfully, she was fun. She was a good sport. Men like a good sport. (p. 105)

Os homens gostavam dela, e ela descobriu que era gostoso ser gostada por muitos homens. Ser querida parecia-lhe valer todo o esforço que isso pudesse custar. Os homens gostam de você quando você é divertida e, se gostam, a vida é ótima. E com isso, ela se deu bem. Os homens gostam de mulheres que se dão bem na vida. (p. 88) 
Hazel se esforça para se enquadrar no molde ao qual foi designada. A personagem é apresentada como fruto do condicionamento social, e podemos perceber sua visão limitada, pois ao invés de ser educada para ser independente, tanto Hazel quanto Lorelai de $O s$ homens Preferem as Loiras são ensinadas a agradar os homens.

Quando Hazel se sente deprimida, é imediatamente repudiada. Só interessa a seus companheiros o que ela pode lhes oferecer. Vemos isso claramente no diálogo com Ed, o segundo homem que ela passa a querer agradar: "Hey, listen," He would say, "I got worries of my own, and plenty. Nobody wants to hear other people's troubles, sweetie. What you got to do, you got to be a good sport and forget it. See? Well, slip us a little smile, then. That's my girl.” (p. 115) ( - Olhe, escute aqui - ele dizia. - Já tenho bastante problemas, e chega. Ninguém agüenta os problemas dos outros, queridinha. O que você tem que fazer é ser legal e estamos conversados. Que tal agora um belo sorriso? É assim, que eu gosto, garota.) (p. 103) Mesmo sem questionar essas considerações e se esforçando ao máximo para ser querida, ela não consegue afugentar a melancolia, acentuada pelas altas doses de álcool que aprende a ingerir. Em seguida o narrador comenta: “...she wanted the privilege of occasional admitted sadness." (“...queria ter o direito de uma ou outra tristeza admitida"). Mas esse "privilégio" não seria a ela concedido. Por nunca tomar as rédeas de sua própria vida e se submeter sempre às vontades do homem da vez, a depressão se alarga e nem a morte, que lhe parece tentadora a certa altura, ela é capaz de alcançar. Está presa para sempre nessa situação, que não foi criada por ela, mas que ajuda a perpetuar.

Por trás das confusões irônicas de Hazel, assim como dos erros gramaticais cômicos de Lorelai, é encontrada, então, a mesma importante mensagem: a negação do intelecto leva diretamente à sua exploração.

No meio do século XX, o local que abriga o humor feminino é transferido do apartamento urbano usado para encontros, para a casa nos subúrbios, e o ideal da figura feminina não intelectualizada deixa de tentar agradar aos homens com atrativos sexuais para mostrar suas habilidades como dona de casa.

No humor que aflora após a Segunda Guerra Mundial, as mulheres são raramente retratadas como objetos sexuais. O poder da atração continua sendo considerado uma virtude, mas é mais acentuada a luta para se cumprir as monótonas tarefas diárias envolvendo o cuidado com a casa e a educação dos filhos, afinal, os maridos estão de volta da Guerra e querem dedicação. Mais uma vez, a dificuldade e inabilidade de se enquadrar 
num padrão culturalmente estabelecido é fortemente discutida. A condição de "ser pensante" ainda não é concedida à mulher, mas o "fazer" toma o lugar do simples "ser". Ao identificarmos nas histórias os resultados das rígidas expectativas quanto ao comportamento dessas mulheres, percebemos o vazio de suas vidas.

No decorrer do século XX, uma consciência coletiva feminina com problemas e interesses comuns é formada, e o humor feminista surge sendo confundido com o humor feminino, pois apesar de este não denunciar abertamente a descriminação ou reivindicar os direitos das mulheres, nem colocá-las em posições de poder invertendo os valores estabelecidos, ele naturalmente fala da condição imposta ao sexo feminino e das possibilidades de mudança. Os escritos feministas, porém, se diferenciam dos escritos femininos, uma vez que os primeiros criticam um sistema que pode e deve ser mudado, e lutam abertamente para vencê-lo. Já os escritos femininos criticam esse mesmo sistema, mas por meio da constatação da opressão, ou seja, de sua denúncia passiva.

Em 1956, em entrevista para Marion Capron, Parker se declara como sempre tendo sido uma feminista: "Eu sou uma feminista, e Deus sabe que sou fiel ao meu sexo, e você deve lembrar de que desde o princípio, quando essa cidade não estava salva de búfalos, eu lutava por direitos iguais para a mulher." ${ }^{\prime 4}$ (tradução nossa)

Sua luta para que mulheres e homens tenham direitos iguais, porém, não é aberta, o que não caracterizaria sua obra como feminista. Veremos na análise de seus contos nos capítulos seguintes que seus escritos se enquadram na categoria da contemplação dos valores patriarcais, na crítica pela afirmação, pela acomodação de suas personagens e pelo humor indolente.

Para Cortázar, um conto significativo deve ser capaz de atuar no leitor como uma espécie de abertura, de fermento que projete a inteligência e a sensibilidade em direção a algo que vai muito além do argumento literário. A história deve, portanto, quebrar seus próprios limites iluminando bruscamente algo que vai muito além da pequena história que conta. (1974, p. 153)

Segundo ele, ao contrário do romance, que possui conflitos alternados, o contista, por não poder se estender demais, trabalha com a profundidade e possui como seu elemento principal o tema trabalhado. Por ser breve, deve prender a atenção do leitor,

\footnotetext{
14،'I'm a feminist, and God knows I'm loyal to my sex, and you must remember that from my early days, when this city was scarcely safe from buffaloes, I was in the struggle for equal rights for women." CAPRON, Marion. op. cit.
} 
isolando-o de tudo o que o rodeia para depois, terminado o conto, devolvê-lo à realidade de uma maneira enriquecida, mais profunda, e mais bela. Para isso, é necessário um estilo baseado na tensão, na qual os elementos se ajustem de forma única e original.

Num ensaio intitulado "Teses sobre o Conto" do livro Formas Breves, o argentino Ricardo Piglia formulou teses recentes sobre o conto, avançando com as teorias de Poe e Cortázar. Partindo do princípio de que um conto lida sempre com duas histórias, uma exposta e outra velada, e de que o efeito surpresa se produz quando o final da história secreta aparece na superfície, a força de um texto residiria em grande parte no subtexto que o autor é capaz de gerar.

Em Parker veremos que a crítica que faz por meio de seus textos pode ser percebida de duas maneiras. A primeira é uma crítica, por meio do humor, ao papel no qual a sociedade insere a mulher. A segunda, velada, se trata da crítica de como a mulher se coloca na sociedade, acatando sem questionamento os valores impostos.

Isso é o que distingue, para Piglia, um conto bem realizado, a capacidade de tornálo uma experiência única capaz de revelar as verdades que se encontram por trás da vida superficialmente exposta. Para ele, a versão moderna do conto também abandona a estrutura fechada e o final surpreendente, pois a tensão entre as duas histórias contadas nunca é resolvida, sendo a história secreta contada cada vez mais evasivamente, acabando por fundir-se com a história aparente. Seu final imprevisível é ao mesmo tempo inevitável e é essa circularidade que permite ao conto ser uma revelação contínua.

Nas histórias escritas por Dorothy Parker analisadas nos capítulos seguintes, além de verificarmos as situações de tensão propostas pela autora e seu modo único de lidar com elas, observaremos como são mostrados os dramas femininos e as relações de poder entre os sexos, tratando de estereótipos familiares para zombar deles, mostrar sua irracionalidade e até o seu perigo. Veremos que uma constante em suas histórias é justamente a não surpresa existente no clímax, sendo a verdadeira surpresa e modernidade de seus escritos residente no fato de que, no fim, nada é verdadeiramente alterado. Dessa forma, a autora pretende alcançar um efeito certeiro: a assimilação pelo leitor do subtexto, tão escondido quanto claro, com o objetivo de provocar uma subversão dos costumes e uma tentativa de "correção" social.

Com isso, apontaremos que, apesar do humor utilizado afirmar ou denunciar aquilo que é potencialmente risível em suas narrativas, este não é forçosamente alegre, tornandose decerto uma arma literária vigorosa contra as regras impostas pela sociedade às mulheres da época. 


\section{A MULHER E O IMAginÁRIO}

"Se queres ser universal, fala da tua aldeia."

Tolstói

Nos anos 1920, a atividade do espetáculo ignorava os tempos difíceis e criava uma geração espontânea de salas que se multiplicavam. O poder do teatro não era abalado nem pelo rádio, nem pela televisão, e suas possibilidades se mostravam ilimitadas. Em 1921, a Broadway tinha setenta e seis salas de teatro clássico, sem contar as especializadas no burlesco e nas comédias musicais. As companhias de cinema ainda não haviam migrado e o mundo da literatura estava em processo de fusão com o do teatro. Os modernos meios de comunicação como os cartoons, as colunas jornalísticas e as revistas de variedades difundiam largamente o humor e a ironia.

É nessa década que o direito do voto às mulheres foi outorgado, resgatando a autoestima, a independência e concedendo papel público à metade da nação americana. As senhoritas já podiam sair sozinhas, experimentar álcool, tabaco, jogo de cartas e o amor livre. Em público, homens e mulheres começavam a discutir francamente a sexualidade. A sociedade fechava os olhos às ligações extraconjugais e a vanguarda sonhava com o "divórcio" sem risco de se expor à opinião pública.

A literatura desse período trazia, então, como substituto à moralidade tradicional, uma maior atenção ao "eu", indo de encontro ao senso de responsabilidade social. Umas das razões pela qual a política, a economia e a idéia de um código social não interessavam muito aos escritores dessa década é a preocupação com a natureza do ser humano, separado da sociedade. O clamor que surgia contra as convenções passava a fazer parte da expressão da necessidade de se atingir um senso individual de culpa, e de determinada maneira se experienciar o mal. Se observarmos bem, podemos perceber essa aura "macabra" contida nos títulos dos livros de Dorothy Parker, em suas coletâneas de poemas e contos, como Enough Rope, Sunset Gun, Death and Taxes, Here Lies e Laments for the Living.

Para o crítico Frederick J. Hoffman (1965), nessa época a moralidade passou a ser muito complexa e uma responsabilidade íntima e pessoal, o que permitia considerar que a salvação não seria rapidamente ou facilmente alcançada. A auto-consciência da escrita 
moderna era representada muitas vezes como ridícula, mas não devido ao seu pessimismo, mas à sua distorção das personalidades. As personagens, dessa forma, eram geralmente grotescas, e suas ações não possuuiam uma consistência racional, o que tornava suas vidas circulares.

Estes foram anos, também, nos quais a realização pessoal começou a ser atrelada ao consumo e as grandes celebridades foram construídas, assim como o interesse pela vida privada das mesmas. $\mathrm{O}$ culto às celebridades foi gerado por Hollywood e tablóides como Photoplay promoviam conselhos de beleza e saúde, assim como tours nas casas dos artistas e muita fofoca sobre suas vidas. Veremos, com isso, que o texto de Parker nasce dessa interface com o mercado, tornando-se extremamente popular.

Nessa produção cultural moderna, um lugar de grande destaque foi ocupado pelo Algonquin Round Table. Para a crítica Nina Miller, o grupo fornece um retrato rigoroso da escrita como construção do ser humano num contexto público de desejo. (1999, p. 88)

Sua freqüência teve variações ao longo dos vinte anos de existência, porém, inquestionavelmente masculino, um grupo central e inalterado comandava a maior parte das conversas. Eram eles o colunista Franklin Pierce Adams (conhecido por F.P.A), os dramaturgos George Kaufman, Donald Ogden Stuart e Alexander Woollcott, o crítico, colunista e escritor Robert Banchley; Harold Ross, editor e fundador da revista The New Yorker e a escritora Dorothy Parker. Parker era a única mulher presente nessa elite. Algumas outras representantes do sexo feminino como a novelista Edna Ferber e a colunista e dramaturga Alice Duer Miller fizeram parte do grupo, mas de maneira periférica à ação, não obtendo a importância e representatividade de Parker. Sua rapidez de raciocínio e excelência para o duplo sentido a transformaram em imbatível adversária num jogo, em voga no momento, de associação de palavras. Desafiada a usar a palavra "horticulture", ela dispara: "You may lead a whore to culture, but you can't make her think." Logo, suas tiradas, batizadas rapidamente de "parkerisms", percorrem o país e Parker ganha, em poucos meses, a reputação de "the wittiest woman in America".

A influência que o grupo exerceu na literatura americana, no teatro e no humor foi ativa e intensa, uma vez que propôs mudanças nas relações entre etnicidade e identidade nacional. A combinação de etnicidade e humor esteve em voga durante muitos anos, como por exemplo no humor judaico, no vaudeville e em alguns sucessos da Broadway como a peça “Abie’s Irish Rose” que esteve em cartaz por cinco anos. Essa combinação, porém, já começava a perder espaço para a transcendência social. Reverberando não somente na elite 
de Nova York, a espirituosidade dos Algonquinos representava uma promessa de uma nova democracia na cultura nacional, na qual esta substituiria a diferença de classes e que tinha na sofisticação sua primeira expressão.

Muitos dos participantes do grupo eram judeus. Parker, por sua vez, era filha de pai judeu e mãe católica, sendo criada como tal. Essa atmosfera do humor judaico fazia parte em muito do estilo Round Table e a heterogeneidade educacional, regional e de classe do grupo reforçaram sua característica democrática.

Para Nina Miller, o Algonquin Round Table tornou-se um produto, uma nascente, a personificação da modernidade popular norte-americana, pois por meio do humor, extremamente vendável numa cultura de sofisticação ainda tímida, era dada a seus participantes a oportunidade de serem inteligentes e espirituosos sem a implicação do intelectualismo, uma vez que o intelectualismo era contraditório à sofisticação. Podiam também ser críticos sem a necessidade de se afiliarem a algum modelo ideológico, e irônicos em relação a si próprios. (1999, p. 90)

Parker desenvolveu suas habilidades humorísticas nas reuniões do grupo e refinou o que viria a ser seu principal tema: o amor. $\mathrm{O}$ amor moderno pode não almejar a atenção masculina ou o casamento, mas também não oferece alternativas positivas para esse amor romântico que critica, uma vez que sua visão das relações heterossexuais é estática e, ao mesmo tempo, circular. Uma possibilidade de mudança para essa dinâmica de dominação e submissão feminina é apresentada, então, quando suas personagens femininas são identificadas e compreendidas por suas iguais.

No poema "Now at Liberty", a autora combina o lirismo tradicional da poesia de amor com o cinismo do amor moderno:

Little white love, your way you've taken;

Now I am left alone, alone.

Little white love, my heart's forsaken.

(Whom shall I get by telephone?)

Well do I know there's no returning;

Once you go out, it's done, it's done.

All of my days are gray with yearning.

(Nevertheless, a girl needs fun.)

Little white love, perplexed and weary, Sadly your banner fluttered down.

Sullen the days, and dreary, dreary. (Which of the boys is still in town?)

Radiant and sure, you came a-flying;

Puzzled, you left on lagging feet.

Slow in my breast, my heart is dying. 
(Nevertheless, a girl must eat.)

Little white love, I hailed you gladly;

Now I must wave you out of sight.

Ah, but you used me badly, badly.

(Who'd like to take me out tonight?)

All of the blundering words I've spoken,

Little white love, forgive, forgive.

Once you went out, my heart fell, broken.

(Nevertheless, a girl must live)

Nesse poema, de 1926, podemos perceber a voz dupla, uma aparentemente honesta, franca; e outra, um aparte para o público, evidenciado não somente pela mudança da linha de discurso, como pelo uso de parênteses, opondo o lirismo exagerado à sofisticação cortês.

$\mathrm{Na}$ primeira voz, podemos perceber a atemporalidade e também a ausência do namorado/amante, mostrando o amor como um estado solitário, tema da dita poesia de amor feminina. Os apartes, porém, se aproveitam das rimas das linhas poéticas e se afirmam como um outro registro da mesma voz, tendo seu foco no "hoje" e na "diversão". A justificativa da rebeldia se dá inicialmente pelo fato de que se trata de uma mulher injustiçada. Ela procura, no entanto, mais do que a tolerância do seu leitor. Ela deseja que eles reivindiquem para si o que ela reivindica para si própria, sendo essa a única maneira de enfrentar as injustiças. A crítica Nina Miller falou da poesia de Parker:

Parker turns outward to her audience, constituting herself in relation to a Other with whom she may be a fellow subject of a common culture. While this dinamic have a distincty infantilizing potential, it holds out the hope of a new ground for female identity - and a place in the interesting world. $(1999$, p. 132)

Enough Rope, sua coleção de poemas no qual "Now at Liberty" está inserido, foi publicada em dezembro de 1927 e se tornou instantaneamente um bestseller. Sua recepção por parte do público e da crítica, assim como seu humor malicioso e inteligente, impulsionaram a escritora a se tornar uma celebridade literária. Seu humor é uma crônica de seu tempo, oscilante entre a euforia e a desilusão. Edmund Wilson saudou "a extraordinária vivacidade e a franqueza que escapam a toda convenção literária". John

\footnotetext{
15“Parker se mostra para seu público, compondo a si mesma em relação ao Outro, com o qual ela se coloca como um tema conhecido de uma cultura comum. Enquanto essa dinâmica possui um potencial infantilizador aparente, ela sustenta a esperança de um novo degrau a ser galgado para a identidade feminina - e um lugar no mundo interessante" (Tradução nossa).
} 
Farrar, do Bookman proferiu sobre Parker: "um gigante das letras americanas, que escreve poesia como um anjo e críticas como um demônio."

Em seu poema "Men", dessa mesma coletânea, Dorothy Parker trata da maneira como as mulheres são vistas e da maneira como supostamente deveriam se comportar:

They hail you as their morning star

Because you are the way you are

If you return the sentiment,

They will try to make you different;

And once they have you, safe and sound,

They want to change you all around.

Your moods and ways they put a curse on;

They'd make of you another person.

They cannot let you go your gait;

They influence and educate.

They'd alter all that they admired.

They make me sick, they make me tired

Diferentemente do poema "Now at Liberty", apresentado anteriormente, não são duas vozes que se evidenciam, mas dois pontos de vista. Podemos perceber que Parker se coloca, como narradora e autora, fora da situação. A autora emite uma opinião na frase final, denotando sua impaciência e fadiga de lidar com essas questões. Por ser uma mulher à frente de seu tempo, ela representa um pequeno e seleto grupo de mulheres que se tornaram independentes e bem-sucedidas por meio de seu próprio trabalho, o que, sem dúvida, é uma difícil realização durante este período de mudança dos ideais vitorianos, no qual as mulheres ainda estavam começando a perceber que podiam ter identidades individuais.

Por ser uma mulher inserida no Round Table e nessa cultura da publicidade, Parker criou um vínculo íntimo com seu público, se apresentando como o tema ao invés de se colocar como manipuladora da cultura moderna.

Para Nina Miller (1999), o amor moderno e a sofisticação do Round Table foram as chaves para seu sucesso. Enquanto o "amor livre" e o casamento com direitos iguais se referiam a uma visão utópica da sociedade naquele momento, o amor moderno surgiu na idéia de que a relação entre os gêneros possuía falhas profundas e permanentes. Dessa forma, a estrutura central da narrativa moderna cujo tema é o amor se baseia na guerra dos sexos. 
Em seu conto “A Telephone Call” de 1928 e "The Waltz" de 1933, que serão analisados a seguir, as personagens não vão de encontro a nenhuma regra, elas estão totalmente inseridas nos ideais estabelecidos e sofrem as conseqüências por não conseguirem se livrar da dependência masculina. O humor é usado para mascarar a humilhação e a confusão sofridas pelas personagens por serem mulheres. Trata-se de histórias de dúvida, desconfiança e deslealdade, contada de uma perspectiva feminina. Em “A Telephone Call”, por não ser retratada como uma igual ao seu amado, e como a voz masculina não é ouvida, a ênfase da história gira em torno das conseqüências da rejeição masculina. Em “The Waltz”, as duas vozes da personagem são ainda mais evidenciadas, pois mesmo rejeitando seu parceiro e a situação em que se encontra, ela se submete a uma dança que se mostra eterna.

\section{A Espera Infinita}

“A Telephone Call” conta a história de uma mulher sem nome, que espera ansiosamente o telefonema do homem amado. Trata-se de uma jovem insegura, que submete sua aprovação pessoal e social à aprovação masculina.

Um dos contos mais famosos de Parker, a história fala de uma situação aparentemente trivial e totalmente identificável para as mulheres: a espera de um telefonema. Para aumentar ainda mais essa identificação, Dorothy Parker escolhe o uso do solilóquio como gênero dramatico. O solilóquio, que do latim Soliloquium significa falar sozinho, consiste na oralização do que se passa na consciência da protagonista, suas idéias e emoções são estruturadas de maneira coerente e lógica, ainda que partindo de um pensamento psicológico e não-racional, propiciando ao leitor saber o que se passa na cabeça da personagem mesmo na ausência de um interlocutor. Com essas características, a história atinge uma validade universal, o leitor contempla ao mesmo tempo em que vive junto com a personagem a possibilidade apresentada.

Em “A Telephone Call”, o cenário é estático. A história se passa na casa da protagonista, e possui pouca ou nenhuma ação. Ao contrário do drama, no qual a ação é essencial, na comédia, ela se torna acessória, uma vez que a atenção está voltada para a situação e a personagem. Esse critério de economia, de estrutura funcional, também coloca o leitor dentro da problemática, levando-o a ler o conto como se estivesse inserido nele. A 
história começa com a seguinte frase "Please, God, let him telephone me now." (p. 81) (“Oh, Deus, faça com que ele telefone agora.)” (p. 53).

Como vimos anteriormente, muitas comparações foram feitas entre Dorothy Parker e Ernest Hemingway e, em "Interchapter VII", do livro In Our Time podemos claramente perceber a semelhança com o conto de Parker: While the bombardment was knocking the trench to pieces at Fossalta, he
lay very flat and sweated and prayed oh jesus christ get me out of here.
Dear jesus please get me out. Christ please please please christ. If you'll
only keep me from getting killed I'll do anything you say. I believe in
you and I'll tell every one in the world that you are the only one that
matters. Please please dear jesus. The shelling moved further up the line.
We went to work on the trench and in the morning the sun came up and
the day was hot and muggy and cheerful and quiet. The next night back at
Mestre he did not tell the girl he went upstairs with at the Villa Rossa
about Jesus. And he never told anybody. (p. 87)

A própria comparação já é cômica, pois, enquanto o soldado pede a Jesus para sobreviver, a personagem de Parker pede a Deus, supostamente ainda mais poderoso, para receber um telefonema de seu amado. As situações se equivalem para ambos os sofredores. No texto de Hemingway, a repetição é o ponto em comum com o conto de Parker que se faz mais evidente, pois assim como o soldado implora por sua vida, no conto de Parker, como veremos a seguir, mesmo após se revoltar várias vezes contra as forças superiores, a personagem sempre volta a suplicar por ajuda.

Em “A Telephone Call”, logo na primeira sentença, os papéis são definidos: Ao apelar para Deus e repetir "Please, God. Please, please, please.” a personagem estabelece um comportamento infantil uma vez que afasta de si a possibilidade de ação, e perde o controle sobre seu objetivo, reforçando a dominação masculina. O soldado de Hemingway não possui controle sobre os ataques inimigos, por isso reza. A personagem de Parker não possui controle sobre seu amado, mas se mostra de maneira totalmente passiva tanto em relação ao Deus para quem ora, quanto para o homem que deseja. Essa dominação masculina é evidenciada quando ela diz: "I know you shouldn't keep telephoning them. I know they don't like that. When you do that, they know you are thinking about them and wanting them and that makes them hate you." (p. 81) ("Sei que não se deve ficar telefonando para eles no trabalho - eles não gostam muito. Quando você faz isso, eles sabem que você está pensando neles, que está precisando deles, e eles odeiam isso.”) (p. 54). 
A personagem precisa se policiar o tempo todo para não sucumbir à tentação de telefonar para ele. Ela pede repetidamente à Deus: “Oh, God, please don’t let me telephone him.” (p. 84) (“Por favor, meu Deus, não deixe que eu ligue para ele.”) (p. 59) pois as regras sociais não permitem que ela ligue para ele e, principalmente, que mostre seus sentimentos. Isso pode ser percebido pelo uso do plural: "I know you shouldn't keep telephoning them”. (“Sei que não se deve telefonar para eles.”) Não se trata, então, de uma situação imposta pelo seu homem em particular, mas de uma regra criada pela sociedade. Telefonar para ele - o que descobrimos depois ela já ter feito quando diz: "He couldn't have minded that. He couldn't have thought I was bothering him. "No, of course you're not", he said" (p. 81) ("Ele não poderia ter se aborrecido com isso. Não poderia pensar que eu estava o importunando. "Não, claro que não", ele disse") (p. 54) - significaria violar um tabu social.

Por serem encubados, seus sentimentos explodem em raiva, desespero e súplica. Seu único interlocutor, para quem pode se revelar por inteiro, é, portanto, Deus. Este, definido pela etiologia patriarcal como um Deus - pai - masculino, criador de todas as coisas, reforça a aceitação da personagem a uma superioridade masculina e a ansiedade em relação a sua incapacidade de agir, enquanto mulher.

Como Deus não atende seu pedido, ela passa então a praguejar contra ele:

Oh, don't laugh God. You see. You don't know how it feels. You're so safe, there on your throne... This is suffering, God, this is bad, bad suffering... Oh God, in the name of Thine only beloved Son, Jesus Christ, let him telephone me now. (p. 82)

Não ria, meu Deus. O senhor não sabe o que é isto. O senhor está seguro aí nas nuvens... Pois isto é o sofrimento, meu Deus, muito sorimento... Oh, meu Deus, em nome de Jesus Cristo, nosso senhor, faça com que ele me telefone agora. (p. 54)

A comicidade se manifesta até então, além da situação humilhante e estática na qual a personagem se encontra, no fato dela personificar a figura mítica que atribui tanto poder. Ao criar a imagem de um homem sentado em um trono, desprezando o sofrimento de uma mortal, temos o que Henri Bergson chama de degradação, uma situação na qual o solene é transposto para o trivial. (2004, p. 93)

No conto de Hemingway descrito anteriormente também podemos perceber que, apesar da situação não ser trivial, pois se trata de uma guerra, o poder e a esperança são colocados numa força superior, como se somente a intervenção divina pudesse salvar o 
soldado, e isso se daria mediante uma contrapartida por parte dele, ou seja, seguir os preceitos da religião e se dedicar a divulgar o nome de Jesus como único salvador. Ele implora: "Dear jesus please get me out. Christ please please please christ. If you'll only keep me from getting killed I'll do anything you say."

No conto de Parker, porém, além de implorar, a personagem se enfurece, o que pode ser percebido através de suas duas vozes, a pública, feminina e agradável, e a sua voz de descontentamento, introspectiva e subversiva. Essa contradição gera humor, pois apesar dela prometer a Deus "I'll be good, God. I will try to be better, I will, if You will let me see him again" (p. 120) ("Prometo ser boazinha, meu Deus. Tentarei ser melhor, se Deus me deixar vê-lo de novo.”) (p. 54), conforme o tempo passa, a personalidade da personagem se torna mais violenta e sua linguagem se intensifica, passando a conter gírias e coloquialismos, assim como mais violência contra o homem amado, ao desejar poder fazê-lo chorar ou "hurt him like hell" (p. 121). Nem o aparelho de telefone escapa à sua fúria:

\begin{abstract}
Why can't that telephone ring? Why can't it? Couldn't you ring? Ah, please, couldn't you? You dammed ugly, shiny thing. It would hurt you to ring, woudn't it? Oh, that would hurt you. Damn you, I'll pull your filthy roots out of the wall. I'll smash your smug black face in little bits. Damn you to hell. (p. 82)

Por que o raio deste telefone não toca? Por que, por quê? Por que você não toca, seu chato? Bobo, feio, lindo. Ia te machucar se tocasse? Claro, ia te machucar. Pois vou arrancar os seus fios da parede e esmagar essa merda de aparelho preto em pedacinhos, seu merda. (p. 55)
\end{abstract}

Ela amaldiçoa o objeto responsável por sua infelicidade ao mesmo tempo em que o ameaça. Da mesma maneira que faz com a figura de Deus, o telefone é personificado e tratado como cúmplice, senão culpado por sua desgraça. A trivialidade da situação se choca com a intensidade da personagem, produzindo humor.

Em seu pensamento, qualquer coisa seria melhor do que não receber o telefonema, até mesmo aceitar a morte daquele por quem tanto sofre. Ela deseja:

I wish he were dead. That's a terrible wish. That's a lovely wish. If he were dead he would be mine. If he were dead, I would never think of now and the last few weeks. I would remember only the lovely times. It would be all beautiful. I wish he were dead. I wish he were dead, dead, dead.(p. 83)

Queria que ele estivesse morto. Esse desejo é terrível. Uma gostosura de desejo. Se estivesse morto, ele seria meu. Se estivesse morto, eu não estaria pensando no agora e nas últimas semanas. Iria pensar apenas nos 
momentos felizes. Seria tão lindo. Gostaria que ele estivesse morto. Morto, morto, morto. (p. 57)

Ao mesmo tempo em que implora e se enfurece, podemos observar que a personagem pune a si mesma. A razão disso é por ter violado não só tabus sociais, como sexuais também, pois existe uma regra a qual ela sabe ter desobedecido, descrita ambiguamente como "that". Ela fala com Deus: "Are you angry with me because I did that?" (p. 82) (“O senhor está brabo comigo só por que eu fiz aquilo?”) (p. 56) Este "that” poderia se referir ao telefonema, mas em seguida ela diz: "We didn't hurt one single soul; you know that. You know it wasn't bad, don’t You, God?" (p. 83) ("Não magoamos ninguém, nem eu, nem ele. O senhor sabe disto, não é, meu Deus? E sabe também que foi gostoso.”) (p. 56)

Nessa frase, a personagem usa o pronome "we". Dessa forma, não se trata do telefonema que ela fez de manhã para ele, mas de terem tido relações sexuais, dada a posição defensiva e furiosa quanto à ausência do telefonema. A crítica Sondra Melzer analisa essa questão de total desigualdade, uma vez que o amor físico para a mulher sempre implica num senso de perda, como na perda da virgindade, da pureza, da reputação, enquanto que para o homem, a experiência sexual é mais frequentemente definida como um ganho, um triunfo, uma conquista. (1997, p. 60)

A personagem sabe que tem se "comportado mal", então, nos únicos moldes que uma mulher pode se "comportar mal" de acordo com as expectativas sociais tradicionais. Apesar do telefonema só estar atrasado duas horas e dez minutos (são sete horas e dez minutos quando a história se inicia e ele prometera ligar às cinco horas), sua reação é extremada pois além de simbolizar que ele também a quer, o telefonema possibilitaria, para ela, uma possível redenção, ou seja, significaria que o que ela fez não foi assim tão mal: "If he doesn't phone me, I'1l know God is angry with me”.(p. 83) (“Se ele não telefonar, então saberei que o Senhor está zangado comigo.”) (p. 56) Mas ela, porém, já sentencia a si mesma e suas ações: "It was bad. I knew it was bad. All right, God, send me to hell. You think You're frightening me with Your Hell, don't You? You think Your Hell is worse than mine?" (p. 83) ("Eu sabia que não ia dar certo. Está bem, Deus, então me mande para o inferno. Pensa que me assusta com o Seu inferno, não é? Pois o Seu inferno não chega aos pés do meu.”) (p. 56) 
Ao, comicamente, se colocar no mesmo patamar que o Deus para quem ela tanto implora, seu respeito e louvor são transformados em raiva e sentimento de rejeição. A extensão dessa rejeição sofrida por ela é simbolizada na contagem até quinhentos, de cinco em cinco, feita no começo e no fim da história, enquanto espera o telefonema. Assim, qualquer tipo de ação é excluída, e é mantida metaforicamente a passividade da personagem.

Mais adiante, vemos que esse exagero na busca pela atenção masculina e pela aprovação do ser amado representa a confirmação da sua própria identidade. Trata-se da máxima que diz que os homens competem pela aprovação do mundo, enquanto que as mulheres competem pela aprovação dos homens. Ela existiria então, somente como produto das necessidades dele. A personagem revela:

They don't like you to tell them they have made you cry. They don't like you to tell them you're unhappy because of them. If you do, they think you're possessive and exacting. And then they hate you. They hate you whenever you say anything you really think. You always have to keep playing little games. (p. 83)

Eles não gostam que você conte que a fizeram chorar. Não gostam que você lhes diga que está infeliz por causa deles. Se você faz isso, eles a consideram possessiva e exigente. E aí te odeiam. Te odeiam por você dizer o que sente. É preciso estar sempre fingindo. (p. 57)

Apesar de saber das regras e falar com propriedade, ela desejaria que tudo fosse diferente. Ela lamenta com clareza e sinceridade: “Oh, I thought we didn't have to (play games), I thought this was so big that I could say whatever I meant. I guess you can't, ever.” (p. 83) (“Oh, pensei que, desta vez, não iria precisar; achei que era um amor tão grande que poderia dizer o que quisesse. Mas já vi que não, nunca.”) (p. 57)

Trata-se da eterna batalha entre o que esperam que ela sinta e a maneira como deve se comportar, e do quê ela sente realmente e de como gostaria de se comportar, ou se comporta.

De acordo com Bergson, a comicidade isola o sentimento que é atribuido ao personagem e faz dele um estado parasita dotado de existência independente. (2004, p. 103) O exagero, então, é um dos instrumentos usados pela autora para representar o ser humano na sua perspectiva cômica. Para Propp, as três formas fundamentais de exagero são a caricatura (exagero de um pormenor), a hipérbole (exagero do todo) e o grotesco (grau extremo, que gera o monstruoso). Na prosa realista de Parker o modo escolhido é a 
caricatura, acentuando características comuns à grande maioria das mulheres da época. Por caricatura, entendemos, então, um tipo de retrato que torna a pessoa ridícula por exagerar ou distorcer aspectos proeminentes de seu caráter, sem com isso perder a similitude. (ABRAMS, 1961, p. 10)

Hobbes (2002), que pensava ser o riso um tipo de glória repentina, proferiu em "Leviatã", que o riso se origina dessa noção súbita da nossa superioridade por comparação com a deformidade dos outros, neste caso a personagem do conto, ou com a nossa num tempo anterior, pois os homens riem das suas próprias loucuras passadas quando elas subitamente lhe ocorrem à memória, o que nos permite concluir que o distanciamento promove a comédia, enquanto o sentimento e a proximidade da situação não permitem sua análise crítica.

Então, conformada e acomodada nessa situação passiva, a personagem, totalmente imersa em seu martírio, promete que se ele ligar, ela vai se comportar bem, não vai contar que esteve triste e vai ser tão legal com ele que não haverá jeito dele não gostar dela. Os jogos de fingimento e de superficialidade das relações, que ela gostaria que ele não jogasse, são agora por ela propostos. Não que isso não demande bastante esforço de sua parte, pois ela reconhece: "Oh, it's so easy to be sweet to people before you love them." (p. 82) (“Oh, é tão fácil ser doce com uma pessoa antes de você começar a amá-la.”) (p. 55).

O humor provém dessa alternância entre consciência e desespero, docilidade e violência, culpa e paixão, clareza de raciocínio e loucura e são exatamente essas ambiguidades e incongruências que criam identificação com o leitor. A personagem pede a Deus que lhe permita ter ainda um pouco de orgulho e em seguida profere que talvez o verdadeiro orgulho é não ter orgulho. Ao se desmentir o tempo todo, ela fica cada vez mais confusa, mais nervosa, mais ansiosa e mais engraçada. Esse pêndulo emocional, assim como a tensão proposta pela situação constituem a estrutura dessa história cômica.

A personagem tenta se distrair lendo um livro e imediatamente chama de mentirosos aqueles que escrevem livros sobre o amor romântico e verdadeiro: "Don't they know it's a lie ... God damned lie ... What do they have to tell about that for, when they know how it hurts. Damn them, damn them, damn them" (p. 85). ("Não sabem que é mentira? Uma merda duma mentira? Por que escrevem sobre isso, quando sabem que machuca? Merda, merda, merda.”) (p. 59) Nada do quê ela faça a tirará do foco, da idéia fixa e desesperadora do telefonema. Por baixo de uma superfície humorística o conto denuncia o desespero real de uma mulher cuja relação com seu homem e consigo mesma é 
definida em termos de rejeição, desapontamento, culpa e humilhação. Por trás da paródia de um comportamento social, usado como temática, é revelado um sofrimento lento e solitário por parte de uma mulher "pecadora". Ela está presa numa situação que permitiu que ocorresse, mas que não possui assertividade nem os recursos necessários para se libertar.

Pirandello diz que na concepção de uma obra humorística a reflexão não se esconde, como no momento da concepção de uma obra de arte qualquer, mas coloca-se diante do sentimento e o decompõe. Dessa decomposição emana o sentimento do contrário. Ele aponta que qualquer efeito cômico percebe o contrário, mas só a reflexão é capaz de transformar essa percepção em sentimento. (1996, p. 12) Essa ocorrência pode ser observada na personagem de "A Telephone Call". Ao olharmos para ela, nas suas repetições e em seu comportamento infantil, rimos dela, mas quando percebemos que ela está inserida numa sociedade que condena atos como o cometido por ela (ter tido relações sexuais com ele ou mesmo telefonar para ele) e que ela possui total dependência da aprovação masculina, o leitor é levado para além da superfície, de modo que a reflexão leva ao sentimento. É como se algo interferisse no riso e tornasse a personagem digna de pena e comiseração.

A autora satiriza essas mulheres enfadonhas e acomodadas em suas vidas vazias e, ao apresentar os resultados da subordinação e do condicionamento cultural feminino, Parker, enquanto mulher e humorista, implicitamente chama atenção para a origem da insegurança feminina, de sua dependência em relação ao sexo masculino e de sua inércia. Como disse Antônio Cândido: "Nada mais importante para chamar a atenção sobre uma verdade do que exagerá-la" (1965, p. 3)

Esse exagero, que também é uma característica do texto de Hemingway visto nesse capítulo, não se mostra, entretanto, ser a única semelhança entre as duas obras. Ambas as personagens, o soldado e a mulher de "A Telephone Call”, fazem promessas a Deus caso seus desejos sejam realizados. No conto do autor, a personagem profere: "I believe in you and I'll tell every one in the world that you are the only one that matters. Please please dear jesus." Em seguida, o leitor é informado de que ele conseguiu sobreviver àquela noite. Suas preces foram atendidas. Apesar disso o autor informa: "The next night back at Mestre he did not tell the girl he went upstairs with at the Villa Rossa about Jesus. And he never told anybody." A personagem não cumpre o que prometera e esquece, não só de que seu pedido foi atendido, mas de que por um momento suplicou a uma força superior. Dessa maneira, portanto, é feita uma sátira ao mundo masculino, que não admite suas fraquezas nem divide suas glórias. 
Já no conto de Parker, as preces da personagem não são atendidas e a maneira de representar sua cegueira duradoura é chamando a atenção do leitor para a verdade por trás de seu triste destino, terminando a história na contagem até quinhentos de cinco em cinco, entremeada pela súplica a Deus pela atenção do homem amado. Seu problema permanece sem solução. O final circular e aberto dá a impressão que essa mulher está para sempre condenada à espera, uma vez que nenhuma possibilidade de ação verdadeira é apontada. A personagem não rejeita as regras sociais, mas a autora, via sua sátira, sim. Como bem aponta Charles Knight, o propósito de sua sátira é, então, a percepção por parte do leitor, mais do que a mudança comportamental em si, apesar de a mudança de comportamento provavelmente vir a derivar dessa mudança de percepção. (2004, p. 5) A provocação é então seu propósito, tanto da sátira como da autora nesse conto, que mostra uma caricatura cruel do modo como as mulheres respondem emocionalmente e linguisticamente a uma hierarquia masculina na qual são constantemente desvalorizadas.

\section{A Dança Eterna}

Muitos amigos de Dorothy Parker ficaram surpresos com a conversão política da autora na década de trinta. Já em 1927 a escritora marchou no protesto contra a execução de Nicola Sacco (1891-1927) e Bartolomeo Vanzetti (1888-1927), imigrantes italianos condenados por assassinato em um julgamento que muitos consideraram injusto. Deixando para trás os anos do Algonquin Round Table, Parker abandonou Nova York para logo se tornar uma das mais bem pagas roteiristas de Hollywood. Lá, ela fundou o primeiro sindicato de roteiristas de cinema. Parker também promoveu um comitê para defender os garotos de Scottsboro, oito meninos negros acusados de estuprar duas mulheres brancas no Alabama.

A escritora organizou jantares e campanhas anti-fascistas e se uniu a mais de trinta organizações políticas. E ela não estava sozinha, muitos escritores como John dos Passos participaram das atividades ao seu lado. A América nos anos trinta ostentava uma esquerda livre e ativa. Parker ajudou a fundar a Liga Anti-Nazista em 1936 e viajou para a Espanha, relatando a guerra civil que lá acontecia, na publicação de esquerda New Masses. Como muitos americanos nessa época, Dorothy Parker estava assustada com a depressão e a crescente pobreza que se instalava. 
Os anos de envolvimento político de Dorothy Parker coincidiram com o apogeu de seus contos e coleções de seus trabalhos surgiram na segunda metade dos anos 1930. Parker escreve histórias dedicadas a temas como racismo e intolerância, como, por exemplo, seu conto "Arrangement in Black and White", no qual retrata o preconceito de uma mulher da sociedade em uma festa em homenagem a um famoso músico negro. A personagem pede ao anfitrião:

I want to meet Walter Williams. Honestly, I'm just simply crazy about that man. Oh, when he sings! When he sings those spirituals! Well, I said to Burton, 'It's a good thing for you Walter Williams is colored,' I said, 'or you'd have lots of reasons to be jealous.' I'd really love to meet him. I'd like to tell him I've heard him sing. Will you be an angel and introduce me to him? (p. 77)

Quero conhecer Walter Williams. Sinceramente, sou louca por esse homem... Outro dia eu estava dizendo para Burton, "Sorte sua Walter Williams ser preto, ou você teria um monte de razões para ficar com ciúmes". Eu adoraria ser apresentada a ele, para lhe dizer que já o vi cantar. Você vai ser um anjo e me apresentar? (p. 27)

A personagem nutre uma grande admiração pelo cantor, e se diz livre de qualquer preconceito, colocando essas características em seu marido Burton, que nem fora à festa. A personagem profere, ao longo da história, todo tipo de absurdos. A sua fala final ilustra a situação:

"I liked him," she said. "I haven't any feeling at all because he's a colored man. I felt just as natural as I would with anybody. Talked to him just as naturally, and everythung. But honestly, i could hardly keep a straight face. I kept thinking of Burton. Oh, wait till I tell Burton I called him 'Mister'!” (p. 85)

- Gostei dele - disse ela. - Não tenho nada contra ele pelo fato de ser negro. Me senti tão à vontade com se estivesse conversando com uma pessoa normal. Mas, sinceramente, às vezes eu tinha que me forçar um pouco. Não parava de pensar em Burton. Oh, mal posso esperar para contar a Burton que chamei o crioulo de senhor! (p. 32)

Por meio da ironia, que é utilizada como ferramenta para promover uma tomada de consciência, podemos perceber o preconceito intrinsecamente relacionado. Trata-se do desacordo entre a vida e o ideal humano, entre as aspirações da personagem e suas fraquezas e misérias.

Na maioria de suas histórias, porém, Dorothy Parker procura revelar como é fazer parte da primeira geração de mulheres que sustentam a si próprias, e tentam viver e amar 
do mesmo modo que os homens o fazem. Isso não implica todavia retratar suas personagens como tais. A autora toma o caminho inverso e apresenta personagens tipo, dependentes e desprovidas de segurança. De acordo com Henri Bergson, a personagem cômica é um tipo, uma vez que é cômico vir inserir-se numa moldura preparada, ou seja, ter um caráter solidificado. $(2004$, p. 111)

No conto "Arrangement in Black and White", Parker, ao invés de elaborar personagens que lutam contra o preconceito e levantam bandeiras, constrói uma personagem sem qualquer consciência, e que, pelo contrário, está certa de não possuir qualquer tipo de receio. Da mesma forma, em seus contos estudados neste trabalho, a autora dialoga com as duas identidades da mulher; uma construída, imposta pela sociedade patriarcal e vivenciada por suas personagens e a outra, que a autora pretende libertar por meio da catarse provocada em quem a lê.

Publicada pela primeira vez em 1933 no The New Yorker, "The Waltz" conta a história de uma mulher solteira, inteligente, já mais velha, e de seu parceiro indesejável.

Ao contrário do que acontece em "A Telephone Call", entretanto, a rejeição é manifestada na personagem masculina. E o que vemos é a maneira como a personagem feminina lida com essa outra forma de prisão.

Nesse conto, Parker escolhe o monólogo como gênero dramático a ser criado. Inicialmente, o monólogo, do grego, e o solilóquio, do latim, eram sinônimos, porém hoje podemos diferenciá-los definindo o monólogo como um discurso feito por alguém na companhia de outras pessoas e solilóquio como um discurso feito por alguém que está sozinho. De qualquer forma, em ambos a personagem expressa com meios próprios o que lhe vai à consciência, não havendo a interferência de um narrador. São feitos sempre na primeira pessoa e dirigem-se ao leitor como se a personagem dialogasse com um interlocutor calado.

Por estar casada com um ator, frequentar teatros regularmente, fazer crítica de peças, e estar em contato com performers, produtores e dramaturgos, Dorothy Parker é bastante influenciada pela escrita para os palcos. E assim como no teatro, nesse conto a personagem constitui praticamente a totalidade da obra, nada existe a não ser através dela. $^{16}$

\footnotetext{
${ }^{16}$ Décio de Almeida Prado diz ser esta a maior diferença do teatro para o romance, no capítulo "A personagem do teatro" no livro A Personagem de Ficção.
} 
Para a crítica Sondra Melzer, nenhum conto é tão dramático quanto "The Waltz". Ela ponderou: “A justaposição das vozes pública e privada do narrador é o maior artifício estrutural assim como a base de seu humor, além de, o que é mais importante, nos guiar para o inferno pessoal do narrador" ${ }^{\prime 17}$ (tradução nossa)

O cenário é único, um salão de baile sem especificação de estilo ou do ambiente que o cerca. O conflito central se passa no interior do próprio narrador, uma mulher que não é nomeada, dividida entre sua responsabilidade social para com seu parceiro de dança e sua aversão pessoal por ele, uma vez que aceita a dança ao invés de negar o convite e permanecer sozinha num canto do salão.

É estabelecida desde o começo uma convenção gráfica no texto: em itálico está o que a personagem diz e em letras normais o que ela pensa. Num total de cinco páginas, sete pequenas falas italizadas se alternam com seis longos discursos não itálicos de monólogo interior. Ou seja, é dado muito mais enfoque ao que a personagem pensa do que ao que ela diz.

Seguindo a tipologia estabelecida por Norman Friedman (apud. LEITE, 1985, p. 25), o conto "The Waltz" é narrado em primeira pessoa, possuindo assim um narradorprotagonista, que não tem acesso ao estado mental das demais personagens. A personagem fala consigo mesma, ao mesmo tempo em que seus pensamentos são interrompidos por diálogos que esta trava com a personagem masculina.

A autora, porém, escolhe não mostrar a voz masculina, sendo esta decifrada por meio das respostas da personagem feminina. Esta abre a história aceitando um convite para uma dança: “Why, thank you so much. I'd adore to.” (p. 209) ("Oh, encantada. Adoraria.”) (p. 19)

Trata-se da resposta a uma pergunta feita antes do começo da história e é parte da linguagem externa do narrador dirigida ao seu parceiro de dança. Em seguida, o narrador desmente suas próprias palavras no que percebemos serem seus pensamentos: "I don't want to dance with him. I don't want to dance with anybody. And even if I did, it wouldn't be him.” (p. 209) ("Não quero dançar com ele. Não quero dançar com ninguém. E, mesmo que quisesse, não seria com ele.”) (p. 19)

\footnotetext{
17، The juxtaposition of the private and public voice of the narrator is the major structural device of the story as well as the source of its humor, but more importantly keys us into the personal hell of the speaker." MELZER, Sondra. op. cit., p. 99.
} 
Dorothy Parker constrói uma história na qual o humor torna o leitor cúmplice dos fatos. É com ele que a personagem fala de forma cômica. E é cômica devido à crítica que este a impõe. Dessa forma, é rompido o ciclo de intersubjetividade da personagem, e sua situação é compartilhada pelos leitores, a quem as ironias são destinadas. A ironia, para Lélia Parreira Duarte, autora do livro Ironia e Humor na Literatura, é a afirmação de um indivíduo que reconhece a natureza intersubjetiva de sua individualidade. Esta serve à literatura quando busca um leitor que não seja passivo, e sim atento e participante, capaz de perceber que a linguagem não tem significados fixos e que o texto pode apresentar armadilhas e jogos de enganos dos quais ele deverá, eventualmente, participar. (2006, p. 19)

Há no conto de Dorothy Parker, claramente, a presença das duas identidades da protagonista. Avançando em termos técnicos, o conto segue os passos ensaiados no conto "A Telephone Call". Assim como neste conto, "The Waltz" é escrito em primeira pessoa. $\mathrm{O}$ "Eu" narrador, porém, é tanto literal quanto metaforicamente um ser dividido. Este, ativamente envolvido nos eventos, conta a história ao mesmo tempo em que a experiencia, gerando intimidade e identificação com o leitor. Essa relação é estabelecida logo no início do conto quando a personagem pensa: "Just think, not a quarter of an hour ago, here I was sitting, feeling so sorry for the poor girl he was dancing with. And now I'm going to be the poor girl. Well, well. Isn’t it a small world?" (p. 209) (“Imaginem, a menos de quinze minutos, eu estava com pena da pobre coitada que dançava com ele. E agora $e u$ é que vou ser a pobre coitada. Não é mesmo um mundo muito pequeno?”) (p. 19)

No início e no final da frase a personagem se dirige a um interlocutor fora da situação. Ela procura essa cumplicidade. E continua em seguida: "And a peach of a world too. A true little corker. Its events are so fascinatingly unpredictable, are not they?" ("E é uma delícia de mundo, também. Tudo que acontece nele é tão fascinante e imprevisível, não?”)

Assim tem início a evolução dos pensamentos da personagem enquanto a dança se torna uma provação dolorosa tanto física quanto emocionalmente. Alternando entre diálogo externo e monólogo interno, a história revela que não só o ressentimento da personagem por seu parceiro de dança cresce, como também seu desprezo pelas convenções sociais que se sente forçada a se submeter. Publicamente ela afirma que "adora" a valsa, e privadamente compara a dança com a noite principal do diabo, o sabbath das bruxas. Ela pensa: "But what could I do? Every one else at the table had got up to 
dance, except him and me. There I was, trapped. Trapped like a trap in a trap." (p. 209) ("Mas, o que eu podia fazer? Todo mundo já estava dançando, exceto eu e ele. Eu estava numa arapuca. Como uma arapuda dentro de outra arapuca.”) (p. 20) Para ela, não haveria como ter escapado.

Ela diz a ele: "I'm simply thrilled. I'd love to waltz with you." (p. 210) ("Estou arrepiada. Não, claro, adoraria dançar com você") (p. 20), e em seguida pensa "I'd love to waltz with you. I'd love to have my tonsils out. I'd love to be in a midnight fire at the sea. Well, it's too late now. We're getting under way." (p. 210) (“Adoraria dançar com você. Adoraria também extrair as amígdalas. Adoraria estar em um barco em chamas. Mas agora é tarde. Já estamos a caminho da pista.”) (p. 20)

O rapaz parece não dançar bem e chuta sistematicamente a canela da personagem. Ela solta um sigelo gemido: “Ow!' para em seguida pensar: "For God’s sake, don’t kick, you idiot; this is only second down. Oh, my shin. My poor, poor shin, that I've had since I was a little girl.” (p. 211) (“Ai! Puxa, pare de me chutar, seu idiota! Já é a segunda vez que você me acerta a canela. É minha canela de estimação. Tenho-a desde que era garotinha.”) (p. 21)

A crítica Suzanne Bunkers (1978) observou a ironia presente naquilo que a personagem diz em contrapartida ao desgosto que sente com o papel que é esperado que desempenhe. Para Bunkers, seu humor e seus pensamentos sarcásticos revelam sua verdadeira fúria interna. Essa mesma ironia pode ser observada no poema Love Song, escrito por Parker em 1926:

My own dear love, he is strong and bold, And he cares not what comes after.

His words ring sweet as a chime of gold, And his eyes are lit with laughter. He is jubilant as a flag unfurledOh, a girl, she'd not forget him. My own dear love, he is all my worldAnd I wish I'd never met him.

My love, he's mad, and my love, he's fleet, And a wild young wood-thing bore him!

The ways are fair to his roaming feet, And the skies are sunlit for him. As sharply sweet to my heart he seems As the fragrance of acacia. My own dear love, he is all my dreamsAnd I wish he were in Asia. 
My love runs by like a day in June,

And he makes no friends of sorrows.

He'll tread his galloping rigadoon

In the pathway of the morrows.

He'll live his days where the sunbeams start,

Nor could storm or wind uproot him.

My own dear love, he is all my heart-

And I wish somebody'd shoot him."

A disparidade de sentimentos chama a atenção, e gera a comicidade. Na última frase de cada estrofe percebemos que a situação construída é subvertida. Na primeira estrofe temos: "And I wish I'd never met him" que rima com "Oh, a girl, she'd not forget him.”, porém muda completamente o sentido que se vinha estabelecendo até então. $\mathrm{Na}$ estrofe seguinte a autora escreve: "And I wish he were in Asia., que rima com "As the fragrance of acacia." e subverte a frase anterior que diz "My own dear love, he is all my dreams." Por fim, e mais sarcástica do que as frases anteriores, Parker fecha o poema com: “And I wish somebody'd shoot him".

De acordo com Henri Bergson, o efeito cômico é obtido transpondo para outro tom a expressão natural de uma idéia. $O$ riso também nasce quando nos apresentam uma coisa, antes respeitada, como medíocre e vil. (2004, p. 93) No caso do poema, e do conto The Waltz, esse tipo de comicidade inclui a degradação e o exagero.

No conto, a comicidade das palavras segue a comicidade da situação (a dança), que acaba por desaguar na comicidade de caráter, mostrando a inadaptação particular da personagem à sociedade. Para Bergson, esse é o motivo pelo qual a comédia está mais perto da vida real que o drama. Quanto mais grandeza tem um drama, mais profunda é a elaboração à qual o poeta precisa submeter a realidade, para depreender a sua tragicidade em estado puro. Ao contrário, é somente com o exagero que a comédia contrasta com a realidade, pois quanto mais se eleva, mais tende a confundir-se com a vida. (2004, p.102) Esse exagero pode ser percebido nos xingamentos que a personagem destina a seu parceiro: "Die he must, and die he shall, for what he did to me" (p. 210) ("Mas vai morrer pelo que fez comigo!") (p. 21), e também no modo com o qual fala de maneira doce e gentil quando se dirige a ele: Well, aren't you amazing! Oh, I think it's lovely” (p. 211) (“Incrível! É excitante!”) (p. 23).

Conforme a história segue, o diálogo externo da personagem continua a reiterar seu falso prazer quando valsa com seu companheiro de dança, enquanto seu monólogo interno 
ferve de ódio à gama das indignidades às quais ela está sujeita, incluindo a inabilidade dele para a dança, seu comportamento como homem, e sua acomodação como mulher.

Em dado momento, a personagem, mesmo partindo da ironia, parece estar rumo à conciliação com ele. Ela exclama:

...For a while I tought they'd have to carry him off the field. Ah, I couldn't bear to have anything happen to him. I love him. I love him better than anybody in the world. Look at the spirit he gets into a dreary, commonplace waltz; how effere the other dancers seem, beside him. He is youth and vigor and courage, he is strength and gaiety and - (p. 211)

... Por um momento pensei que iam expulsá-lo da pista. Não suportaria que algo lhe acontecesse. Eu o adoro. Adoro-o mais que qualquer outra coisa no mundo. Incrível a animação que ele tira de uma valsa chocha e vulgar; em comparação, os outros dançarinos parecem uns palermas. Ele representa a juventude, o vigor e a coragem, a força e a alegria e - (p. 22)

Nessa fala parece que, enfim, uma das vozes irá prevalecer, como se sua resistência interna tivesse se rendido. No mesmo instante, porém, o desajeitado dançarino pisa novamente em seu pé, o que a leva imediatamete de volta às reações internas inflamadas, impossibilitando sua redenção: “- Ow! Get off my instep you hulking peasant! What do you think I am, anyway - a gangplank? Ow!” (p. 211) (“Ai! Saia de cima do meu pé, seu caipira! Por que não pisa em sua avó?’”) (p. 22)

A maioria das técnicas de humor envolve uma agressão e hostilidade mascaradas, porém em "The Waltz" os insultos são explícitos e os sentimentos submersos são tornados óbvios. Quando o parceiro de dança se desculpa pela sua inabilidade, entretanto, a personagem dissimula, e inverte a situação: "No, of course it didn't hurt. Why, It didn't a bit. Honestly. And it was all my fault." (p. 211) ("Não, claro que não doeu. Ora, nem um pouco. Sinceramente. E foi minha culpa.”) (p. 22)

Podemos perceber, nesses comentários, interrupções bruscas das linhas de reflexão. Essa elasticidade da personagem denota sua incongruência, e gera a comicidade.

O riso provocado, porém, não é desenfreado nem expansivo. Ele brota da situação, do desencadear dos fatos, e também do que não está dito, como por exemplo todo o discurso masculino e seu comportamento.

Os elementos cômicos estão conciliados, nessas passagens, com elementos sérios. Uma vez que na superfície há a trivialidade da situação, que é claramente engraçada, uma outra leitura do texto sugere o verdadeiro terror escondido da existência da protagonista 
por se tratar de uma mulher de idade mais avançada, presa em uma armadilha com um homem que ela desdenha. Estruturalmente, essa dicotomia reflete o conflito da personagem entre o desejo de disfarçar e o desejo de revelar, e mostra também como em diferentes situações, diferentes identidades são reveladas, sendo a identidade não uma essência, mas uma construção contextual.

Enquanto o poeta épico ou dramático deseja tornar seu herói coerente em cada ato, o humorista faz exatamente o inverso, decompondo o caráter do personagem e se divertindo ao apresentar o herói em suas incongruências. A idéia por trás disso, porém, não é abstrata, mas um sentimento que se torna centro da vida interior e a agita suscitando imagens de contraste. (BERGER, 1993, p. 12)

Após algum tempo valsando, a personagem descreve o estado em que se encontra:

My hair is hanging along my cheeks, my skirt is swaddled about me, I can feel the cold damp of my brow. I must look like something out of "The Fall of the House of Usher." This sort of thing takes a fearful toll of a woman my age. (p. 211)

Estou completamente descabelada, minha saia está toda enroscada em meu corpo, posso sentir um suor frio na testa. Devo estar parecendo algum espectro saído de "A Queda da Casa de Usher". Essas coisas não devem fazer bem à saúde de uma mulher da minha idade (p. 23)

Ela compara sua aparência aos personagens do conto de Poe, que trata da ruína de uma família por meio do terror e do sobrenatural.

Para Pirandello, ao se apresentar uma reflexão cômica, o leitor somente rirá, contentando-se em esvaziar esta metáfora dele mesmo edificada pela ilusão espontânea. Já com o uso da sátira, o lado sério e doloroso é visto através do ridículo e desmonta essa construção com intuito não apenas de rir dela, mas de que no lugar de desdenhar-se dela, rindo, se compadeça. (1996, p. 156)

Por outro lado, se considerarmos seus escritos satíricos, como Dorothy Parker gostaria, seria necessário considerar a sátira como dotada de um humor que aponta diretamente para a crítica e denúncia de um sistema político e social. Nesse contexto, entretanto, a pena satírica da autora possui uma particularidade, a leveza, uma vez que, se não houvesse alternância dos dois planos narrativos, o da sátira social e da individual e psicológica, seria instituída a monotonia e o didatismo, assim como o tédio no leitor. 
A crítica Emily Toth pronunciou que somente no Algonquin Round Table, e mesmo este tendo seus limites, uma mulher poderia dizer exatamente o que pensava e ser considerada espirituosa ao invés de monstruosa. Para ela, as regras sociais para as mulheres são muito bem representadas neste conto: às mulheres era exigido que agradassem aos homens. (1977, p. 123) Dessa forma, o alvo satírico de Dorothy Parker não se trata do jovem desajeitado ou da mulher que é importunada, mas são as regras sociais às quais eles estão amarrados, ou seja, os sentimentos e hipocrisias de uma sociedade patriarcal, que sua crítica última é destinada.

\section{As duas "vozes"}

Em "The Waltz", podemos observar que a voz exterior é esteriotipadamente feminina. Para Sondra Melzer, isso se dá por manifestar a maior parte das características que Robin Lakoff atribui a uma "linguagem das mulheres". (1997, p. 101) Isso pode ser observado como um modo de encobrir a identidade feminina, negando a ela a possibilidade de se expressar mais verdadeira e profundamente e encorajando a trivialidade. Por exemplo, as muitas vezes que a personagem repete palavras como "simply", "really", “trully". Também a grande presença de advérbios e adjetivos, assim como perguntas e repetições que denotam condescendência e acomodação. “Yes, it's lovely, isn't it?” Ela diz repetidamente, “It's simply lovely. It's the loveliest waltz. Isn't it? Oh, I think it's lovely too" (p. 211) ("É uma delícia, não é? É simplesmente uma delícia. Não é uma valsa deliciosa? Oh, eu também estou achando uma delícia.”) (p. 22) Também podem ser observadas interjeições tipicamente femininas, como "oh”, “oh, yes”, “oh, no, no, no”, "oh goody", "oh darn”. A personagem se coloca de forma subordinada a seu parceiro, escondendo seu desagrado com a dança, seu cansaço e suas vontades: "Oh, they're going to play another encore. Oh, goody. Oh, that's lovely. Tired? I should say I'm not tired. I'd like to go on like this forever." (p. 211) ("Olhe, vão tocar mais uma. Oh, que ótimo. Que delícia. Cansada? Não, nem um pouco. Poderia continuar dançando pelo resto da vida.”) (p. 23)

Já em sua voz interior, a linguagem é marcada pela impolidez e pela agressividade e ódio que sente dele e da situação: I wonder what I'd better do - kill him this instant, with my naked hands, or wait and let him drop in his traces. (p. 210) ("O que será que devo 
fazer: matá-lo neste exato momento, com minhas próprias mãos, ou esperar que ele tenha um infarte em poucos segundos?) (p. 21)

A comicidade reside justamente na essência da linguagem desses dois locutores que parecem distintos, a mulher frágil e exageradamente feminina e a voz masculinizada, agressiva e bruta. Trata-se da incongruência entre um conceito e a sua aplicação na prática, o que para Shopenhauer seria a base de toda citação de humor.

No quinto monólogo, vemos que o efeito cômico, assim como o desespero da personagem, se propagam por auto-acumulação. Ela exclama definitiva:

I hate this creature I'm chained to. I hated him the moment I saw his leering, bestial face. And here I've been loked in this noxious embrace for the thirty-five years this waltz has lasted. Is that orchestra never going to stop playing? Or must this obscene travesty of a dance go on until hell burns out? (p. 211)

Detesto essa criatura à qual estou atrelada. Detestei-o desde o momento em que vi o seu olhar de soslaio naquele rosto bestial. E agora me vejo travada nos seus braços pelos 35 anos que esta valsa está durando. Será que a merda da orquestra nunca vai parar de tocar? Ou essa coisa ridícula a que chamam de dança vai durar até o quinto dos infernos? (p. 23)

Em dado momento ela se questiona, respondendo com ironia a uma indagação que o próprio leitor se faz: Se ela sofre tanto, porque simplesmente não se desvencilha da dança? Ela pondera enquanto continua a bailar:

I wonder why I didn't tell him I was tired. I wonder why I didn't suggest going back to the table. I could have said let's just listen to the music...Still, if we were back to the table, I'd probably have to talk to him. (p. 212)

Não sei porque não lhe disse que estava cansada. Porque eu não sugeri voltarmos à mesa? Poderia ter dito, vamos apenas ouvir a música, que tal? ... O problema é que, se voltássemos para a mesa, teria que conversar com ele." (p. 23)

Para ela, conversar com ele seria ainda mais doloroso do que a dança. Ela continua a ridicularizar seu parceiro, denotando sua raiva encubada, e tomando o leitor como aliado: "Look at him - what could you say to a thing like that! Did you go to the circus this year, what's your favorite kind of ice cream, how do you spell cat?" (p. 212) (“E o que eu poderia perguntar a uma mula dessas? Já foi ao circo este ano? Qual é o seu sorvete favorito? Como você pronuncia gato?”) (p. 24). 
É criada, com isso, uma imagem cada vez mais patética do homem que foi até ela lhe tirar para dançar. Ele não tem escapatória, nem chance de defesa. Segue-se então o discurso da personagem que, entorpecida, relembra situações horríveis que passou e as compara à situação que se encontra. É nesse momento que a orquestra pára de tocar.

Ela se recompõe e assume novamente sua personalidade externa, para surpresa do leitor que vislumbrava um fim para seu martírio:

Oh, they've stopped, the mean things. They're not going to play any more. Oh, darn. Oh, do you think they would? Do you really think so, if you gave them fifty dollars? Oh, that would be lovely. And look, do tell them to play this same thing. I'd simply adore to go on waltzing. (p. 212)

Oh, eles pararam de tocar, aqueles cretinos. Não vão tocar mais. Oh, droga. Você acha que eles vão voltar? Acha mesmo, se você lhes der 20 dólares? Oh, seria incrível! E, olhe, peça para tocarem de novo aquela mesma valsa. Eu poderia dançar com você pelo resto da vida. (p. 25)

Ao fim, a personagem adota sua retraída linguagem feminina de sobrevivência e se apega ao parceiro masculino, como sabe ser seu dever. Mais uma vez ela se entrega à realidade do repugnante poder masculino tão odiada por ela. O interessante é observar como ela reitera e incita essa situação. Ao pedir para que ele pague aos músicos, a personagem se subordina também economicamente, manipulando-o para ao menos extrair dele algo pelo seu sofrimento. A dança entre os sexos torna-se então interminável.

Críticas feministas como Nancy Walker, Emily Toth e Suzanne Bunkers consideram o humor presente na história como uma forma de protesto social contra o casamento convencional e aos costumes sociais que impõem restrições à autonomia da mulher. Em contraste a isso, a crítica Paula Treichler argumenta que os valores da história são cúmplices com o patriarcado, uma vez que a personagem sucumbe às imposições.

Quando o conto termina, porém, há um retorno às falas iniciais e o narrador é preso num círculo que ele mesmo se colocou. A história não possui um fim, nem mesmo um monólogo interno final que subverta a complacência da personagem. Esta consente em continuar a dança infinita e participa ativamente desse perpetuamento. Deste modo, a situação que era considerada hipócrita e intolerável é negada, uma vez que o leitor percebe não serem aqueles aos quais tinha acesso os verdadeiros sentimentos da personagem. Qual discurso é fiel ao seu caráter? O que será que ela sente "de verdade”? 
Ao deixar o final em aberto e, como diz Kant, resultar em "nada", a leitura múltipla possível em "The Waltz" se faz extremamente moderna e coerente com a história em si, tanto pela sua forma quanto pelo conteúdo, caracterizados pelo desequilíbrio e pela ambivalência.

Com os dois contos analisados nesse capítulo, “A Telephone Call” e "The Waltz", acompanhamos as frustrações e ansiedades de duas mulheres insatisfeitas, que se encontram paralizadas em seu descontentamento. No próximo capítulo, veremos como se comportam outras duas mulheres, Mimi e Maida, frente aos aborrecimentos apresentados. Além dessas duas personagens possuírem nomes, ambas estabelecem uma forte relação com o mundo exterior, sendo afetadas por ele e reagindo às imposições de sua época. Será a tomada de consciência e a reação feminina uma questão de tempo? 


\section{A MULHER E O MUNDO}

"The lamentable change is from the best; The worst returns to laughter." King Lear

A década de quarenta foi marcada, principalmente, pela guerra e suas conseqüências. O ataque japonês a Pearl Harbour em 1941 deu início à Segunda Grande Guerra, que por necessitar da força masculina, fez com que as mulheres tomassem seus lugares no mercado de trabalho.

O sucesso da penicilina revolucionou a medicina e o estilo de dança swing revolucionou as pistas. São anos nos quais a atividade de lazer favorita era o encontro no bar local após o trabalho para se ouvir a Juke Box por um níquel.

Parker colaborou com o roteiro do filme "The Little Foxes", adaptado da peça de sua amiga Lillian Hellman, e em 1944, junto a Alexander Woolcott, produziu a antologia do seu trabalho, como parte de uma série publicada pela Viking Press para os servidores localizados no estrangeiro. Com introdução de Somerset Mougham, o volume compilou duas dúzias dos contos de Parker além de poemas selecionados. Foi lançado nos Estados Unidos como The Portable Dorothy Parker.

Com o término da guerra em 1945, mudanças ocorreram no entretenimento. O racionamento teve seu fim, mas por um longo tempo o poder aquisitivo das pessoas se manteve pequeno. Foi nessa época, entretanto, que Fred Astaire e Ginger Rogers se tornam extremamente populares, assim como Gene Kelly. O humor, tão necessário principalmente em tempos difíceis, chegava rapidamente por meio do rádio, principalmente pelo talento de Bob Hope. Também o cinema se tornou um hit, com suas grandes estrelas como Clark Gable, Bette Davis, Joan Crawford, Marlon Brando, e muitos outros.

Os soldados retornaram para casa e havia muito a ser celebrado. Os Estados Unidos emergiam como uma superpotência, só comparável à União Soviética. Teve início então a Guerra Fria e cresceram as tensões diplomáticas e militares entre as duas superpotências da época. O comunismo era tratado como uma doença contagiosa, qualquer um que tinha algum contato com ele estava sob suspeita e o final da década de quarenta foi, então, marcado pelo inicio do Comitê de Investigação de Atividades Anti-Americanas, que tinha 
por objetivo investigar supostas atividades subversivas e erradicar a presença comunista na América.

O retorno dos soldados, a euforia e a suposta normalização da situação, porém, foi dotada de grandes mudanças, uma vez que os homens alistados tiveram contato com o resto do mundo, os negros não aceitariam mais ser diminuídos, e as mulheres, apesar de terem que retornar ao espaço doméstico, experimentaram a independência. Nada mais seria como antes.

Nos dois contos analisados a seguir, "The Lovely Leave" e "The Banquet of Crow", veremos a guerra do ponto de vista da mulher que fica à espera do seu soldado, e a “evolução" dos costumes por meio da história de uma esposa "abandonada". A autora procura desestabilizar o condicionamento externo ao qual as mulheres são submetidas, e usa o humor tão característico de seus textos, como uma crítica, se tornando uma sátira da sociedade.

\section{O Amor nos Tempos de Guerra}

O conto "The Lovely Leave" retrata o drama de uma mulher, temporariamente afastada de seu marido que se alistou para defender seu país, quando a visita dele é subitamente encurtada para que ele retorne aos serviços militares.

Mimi, assim como muitas mulheres em Nova York em 1943, acha a vida longe de seu marido Steve ociosa e cheia de tédio. Logo no início do conto, quando ele liga para ela, vemos que "She had not expected the call, and she had no words arranged." Não tendo preparado seu discurso, o narrador dá a entender que Mimi não saberia o que dizer a seu marido, espontaneamente. Neste momento, começamos a ter os elementos de uma personagem dotada de humor pela sua falta de segurança, de conhecimento principalmente sobre si, pela sua ingenuidade e sua total dependência do marido. Steve diz que fará uma visita na semana seguinte, e Mimi fica extasiada. "There will be no waste to this leave", ela promete a si mesma. Ela não vê o marido há dois meses, e sua visita anterior, a primeira vez que ela o viu em seu uniforme de tenente, terminara em uma briga. Ela silenciosamente determina, então, que as vinte e quatro horas que eles terão juntos serão redimidas em perfeita união. 
Durante a semana, Mimi prepara cuidadosamente a chegada de Steve. Ela compra um vestido preto novo ("he like black dresses"), uma linda camisola, os biscoitos preferidos dele, e seis arranjos de flores. Também nos é informado pelo narrador que mesmo se Mimi ficasse sem comer na semana seguinte por causa da extravagância nos gastos, valeria a pena. O exagero denota sua triste condição, a torna passível de julgamento, e de humor.

Quando Steve chega, ele traz a perturbadora notícia que sua visita será mais curta do que o previsto. "We're to go right on to the new field. I've got to get a train at six-ten", ele anuncia. A expectativa dela é então frustrada. Com o grande desapontamento de Mimi, eles discutem e, em um esforço para evitar o confronto e aproveitar por alguns instantes o conforto de casa, Steve decide tomar um banho, ler uma revista, e gastar seus últimos minutos polindo a fivela de seu cinto, o que provoca em Mimi mais uma decepção. Quando é chegada a hora de Steve ir embora, ele fala com dificuldade sobre seus sentimentos, dizendo a Mimi que ele "pertence" a ela, apesar de seu trabalho. Ela corre para seus braços abertos quando ele está saindo, e quando uma amiga liga momentos depois para saber da visita ela responde aos consolos da amiga sobre o imprevisto dizendo, "I know it wasn't very much time. But oh, it was lovely".

Um ano depois do conto ser escrito, em 1944, Dorothy Parker publicou, na revista The New Yorker, seu último poema, "War Song", retratando um soldado americano fazendo amor com uma garota estrangeira, como parte das expectativas de romance em tempos de guerra. Com uma visão liberal, a autora isenta os soldados do comprometimento com o celibato, porém afirma sua necessidade de afeto:

Soldier, in a curious land All across a swaying sea,

Take her smile and lift her hand Have no guilt of me.

Soldier, when were soldiers true?

If she's kind and sweet and gay,

Use the wish I send to you

Lie not lone till day!

Only, for the nights that were, Soldier, and the dawns that came, When in sleep you turn to her Call her by my name.

"The Lovely Leave" apresenta um ponto de vista diferente em relação ao poema. Podemos perceber no conto os diferentes modos como mulheres e homens lidam com o 
afeto e a emoção. Inicialmente, a resposta emocional da personagem Mimi à ausência de seu marido em função da guerra pode parecer egoísta, possessiva, e até mesmo patética.

Nosso primeiro contato com os sentimentos privados da personagem se dá na primeira cena. Ela embala o telefone que acaba de trazer a notícia da iminente visita dele, ela olha para o objeto "as if all frustration and bewilderments and separations were at its fault." O telefone, elevado a uma importância simbólica, traz a ela a voz que tanto almejava ouvir, mas uma voz que considera afobada. As vozes alegres e jovens que pode ouvir ao fundo, familiares a ele e não a ela, são as vozes daqueles com os quais seu marido divide sua nova vida. Quando ela o implora mais um minuto de conversa, Steve atende aos pedidos das outras vozes, e não ao dela, terminando a ligação. Os detalhes da passagem seguinte advertem a isso: She took her hand off the telephone and held it away from her with the fingers spread stiffly apart, as if she had touched something horrid. (p. 275)

O telefone lhe provoca sentimentos de horror. Mimi claramente exagera, dramatiza, atribuindo um significado mais profundo à maneira brusca de Steve.

Porém, imediatamente, ela parece recobrar a consciência, denotando lucidez e gerando comicidade por meio dessa dualidade extrema de sentimentos. Um exame mais detalhado dos pensamentos imediatos da personagem mostram sua clareza de raciocínio:

If you look for things to make you feel hurt and wretched and unnecessary, you were certain to find them, more easily each time, so easily soon, that you did not even realize you had gone out searching. Women alone often developed into experts at the practice. She must never join their dismal league." (p. 275)

Fica evidente, no entanto, que Mimi não conseguirá seguir esses preceitos, pois ela já sofre. O desastre da visita anterior de Steve foi resultado de sua insegurança, pensa ela, e do tempo valioso que ela estragou relutando com sua partida. A discussão que tiveram nas últimas horas da visita, que deixou Steve muito nervoso, proporcionou uma despedida fria e formal, deixando Mimi de coração apertado. Enquanto Steve voltava para seu trabalho, Mimi se remoía em lembranças e culpa. O narrador informa:"Then she had two months to ponder what had happened, to see how she had wrought the ugly small ruin. She cried in the nights." (p. 277)

O narrador parece compartilhar da opinião de que a culpa pelo fracasso do encontro anterior foi de Mimi, e coloca a expectativa e possibilidade de mudança também em suas mãos. Esta foi a primeira vez que eles, casados há pouco tempo, se separaram. Como se 
dependesse somente dela o sucesso do encontro, Mimi se alegra em ter uma segunda chance, que não pretende desperdiçar.

Apesar de sentir que a "nova vida" de Steve como oficial do exército representa uma ameaça não pronunciada para seu casamento, ela tenta se consolar pensando melodramaticamente: For how many people are there who have the memory of a whole long day and a whole long night, shining and sweet, to carry with them in their hearts until they die? (p. 277)

Ela considera que, talvez, a "estranha nova vida" e as "estranhas vozes alegres" não existam para "duas pessoas que são na verdade uma só”.

Com atenção redobrada em cada detalhe, Mimi se mostra extremamente confiante na preparação de uma atmosfera atraente e sedutora. O vestido caro, os materiais para coquetéis, whisky, soda, perfume e óleo para banho compõem seu arsenal feminino. É particularmente irônico que no dia da chegada de Steve, Mimi canta, enquanto se arruma no quarto, com sua voz descrita como doce e suave uma vigorosa canção masculina:

Off we go, into the wild blue yonder,

Climbing high into the sun, sun, sun,

Here they come: zooming to meet our thunder

At 'em boys, give 'er the gun! (p. 279)

Ela, paradoxalmente ao seu ciúme e raiva, se orgulha da condição do marido. Isso fica claro em dois momentos, quando caminha pelas ruas e olha com pena para as mulheres cujos maridos usam trajes civis, e quando liga para a portaria para avisar que, quando seu marido chegar, o Tenente McVicker, é para deixarem-no subir. O narrador diz que não havia necessidade para a ligação, a não ser sua vontade de dizer "meu marido" e "tenente". O paradoxo é considerado por Vladimir Propp (1992) um dos instrumentos linguísticos da comicidade, e essa alternância de sentimentos da personagem: amor, ódio, raiva, compaixão, orgulho, desprezo, que se sucedem, a tornam não somente provida de humor, mas também criam uma maior identificação com o leitor, provocando também neste sensações de compaixão, desprezo, raiva, etc. É o que confirma a crítica literária Nina Miller:

Parker undercut her own ascension to muse or loved object through her irony, a stance built into her subcultural imperative to perform as a humorist. More important, in sacrificing the sober intensity of romantic love to humor, she broke up the loving dyad with the implied intervention of her audience, for whom the jokes were staged. Thus triangulated, the 
lovers lose the psychodynamic logic supporting their lopsided interrelation. Humor about love-not the dramatic irony attending the spectacle of bunglers but the acerbic wit of a sophisticated lovernarrator-has the power to rupture the charmed circle of intersubjectivity by constructing its audience as a complicitous third party to the ridicule of one lover (the man) by the other (the woman). ${ }^{18}$

Quando Steve finalmente chega, a expectativa no leitor está criada. Porém, somos surpreendidos pela reação da personagem, que, numa tentativa de disfarçar sua solidão com uma cordialidade espirituosa, não deixa que ele a beije na boca e diz:"Nice to see you, Lieutenant. How's the war?"

A formalidade e distância que a personagem tanto queria evitar são por ela mesma impostas, e essa incongruência é fonte de humor. Steve, então, também evita contatos mais íntimos com a esposa. Quando diz a ela sobre o imprevisto da visita e que terá somente uma hora para voltar ao trabalho anuncia "This is the Army, Mrs. Jones" e "There's War On". Ao assumir essa postura, Steve faz transbordar a raiva incubada de Mimi por seu afastamento de sua vida. Os constantes comentários de Steve sobre as dificuldades de seu trabalho e sua admiração por seus companheiros a incomodam cada vez mais.

É perceptível o sentimento de amor que nutrem um pelo outro, porém, quando em contato, invariavelmente um deles age ou fala algo de natureza egoísta que provoca raiva e agride o outro. A inaptidão e o constrangimento na relação que foi estabelecida tomam o lugar do entendimento mútuo que seria crucial neste momento. Por exemplo, quando Steve tenta tardiamente elogiar seu vestido preto, e comete uma gafe dizendo que sempre a achou linda nesse vestido, Mimi, que o comprara especialmente para a ocasião dispara acidamente "I almost wish I were in it for another reason." Além da ironia, a graça também reside na infantilidade do comentário. Quando ele sugere que ela é "boba" por não sair com amigos homens, ela retruca: "It hadn't occurred to me...that it was silly to be faithful to one's husband". Diante do exagero da esposa, Steve surpreendentemente se mostra mais liberal que Mimi, encorajando-a a sair: "It's possible to go dinner with a man and stay this

\footnotetext{
${ }^{18}$ Parker destrói sua própria ascensão ao objeto amado por meio de sua ironia, um ponto de vista culturalmente autoritário construído para cumprir seu papel de humorista. Ainda mais importante, ao sacrificar a intensidade sóbria do amor romântico ao humor, ela rompe a díade amorosa com a intervenção subentendida do leitor, para quem as piadas são destinadas. Com a triangulação os amantes perdem a lógica psicodinâmica que serve de apoio à sua interrelação desequilibrada. O humor sobre amor - não a ironia dramática a serviço de uma exibição negligente, mas uma sagacidade amarga de um narrador-romântico sofisticado - tem o poder de romper o círculo encantado de intersubjetividade por colocar seu leitor como uma terceira parte cúmplice do ridículo amor de um (a mulher) pelo outro (o homem). MILLER, Nina. op. cit., 1999, p. 124 (Tradução nossa).
} 
side adultery". Porém logo a repreende nos seus modos: “And don't use words like one's. You're awful when you're elegant."

Podemos ressaltar neste ponto, mais uma vez, o antagonismo em relação à posição apresentada no poema "War Song", admitindo Parker, dessa forma, diferentes pontos de vista, que podem ser observados como o seu posicionamento pessoal libertário, enquanto autora do poema, e um posicionamento mais conservador, que procura representar as mulheres de uma forma generalizada, por meio da personagem do conto.

Enquanto Mimi deseja elogios e demonstrações de afeto, Steve aprecia os prazeres de se sentar em uma cadeira confortável, de ler uma revista, e tomar um banho quente. Essa incongruência de expectativas e vontades dos dois personagens também provoca o riso. Mimi decide revelar então o ressentimento escondido pela devoção de Steve ao Serviço Militar."You have a whole new life," ela conclui, "I have half an old one...I don't see how they're even going to come back together". Suas reclamações focam não só a nova vida de Steve, que parece adorar seu trabalho e seus companheiros, mas também sua negligência ao casamento desde que assumiu o serviço. Mimi faz referências sutis, porém cáusticas a Steve por não escrever para ela, e se ofende com a sugestão de que deveria sair com amigos, principalmente quando ele diz que ela deve estar passando por momentos difíceis, mas está provavelmente sentindo muita pena de si mesma.

Somente em um momento percebemos que Steve espontaneamente age com paixão amorosa. E neste momento o leitor é provido de uma especulação por parte da personagem feminina. Em resposta ao comentário de Steve de que ele gostaria de pensar que Mimi estava passando por bons momentos enquanto ele está ausente, ela o beija na testa e dispara, se referindo a uma suposta traição da parte dele: "You are a far nobler character than I am. Either that, or there is something else in back of this."

Vemos aqui que Mimi não é tão ingênua assim, e que parte de sua raiva incubada provém da desconfiança em relação à fidelidade do marido. Steve responde brincando a essa provocação infundada: "Oh, shut up". Ele então a puxa e seus corpos se encontram. O encontro caloroso dos corpos, porém, se encerra abruptamente com um empurrão, pois Mimi percebe que durante esse gesto, que poderia se desenrolar em mais afeto, Steve estende o pescoço para olhar seu relógio. Aqui, mais uma vez o riso surge pela expectativa frustrada. Ele se justifica, constantando que eles têm pouco tempo juntos e quando ela novamente se sensibiliza, é a vez dele de repeli-la, dizendo querer tomar um banho. 
Quando pergunta se ela não se importa, ela responde diretamente: “Oh, not in the least. I'm sure you'll enjoy it. It's one of the pleasantest ways of killing time, I always think."

A ironia amarga esconde o fato de que, tanto física quanto verbalmente, Mimi é impedida de se expressar verdadeiramente. A sexualidade é também ressaltada, uma vez que ela almeja ser desejada sexualmente, e sua camisola, cuidadosamente colocada na poltrona é totalmente ignorada.

Em desespero com o desinteresse de seu marido em relação a ela, Mimi é levada a uma forte manifestação não verbal: "She went over to the bathroom door, drew back her right foot, and kicked the base of the door so savagely that the whole frame shook." Steve mal ouve o barulho e pergunta se ela quer alguma coisa. Ela responde com amargo sarcasmo: "Nothing whatever. I've got everything any woman could possibly want, haven't I?"

Observamos, com estes exemplos, o modo como a comédia resulta do caráter da personagem. Esta, durante a história, censura certas condutas e logo depois dá exemplo delas. Para Bergson, esta é uma das formas da comicidade das palavras e das variedades possíveis do espirituoso. Trata-se de se deixar levar, por um efeito de rigidez ou de velocidade adquirida, a dizer o que não se queria dizer ou fazer o que não se queria fazer. (2004, p.110) Essa contradição, em que a personagem se encontra, denota sua inconsistência, e conseqüentemente gera humor.

Nesse caso, porém, sua rigidez e insociabilidade possuem raízes mais profundas. É extremamente importante analisar como e por que o amor e a solidão de Mimi foram transfigurados em ressentimento e ciúme. Parte da resposta pode ser encontrada ao examinarmos a divisão em que a personagem se encontra entre uma mulher passional e emocional, que entra em conflito com a esposa obediente e submissa. São essas duas identidades que fazem com que Mimi não tenha domínio sobre suas próprias reações, oscilando entre os diferentes papéis.

Uma das preocupações de Parker na história são os recursos verbais permitidos a uma mulher para a expressão sincera de seus sentimentos, tanto física quanto emocionalmente. A ironia, que, de acordo com Propp (1992), vem a ser a expressão de um conceito através de palavras, e o subentendimento de outro, contrário, aparece como meio para demonstrar verdadeiramente os sentimentos da personagem. 
Essa dualidade tem relação direta com o delicado balanço entre o que é proibido e o que pode ser dito, de acordo com os paradigmas de uma sociedade ainda patriarcal. Como esposa de um soldado, Mimi luta para ser heróica, cumpridora de seus deveres com o marido alistado. Ela diz explicitamente:

There had been rules to be learned in that matter, and the first of them was the hardest: never say to him what you want him to say to you. Never tell him how sadly you miss him, how it grows no better. How each day without him is sharper than the day before. Set down for him the gay happenings about you, bright litle anecdotes, not invented, necessarily, but attractively embelished. Do not bedevil him with the pinings of your faithful heart because he is your husband, your man, your love. For you are writing to none of these. You are writing to a soldier. (p. 277)

O papel do homem aqui também aparece dividido. O marido, com quem ela tinha intimidade, não mais existe: ele agora é um soldado e deve ser tratado e respeitado como tal. Verificamos que essa idéia é confirmada por ele, pois quando ela tenta expressar seus medos e seu ciúme, estes são repelidos por Steve que, irritado, pensa serem inapropriados e sem sentido: "You see, I don't know what to say, when you start talking about showing me glimpses of your heart, and all that" (p. 283)

Mimi entende as regras, ela nunca lhe escreveu uma carta se queixando, ou triste, ou brava. Ela imagina que se suas cartas forem cuidadosas, se ela se mostrar como ele gostaria que ela fosse, como recompensa, quando eles estiverem juntos, não haverá atritos. Seria como se eles nunca tivessem se separado. Ela reza para conseguir controlar o que sente: "Please keep me from doing wrong things. Please let it be lovely." (p. 279)

Trata-se de costumes impostos pela sociedade quanto à maneira que uma dama deve se portar. Mais importante ainda, a maneira como a mulher de um soldado deve se portar. Não conseguindo ultrapassar essas imposições, sua impotência se revela de forma cada vez mais irônica e agressiva.

Um ponto interessante a ser destacado é o nome da personagem, Mimi, que parece ter uma função, podendo ser lido como uma repreensão à demasiada atenção da personagem em si mesma. Entretanto, é fato que, relegada ao papel submisso de tolerância e silêncio, proibida de expressar seus sentimentos na sua totalidade, por serem considerados uma traição ao esforço da guerra, Mimi se tornou uma estranha. O "tenente", como ela repetidamente se refere a ele, é também um estranho, e a timidez que ela sentiu 
quando o viu pela primeira vez com uniforme, e que se repetiu nesta segunda visita, se mostra sintomática da alienação da vida de seu marido, que acontece de forma destruidora.

Esta alienação pode ser verificada em diversas sutilezas. A linguagem do exército, satirizada por Parker como uma forma de "linguagem masculina", exclui Mimi dos pontos de referências mais básicos de Steve, como quando ele procura por um pano para polir a fivela de seu cinto. Aqui também vemos presente a virilidade masculina, que é deslocada dos carinhos de sua esposa, para um objeto de vaidade perante seus companheiros: "Hell, I don't suppose you've got a Blitz Cloth, have you? Or a Shine-O?" (p. 285)

Ela responde deslocada, porém provocadora: "If I had the faintest idea what you were talking about," she said, "I might be better company for you." (p. 285)

Ao escolher um vocabulário exclusivamente masculino, Steve mantém seu domínio sobre Mimi, encoraja sua inabilidade e nega a ela a igualdade na relação.

O longo discurso de desabafo de Mimi para Steve denota sua profunda confusão emocional na relação e com os efeitos provocados pela guerra. Em uma exposição madura e honesta em termos de linguagem, Mimi advoga por si mesma e por qualquer mulher que tenha se sentido rejeitada ou posta de lado por homens cuja dedicação por causas masculinas tornaram trivial sua importância:

I'm trying to tell you something. Just because you've got on that pretty suit, you think you should never hear anything serious, never anything sad or wretched or disagreeable. You make me sick, that's what you do? ... I realize what you're doing, I told you what I think of it. Don't for heaven's sake, think I'm mean enough to grudge you any happiness and excitement you can get out of it. I know it's hard for you. But it's never lonely, that's all I mean. You have companionship no-no wife can ever give you. I suppose it's the sense of hurry, maybe the consciousness of living on borrowed time, the-the knowledge of what you're all going through together that makes the comradeship of men in war so firm, so fast. But won't you please try to understand how I feel? Won't you understand that it comes out of bewilderment and disruption and-and being frightened, I guess? Won't you understand what makes me do what I do, when I hate myself while I'm doing it? (p. 286)

Esse discurso pode ser considerado o âmago da história, um lapso de verdade e sinceridade. Um apelo comovido e tocante é a retórica de uma mulher inteligente e sensível que deseja ser ouvida. Apesar de correr grandes riscos com a exposição, Mimi levanta uma série de questões femininas importantes que não consegue mais evitar. Em primeiro lugar, ela ataca a atitude chauvinista de Steve, que possui imunidade automática 
dos sentimentos dela enquanto está de uniforme, e o fato de que uma relação honesta entre uma mulher e seu soldado é quase impossível durante o período de guerra. Ela sabe que as mulheres possuem uma vida mais "fácil" durante a guerra, mas ela também sabe que os homens parecem desenvolver um excitamento peculiar pela vida armada, o qual ela percebe, e sabiamente não inveja. Mas é na questão do companheirismo que ela se coloca mais fortemente. A pressão do tempo, a urgência, a importância do que estão passando juntos, e a ameaça que paira sobre eles são razões suficientes para unir os homens em um laço que não pode ser desafiado, nem mesmo por sua esposa.

Reconhecidamente, esta é a origem de seu ciúme, seu medo e seu ressentimento: a vida e o amor que ele possui por seus parceiros enquanto ela está sozinha, o medo de perdê-lo, e o ressentimento por ele a ter rejeitado em face a essa nova vida, rompido com a antiga que tinham em comum, e a colocado para longe como uma estranha emotiva, uma mulher histérica incapaz de partilhar ou entender um soldado. Trata-se de um discurso corajoso, evidentemente feminino e pode ser considerado um dos retratos mais verdadeiros e claros das emoções de uma mulher no repertório de Dorothy Parker.

Em 1944, Dorothy Parker escreveu um impetuoso artigo intitulado "Who Is That Man?" baseado nas mesmas apreensões de estranheza e alienação expressadas por Mimi em relação à seu marido soldado:

Who is this man, who will come back to you? You know him as he was,...But what will he be, this stranger who comes back? How are you to throw a bridge cross the gap that has separated you... what have you to offer him? There are pictures in his memory that he can never share with you... Make a friend out of that stranger from across the world. (VOGUE, July 1944)

Podemos notar, neste artigo, o esforço da autora em avaliar as diferentes perspectivas, e compreendemos o seu medo ao reconhecer a incompatibilidade de homens e mulheres que foram divididos e se tornaram distantes devido à guerra.

A imagem da vida de Mimi fragmentada, desorientada, inferiorizada e sem propósito fica explícita, porém o modo como Steve lida e entende suas súplicas é uma outra questão. Diante da sinceridade dela, vemos nele também uma verdade emocional.

Com olhos preocupados e nublados, ele consegue com dificuldade dizer: "I can't talk about it. I can't even think about it-because if I did I couldn't do my job. . . I want to be with you, Mimi. That's where I belong." (p. 287). 
Ao mesmo tempo em que suas palavras parecem genuínas e tocantes, justamente balanceadas entre a emoção e o dever, somos levados a decifrar o significado de suas ações. Quando ele abre os braços para Mimi, ela corre em direção a ele e a autora nos revela: "This time, she did not slide her cheek along his lips". Na sentença seguinte, Steve abruptamente já partiu. Apesar de parecer que sua ida é marcada de uma troca mútua de emoção real, o leitor é tocado pelo fato de que, mesmo no final, é Mimi quem corre para Steve oferecendo seu amor, enquanto ele permanece parado de braços abertos em um convite respeitoso.

Quando ele parte, Mimi volta sua atenção, e o interesse do leitor, às plantas, que são imagens recorrentes e simbólicas para a história. A repetição, de acordo com Bergson, é tanto mais cômica quanto mais complexa é a cena repetida e quanto mais naturalmente é conduzida (2004, p. 67). No início, cheia de excitamento e otimismo romântico com a chegada de Steve, Mimi diz não ter conseguido resistir às flores charmosas com suas "delicate parchment-colored inverted cups and their graceful magentabells".

Mais tarde, quando ele está no banho e ela cheia de raiva com a indiferença intolerável de seu marido, ela olha para as flores "with their dirty parchment-colored caps, their vulgar magenta bells". Finalmente, depois do abraço de despedida com Steve ela retorna seu olhar às plantas "touching delicately, tenderly, the enchanting parchmentcolored caps, the exquisite magenta bells". Claramente, a transformação estética das plantas no olhar da personagem são paralelamente metafóricas ao estado emocional interior de Mimi.

Será que a transformação ao final nos faz concluir que as imagens "touching delicately, tenderly, the enchanting parchment-colored caps, the exquisite magenta bells" anunciam um final feliz para Mimi? É verdade que na despedida ambos se abraçam em um adeus marcado por emoções confusas.

Comparada à silenciosa e fria despedida após a primeira visita de Steve, quando ele limpou a garganta e disse: "Guess, I'd better get going" enquanto Mimi permaneceu parada, olhando para ele, essa nova despedida traz causas legítimas para um pouco de felicidade. É dada a impressão, porém, de que os efeitos demorados do êxtase momentâneo e confuso de Mimi são subitamente encerrados pelo som áspero do telefone. Ao atentarmos para as respostas dadas quando a amiga do outro lado da linha oferece condolências pelo imprevisto da visita ter sido encurtada, percebemos que as palavras de Mimi mais uma vez 
não são verdadeiras nem honestas com seus sentimentos: "I know it wasn't very much time but oh, it was lovely!"

A falsidade de seu discurso mostra que Mimi, novamente em sua solidão, finge, não somente ao avaliar o passado, mas como estimativa do futuro. Ela mente tanto socialmente, quanto psicologicamente, uma vez que é efeito do mentir social viver conscientemente apenas a vida superficial de seu ser psíquico (PIRANDELLO, 1996, p. 157). Sua astúcia feminina, que a condicionou anteriormente a aprender as "regras", a proteger e ocultar, e a negar seus próprios desejos, autorizam-na agora a maquiar a verdade e transformar sua experiência em uma expressão particularmente feminina de conciliação, quando diz ilusoriamente: "But oh, it was lovely."

A sensação que fica para o leitor é de que no final nada foi verdadeiramente alterado, nem a personalidade das personagens, nem a relação entre elas.

\section{O Desejo de Vingança}

A década de cinquenta foi considerada uma época de transição entre o período de guerras da primeira metade do século XX, e o período das revoluções comportamentais e tecnológicas da segunda metade do século. Em meio à histeria anticomunista que prevaleceu nos Estados Unidos durante o fim da década de 1940 e início de 1950, a investigação anticomunista invadiu a vida pessoal e profissional de Dorothy Parker. A escritora foi alvo de Joseph McCarthy (1908-1957) e do House Un-American Activities Committee por suas posições políticas de esquerda e suposta simpatia pelo comunismo. Após Walter Winchell tê-la apontado ao FBI como "mad fanatic of the Commy party line," Parker foi colocada na lista negra. Muitos de seus amigos, incluindo Zero Mostel e Lillian Hellman, foram denunciados e até mesmo presos. Parker foi chamada a depôr, e após responder perguntas sobre suas atividades políticas relacionadas à ajuda que prestara à Espanha e ao movimento anti-nazista, ela invocou a quinta emenda, se recusando a responder perguntas que pudessem incriminá-la. Em 1955, após cinco anos, o FBI terminou as investigações e considerou a escritora não "perigosa" o suficiente para ser incluída no Security Index.

No final da década de quarenta, Simone de Beauvoir escreveu o livro intitulado $O$ Segundo Sexo, que denuncia as raízes culturais da desigualdade social. Nesta época teve 
início uma grande revolução comportamental como o surgimento do feminismo e dos movimentos civis em favor dos negros e homossexuais. Surgiram movimentos de comportamento como os hippies, com seus protestos contrários à Guerra fria e à Guerra do Vietnã.

Anos depois, em 1963, Betty Friedan, importante expoente feminista, apoiando-se nos postulados teóricos do estudo de Beauvoir, publicou A Mística Feminina, detectando o que chamou de "o mal que não tem nome". Isso pode ser traduzido como uma frustração constante e indefinida. Afinal, por que se queixavam aquelas mulheres, em suas cozinhas modernas, com seus carros na garagem, seus filhos saudáveis e segurança econômica? Como encaixar esta insatisfação na auto-realização que, teoricamente, deveriam sentir? Como conviver com uma frustração que se torna mais evidente quando, em sua maturidade, a mulher vê os filhos seguirem seu próprio caminho e a dimensão do vazio em sua vida se alargar?

Dorothy Parker, anos antes, já havia denunciado os costumes cultivados que subordinam a mulher pelo gênero, pela classe e pela raça em suas ficções realistas.

Em "The Banquet of Crow", escrito em 1957, a autora examina as consequências de um casamento de onze anos que termina quando o marido, Guy Allen, deixa sua esposa, Maida. Depois de anos de inúteis tentativas de conversas com sua esposa, a respeito de sua infelicidade no casamento, Guy Allen anuncia determinada noite: "I don't want to do this any more Maida, I’m through", e então sai pela porta, para nunca mais voltar.

"The Banquet of Crow" foi o último conto publicado por Dorothy Parker, e assim como o primeiro, "Such a Pretty Little Picture", lida com um casamento no qual a felicidade é somente uma aparência externa.

Em "Such a Pretty Little Picture", vemos uma mulher, Mrs. Wheelock, que é obsessiva com limpeza e ordem. O que de seu ponto de vista é uma virtude, ela prega botões antes mesmo deles caírem. Percebemos que sua agressividade e sua natureza dominadora são camufladas pela aceitável preocupação social do feminino com as tarefas domésticas, o que pode, como diz Simone de Beauvoir em "O Segundo Sexo", levar à perversão ${ }^{19}$. Já seu marido, Mr. Wheelock, é um homem sensível. É chamado de "daddy"

\footnotetext{
${ }^{19}$ Simone de Beauvoir se refere à raiva contra a sujeira, manchas e lama, como uma batalha obsessiva da dona de casa contra o pecado e o próprio Diabo: "The maniac housekeeper wages her furious war against dirt, blaming life itself for the rubbish all living growth entails... Severe, preoccupied, always on the watch, she loses joie de vivre, she becomes overprudent and avaricious. She shuts out the sunlight, for along with
} 
pela esposa e é constantemente ridicularizado por ela e pelos outros por não ter as habilidades que o "homem da casa" deveria ter, como cortar as plantas da cerca ou consertar o que quer que seja. Mr. Wheelock vive entediado com seu trabalho na cidade, com sua esposa dominadora e com sua filha enfadonha. Não há ninguém que o entenda, tem poucos amigos e suas relações carecem de importância. Ele é um homem frustrado e está aprisionado na vida que tem. Enquanto Mr. Wheelock permanece fixo nas amarras matriarcais de seu casamento sonhando em um dia partir, Guy Allen de "The Banquet of Crow" escolhe dar vazão às fantasias de fuga e liberdade. No fim desse ciclo com relação a casamentos falidos que Parker propõe, é o masculino que rompe com as convenções sociais, dando vazão a seus sentimentos e suas vontades, cabendo portanto agora às mulheres a responsabilidade de se libertarem do papel que lhes foi condicionado e darem mais atenção ao que verdadeiramente sentem e querem.

Enquanto "Such a Pretty Little Picture" é contado predominantemente a partir do ponto de vista do marido, em "The Banquet of Crow" a narração está mais interessada nas reações de Maida do que no abandono de Guy.

Neste sentido, o conto apresenta as maneiras como uma mulher procura se adaptar ao profundo desastre que é sua vida marital, sem adquirir a menor consciência de uma individualidade, existente fora da fábula do amor e do casamento. A personagem feminina afigura-se como uma manifestação clássica, o protótipo satírico da enfadonha mulher correta cujo abandono é previsível e merecido.

Ao longo da história, vemos os motivos e o modo como Maida contribuiu para o fim da relação.

Apesar da personalidade de Maida ser o elemento motor da história, somos guiados através da narração, ou seja, contada na terceira pessoa, a maior parte da história fala “sobre" Maida. É somente na terceira das cinco páginas do conto que Maida fala por si mesma. O leitor, entretanto, acumula muitas informações sobre a personagem, seu casamento, e o mundo em que ela vive.

Um ponto interessante a ser analisado é em relação aos nomes das personagens: Guy, que abrange conotações genéricas masculinas, e Maida, que remete a palavra maid,

that come insects, germs, and dust... She becomes bitter and disagreeable and hostile." Ela também diz que a compulsão por limpeza pode ter "um toque sexual", o resultado da negligência masculina que normalmente resulta em frieza e frigidez. DE BEAUVOIR, Simone. The second sex. Translated and edites by H. M. Parshley. New York: Knopf, 1953; reprint ed., 1974. 
que significa criada. Este simbolismo pode ser considerado, então, uma ferramenta autoral em relação à percepção dos papéis marido/esposa.

Com uma estrutura singular, a história começa metaforicamente com um panorama jornalístico da classe média-alta de Nova York, durante o fim dos anos cinquenta. Em um ritmo pontuado pela repetição, a sequiência inicial mostra uma imagem perturbadora de um período na América de apatia, desigualdades, futilidades e mudanças comportamentais:

It was a crazy year, a year when things that should have run on schedule
went all which ways. It was a year when snow fell thick and lasting in
April, and young ladies clad in shorts were photographed for the tabloids
sunbathing in Central Park in January. It was a year when, in the greatest
prosperity of the richest nation, you could not walk five city blocks
without being besought by beggars; when expensively dressed women
loud and lurching in public places were no uncommon sight; when
drugstore counters were stacked with tablets to make you tranquil and
other tablets to set you leaping. It was a year ... when husbands who
have come home every evening not only at the same hour but at the same
minute of the same hour came home one evening more, spoke a few
words, and then went out of their doors and did not come in by them
again. (p. 323)

Essa passagem se faz importante pois, neste ano, marcado pelos excessos, muitos casamentos foram desfeitos. Aliando esse fato ao individualismo, à falta de valores característicos da época, e à real dedicação da personagem em repetir incessantemente seu sofrimento, justifica-se o desinteresse dos amigos de Maida por suas lamúrias e a sua necessidade por ajuda de uma terapeuta "profissional".

O narrador adverte:

If Guy Allen had left his wife at another period, she would have held the enduring interest of her friends. But in that year of lunacy so many marital barks were pilled up Norman's woe that the friends had become overly familiar with tales of shipwreck. (p. 323)

Com o rompimento de suas amizades, que teve início quando uma senhora cansada de ouvir as queixas de Maida sobre o marido, bate com força sua xícara de chá e grita: "For Christ's sake, Maida, talk about something else", e segue com o cessamento dos convites para eventos e festas, Maida conclui ressentida que teve sorte em descobrir a tempo que essas amigas não lhe serviam: "in time for what, she did not state." Vemos neste momento a intervenção do narrador para comentar a história com ironia, o que acontece ao longo da narrativa, exaltando ainda mais a distância entre as atitudes da personagem e o que seria 
esperado dela. O sarcasmo presente na narração mostra uma mulher maçante, desinteressante, cuja falta de perspicácia contribuiu para sua própria infelicidade, assim como seu excesso de auto-piedade contribuiu para sua estagnação. Não havendo uma adaptação psicológica às mudanças, ela não se ajusta aos novos papéis sociais que vão exigindo dela nova postura, novas perspectivas e um outro comprometimento.

Desse modo, Maida passa a ser um peso para quem convive com ela, e se torna cômica. Podemos verificar nela um exemplo dos conceitos desenvolvidos por Bergson de superioridade do humor. Seu ideal é a elasticidade, a adaptabilidade, o élan vital. Portanto, o cômico é "algo mecânico encrostado sobre os seres vivos" (2004, p. 97). A personagem cômica típica, diz ele, é alguém com uma obsessão, ou idéia fixa, a personagem não é flexível o suficiente para adaptar-se às necessidades complexas e mutáveis da realidade. $\mathrm{O}$ riso passa a ser, então, a defesa da sociedade, neste caso os leitores, contra os excêntricos que se recusam a ajustar-se às suas necessidades, ou seja, Maida.

Ainda de acordo com Bergson, sendo o objeto do poeta cômico apresentar tipos (2004, p. 111), percebemos agrupados em torno da personagem principal, personagens secundárias que são cópias simplificas dela, apresentando, dessa forma, vários exemplares do mesmo tipo.

Neste conto, as mulheres que cercam Maida não são muito diferentes do seu modelo. A pequeneza de seus valores, suas vidas limitadas que giram em torno de rituais de chá da tarde e "pleasant little dinner parties", as fofocas constantes que fazem dissecando "the saga of the deserted", e a necessidade que elas possuem dos homens e da aprovação masculina, unem umas às outras no compartilhamento do enfado de suas vidas. Assim como as mulheres citadas no texto de abertura, estas não contribuem ativamente, nem respondem a uma estimulação intelectual ou crescimento social individualmente. Ao seguirmos a trajetória de Maida, analisamos seus diferentes níveis de alienação. Concluímos que ela não conhece verdadeiramente seu marido, nem a si mesma.

Quanto à descrição da personagem, sabemos ela ser bonita, e possuidora de, em suas próprias palavras: "proven talents as a wife, chum, and lover". A latente ilusão em que a personagem se coloca a torna cômica, como no contraponto entre o real e o ideal que transparece na seguinte passagem:

Her present became intolerable to Mrs. Allen, and she could see her future only as a hideous prolonging of it. She turned to the past. She did not led memory lead her; it was she who steered memory back along the 
sunny bypaths of the marriage. Eleven years of marriage, years of happiness ... perfect happiness. (p. 325)

Esta ilusão é rapidamente corrigida pela voz do autor onisciente. Friedman pontuou que o narrador oniciente atua de maneira favorável à brevidade, uma vez que ao ter conhecimento do todo, ele seleciona e manipula o material, omitindo o que não possui tanta importância para a história, e assim maximizando o efeito artístico. (apud MAY, 1976, p. 145)

O narrador profere ironicamente: “...if she had had eleven years of perfect happiness, she was probably the only human being who ever did".

Aqui percebemos que a observação cômica vai instintivamente para o geral. Bergson pontuou que o autor cômico escolhe, entre as singularidades, aquelas que são passíveis de reproduzir-se e que, por conseguinte, não estão indissoluvelmente ligadas à individualidade da pessoa, ou seja, singularidades comuns. Transportando-as para a cena, se distinguirão das outras obras de arte por seu caráter de generalidade, assim como pela intenção inconsciente de corrigir e instruir. (2004, p. 127)

Parker nos informa sutilmente, através do narrador, que havia sinais reais de problemas que Maida recusou ou talvez tenha sido incapaz de perceber. Ele retrata a linha de raciocínio da personagem, quando repensa seu casamento: "Guy had a man's little moods, sometimes, but she could always smile him out of them." Para Maida, esses minutos de estranhamento só fizeram com que eles se aproximassem mais, e um falso conforto é procurado na máxima: "lovers' quarrels wax the way to bed". Já ao avançarmos na história conhecemos a versão de Guy para o relacionamento que parou de lhe dar alegrias nos últimos seis anos, seu descontentamento e insatisfação: "I'd been saying it to you for six of those eleven years, but you interpreted it as a cry of Wolf".

A habilidade de Maida em não admitir a realidade, evitando lidar com os problemas e de se iludir criando fantasias, são sintomas de uma pesonalidade sem coragem, entorpecida pelo tédio, não acostumada a aprofundar raciocínios e com grande desconhecimento de seus sentimentos internos, ou seja, aqueles que ela não mostra aos que a rodeiam. Percebemos que seu casamento não só minou sua personalidade por meio de uma rotina tediosa, como minou também sua capacidade de perceber os efeitos disso em seu marido e na relação. 
No momento em que se vê sem seu marido e seus amigos, Maida, em sua solidão, esforça-se para definir o que pode ter acontecido para isso. O narrador oferece mais informações da superficialidade emocional e psicológica da personagem nas linhas que se seguem: "She wanted to find understanding - that thing so many spend their lives in seeking, though surely it should be easy to come upon, for what is it but mutual praise and pity." (p. 325)

Examinando atentamente, podemos perceber, porém, que não é a inocência das palavras que impressionam o leitor, e sim a ignorância.

A personagem, todavia, começa a mostrar alguns sinais de imaginação e entusiasmo, reunindo-se, mesmo com dificuldade, com um novo círculo de amigos. Nos íntimos encontros vespertinos em seu apartamento, as mulheres advertem Maida, ao invés de consolá-la. Elas a aconselham: "to buck up, pull herself together, to get on her toes" uma imitação de coloquialismos masculinos pelas recém surgidas mulheres de opiniões fortes e pensamentos livres. Quando uma mulher aconselha Mrs. Allen a mandar Guy para o inferno, ela interrompe as reuniões. Uma das convidadas, porém, é quem lhe apresenta a Dra. Langham.

Essa combinação de fatores antecipa em quase uma década personalidades do movimento feminino que estava por acontecer. As "intimate sessions at her apartment", as vozes agressivas de mulheres aconselhando Maida a enfrentar Guy em uma linguagem que evoca "fight talk in the locker room", e a brilhante psiquiatra Dra. Langham, são prenúncios críticos do amadurecimento da consciência dos anos setenta, as novas e ousadas identidades feministas e as mulheres profissionais liberais vindas da revolução feminina que também são satirizadas.

Foi neste mesmo ano de 1957, em que este conto foi escrito, que Dorothy Parker concedeu entrevista para Marion Capron (1957, p. 69-82) afirmando ser feminista, declarando sua preocupação e atenção voltadas para as desigualdades determinadas por gênero. Pouca atenção dos críticos foi dada a esse ponto de vista de Parker na época, mas este conto, em particular, reflete sua própria consciência feminista.

Neste sentido, se faz extremamente significativo a personagem do psiquiatra ser uma mulher. Dra. Marjorie Langham, esbelta, sorridente, segura de si, e com muito sucesso: "healer of troubled minds", se faz perfeita para Mrs. Allen. Uma mulher de raciocínio rápido e muita simpatia por membros do mesmo sexo, que diagnostica 
imediatamente o comportamento ultrajante de Guy ao abandonar sua esposa. Ela profere, mesmo sem estudar o caso com exatidão:"Those middle forties! That dear old dangerous age! Why, that's all that's the matter with him - he's going through the change."

Vemos que a linguagem feminina é satirizada por Parker logo nos comentários iniciais da Dra. Langham, ao se referir aos problemas de Guy como "dear old dangerous age," um conjunto de eufemismos refinados. Trata-se do primeiro diálogo identificável de uma determinada personagem na história. Ao invés de vermos colocada nessa personagem características condizentes com a revolução feminina que estava sendo fomentada, vemos também um tipo solidificado, uma mulher que aparenta ter as mesmas características de Maida quanto ao ressentimento dos homens e o mesmo desconhecimento sobre si e de como lidar com o outro.

Ao seguirmos as sessões de Maida com Dra. Langham, percebemos que seu maior talento é a habilidade de fornecer seu compadecimento, amizade, e soluções confortantes de imediato às preocupações de Maida, fazendo generalizações e reduzindo os problemas a simples questões. Não fazendo a personagem tomar contato com seus erros, suas dores e suas vontades, mais uma vez a possibilidade de mudança fica inteiramente a cargo da personagem principal, que, sem um verdadeiro auxílio, se mostra cada vez mais passiva.

A psicanálise encontrou seu apogeu nos anos 1950 e 1960, e Dorothy Parker usa este elemento externo para satirizar tanto o objeto desta análise, Maida, como seu próprio agente, Dra. Langham. O narrador nos informa, condenando o caminho confortável escolhido pela doutora:

Though Dr. Marjorie Langham earned her own living, she had lost none of her femininity- doubtless because she had never trod the bloody halls of medical school or strained her bright eyes studying for an M.D. With one graceful leap she had landed on her slender feet as a healer of troubled minds. It was a year when the couches of such healers had not time to grow cool between patiens. Dr. Langham was enormously sucessful. (p. 326)

Parker descreve Dra. Langham como uma mulher esteriotipada, de visão limitada no que se refere ao casamento de Maida. Sua noção de que Guy é um homem confuso de meia idade, de que ele está sofrendo pelo que fez, e de que ele retornará arrependido, se mostra claramente como um esforço para dizer a Maida somente o que esta gostaria de ouvir, pois Dra. Langham "had the ability to make wet straws seem like sturdy legs to the nearly submerged". Por sua vez, Maida credita inteiramente sua cura à terapeuta, uma vez 
que entende ser viável a explicação médica para o abandono do marido: menopausa masculina. Dra. Langham previsivelmente acena a cada relato de Maida sobre o comportamento ultrajante do marido, e quando esta conta a idade de Guy, a doutora esboça um sorriso confiante, e fundamenta: "He's going through the change... It's just the traditional case of temporarily souped-up nerves and the routine change in metabolism".

Maida imediatamente entra na fantasia e se sente uma tola por não ter pensado nisso antes, era evidente. Em seguida o narrador nos informa por entre parênteses, tornando cômico, e com isso desqualificando os postulados da terapeuta, que não lhe veio a memória, mas seus outros dois casos de pacientes com casamentos desfeitos, um tinha vinte e nove anos e o outro sessenta e dois.

O diagnóstico, entretanto, deixa Maida tão relaxada que ela se deita no divã. A garantia da terapeuta de que Guy está sofrendo, e cheio de vergonha e remorso, fortalece a convicção de que Maida é uma uma boa mulher e que sua paciência com seu marido rebelde de meia idade será recompensada após ele se desesperar para voltar para casa, envergonhado e humilhado. Dra Langham complementa seu trabalho, oferecendo a Maida livros escritos por autoridades femininas no assunto, que confirmam a idéia defendida pela doutora: "He knows what he did to you-he doesn't know why he did it, the way we do, but he knows. He's doing a lot of thinking about you. His not daring to call you up shows that." (p. 327)

As sessões com Dra. Langham, na realidade, distanciam cada vez mais Maida do contato com a realidade, pois não fornecem a ela o menor entendimento sobre si mesma. Sua aceitação em se manter segura e confortável continuam a impedí-la de uma verdadeira introspecção. Na realidade, podemos considerá-la tão isenta quanto em seus primeiros dias de autopiedade, o que parece ter havido é uma variação entre a depressão profunda e o falso otimismo, sem nenhum grau de auto análise. Neste caso, a comicidade presente, pela falta de consciência da personagem que permanece firme em seus propósitos, está apoiada e fundamentada em preceitos médicos. A doutora se faz extremamente importante para a história, uma vez que valida as atitudes e emoções de Maida. Se a Dra. Langham fosse realmente uma profissional competente, uma mulher independente fruto da emancipação feminina, certamente a evolução de Maida seria diferente e haveria uma grande possibilidade dela entrar em contato consigo mesma e crescer individualmente. Porém, se isso acontecesse, não haveria razão nem necessidade dessas duas mulheres serem personagens de um conto de Dorothy Parker. 
Apoiada integralmente pela doutora, então, Maida deixa de se considerar "the lone, lorn creature, rejected like a faded flower, a worn glove, a stretched garter". Ela agora sente-se "a woman brave and humane, waiting, with the patience that was her crown jewel, for her poor mudded man to get through his little indisposition and come home to her to be cheered through convalecence and speeded to recovery". Aqui, podemos verificar também o uso de clichês, uma das fontes do cômico textual, por exemplo nas metáforas invocadas pela personagem.

Ao projetar a culpa exclusivamente em Guy, ambas as mulheres implicitamente colaboram numa acusação sutil, porém vigorosa a todos os homens. Neste sentido, a história passa a girar em torno da raiva que ambas sentem dos homens em geral, e que se faz efetiva na visão carnívora de Maida: "the banquet of crow".

Enquanto o artista comum cuida do corpo somente, o humorista tem a função de cuidar do corpo e da sombra, expondo com minúcia a loucura de seus personagens (PIRANDELLO, 1996, p. 170). Vemos essa loucura acentuada na mudança da fúria passiva para a fúria ativa de Maida, que ocorre quando Guy liga para buscar suas coisas. $\mathrm{O}$ evento, já previsto por Dra. Langham que se gaba afirmando a ela "So there you are. And there he is. And who is the one who told you so?", promove um momento catártico para ambas as mulheres, uma possibilidade para a vingança armazenada. Nas instruções de Dra. Langham podemos perceber as sementes desses sentimentos:

Now listen to me. This is important. Maybe the most important part of your whole treatment . . . Remember that this man has put one of the most sensitive creatures I ever saw in my life through hell. Don't soften up. Don't fall all over him, as if he were doing you a favor coming back to you. Don't be too easy on him. (p. 328)

Com os direcionamentos dados por Dra. Langham, Maida profere suas primeiras e emblemáticas palavras diretas na história: "Guy Allen will eat crow”, e com isso dramatiza sua transformação. Dando continuidade a seu plano e resgatando a imagem convencional da mulher como objeto sexual, Dra. Langham insiste que sob nenhuma circunstância Maida deve pedir a Guy para ficar a noite toda. Ao que Maida notadamente responde demonstrando sua confiança: "Not for anything on this earth... If that's what he wants, he'll ask me. Yes, and on his knees".

O comportamento cada vez mais confiante de ambas as personagens as torna cada vez mais patéticas, passíveis de humor e de julgamento. 
Podemos perceber, contudo, que Maida se prepara para o encontro, comprando toneladas de flores quando retorna do consultório, e fazendo questão de dispensar a empregada.

Na cena em que Guy e Maida finalmente se encontram, uma possibilidade de reconciliação é proposta, apesar de Parker sinalizar ao longo da história que isso seria impossível. Se já constatamos que Maida tem muito pouca compreensão sobre si própria até agora, nesta cena o leitor perceberá que ela também sabe muito pouco a respeito de seu marido, exceto que uma determinada noite ele "spoke a few words" e a deixou supostamente para sempre. Ele agora vive no clube, envia a ela um cheque todo mês formalmente através de seu banqueiro, e está, de acordo com Dra. Langham, que nunca o viu, passando pela menopausa masculina.

A chegada de Guy ao apartamento para pegar suas malas é sua primeira entrada na história. A cena abrange a falta de comunicação e de entendimento das emoções que caracterizam a relação. Maida está extremamente confiante de que Guy vai voltar atrás em sua decisão. Já Guy, embora cordial, não esconde sua felicidade com a nova vida, nem disfarça sua intenção de abreviar o máximo possível o encontro e ir embora sem maiores incidentes. Maida tenta se manter calma e travar uma cordial conversa, mas logo foge ao controle dizendo "Why don't you sit down and tell me what was the matter with it here? Food? Shaving mirror? What?" Ao que Guy responde sem nem entender o questionamento "Why? Everything was fine." Vemos que a personagem está tão centrada em sua fantasia que nem percebe verdadeiramente o marido. De acordo com Vladimir Propp, a comicidade do caráter da personagem surge justamente dessa precariedade e insuficiência de qualidades positivas, manifestadas em seu comportamento, em sua mesquinhez e em sua procupação excessiva por si própria. (1992, p. 140)

Quando Guy levanta para pegar sua mala no quarto, Maida se força para não seguilo, evocando a Dra. Langham: "The doctor would surely consider it somewhat lenient, to go into the bedroom with him, the minute he came back".

Maida, porém, não evita tocar no assunto e provoca Guy, que parece sincero ao afirmar seus sentimentos. Quando do embate final, a oposição volta à tona. Foram para Maida realmente onze anos de perfeita felicidade, ou seu condicionamento e dependência simplesmente a fizeram se recusar a ouvir o que era desagradável e perturbador, e insistir no mito do casamento feliz? 
Esta pergunta é feita pela própria personagem na longa conversa que se segue: "Why are you unhappy?" she said. "Because two people can't go on and on and on, doing the same things year after year, when only one of them likes doing them," he said, "and still be happy." Maida não compreende ou não acredita nas palavras de Guy, e rapidamente volta sua preocupação exclusivamente para si:

"Do you think I can be happy, like this?" she said. "I do," he said. "I think
you will. I wish there were some prettier way of going it, but I think that
after a while- -and not a long while, either-you will be better than
you've ever been." "Oh you think so?" she said. "I see you can't believe
I'm a sensitive person." "That's not for lack of your telling me-eleven
years' worth," he said. "Look, this is no use. Goodbye, Maida. Take care
of yourself." "I will," she said. "Promise." (p. 331)

Ao atentarmos para esse diálogo, verificamos um traço de realidade e verdade não encontrado nas primeiras histórias de Parker. Destituído do habitual cinismo, essa cena é envolta particularmente na luta de duas pessoas que conviveram como estranhas por um longo tempo e tentam apreender um instante de comunicação, mesmo que Guy diga: “...this is no use..."

A noção de Guy de que no casamento somente um dos dois estava feliz, porém, não o exime do fracasso e da sua inabilidade de transmitir essa insatisfação. A pergunta de Maida: "Why were you unhappy?" não só não foi respondida, como permanece sem resposta. Ele diz somente que ela ficará melhor sem ele, talvez admitindo que não é ele a pessoa, e nem quer ser, a estimular seu crescimento como mulher. Talvez não seja coincidência também que o único feito criativo de Maida na história, a fantasia repulsiva do "banquete dos corvos", surge após o abandono de Guy. A seriedade da conversa é esvaziada, porém, quando Maida, após uma reflexão superficial, lembra Guy em tom de superioridade, enquanto ele espera o elevador, de seu verdadeiro problema: Ele está na meia-idade. Ao que Guy rebate consciente: "I wasn't middle-aged six years ago".

Este diálogo poderia ser um ponto de mudança para Maida, a chance de sua tomada de consciência, porém fica a cargo do leitor decifrar seu comportamento final. Ela, instruída pela Dra. Langham, age com "perfect coolness and sweetness", mesmo sendo ela, e não Guy, quem sofre. Entretanto, Maida não é mais uma vítima condescendente, ela racionaliza em sua dissimulação: "It must have been that Guy was still not over his common illness". Ele retornaria quando caísse em si, ela determina, e cria uma fantasia 
ainda mais elaborada de seu retorno: "shabby, broken down gnawing at a leg of cold crow, which she saw with all its feathers left on it, black and shining and disgusting".

Para Emily Toth, essa fantasia de Maida pode ser considerada um saudável produto de sua raiva: "...criativa, purificante, boa para a alma... Quando a história acaba ela saboreia essa deliciosa fantasia, palavras que ganham vida." ${ }^{20}$

Essa fantasia, assim como seu comportamento infantil, produzem um indiscutível efeito cômico, provocado principalmente pela inflexibilidade de caráter da protagonista. Ainda desenvolvendo a idéia de Bergson de que a vida muda constantemente, podemos dizer que a graça da personagem está em sua incapacidade de mudança de opiniões, de gestos e de palavras no decorrer de toda uma existência. Por se isolar na projeção de um mundo ideal calcado na fantasia de vingança, sua melancolia é punida com o riso, pois como já vimos, o riso tem esse traço preconceituoso de castigar as pessoas por seu caráter anti-social, uma vez que não há nada de engraçado no fato de a protagonista ter sido abandonada.

Podemos constatar, também, que neste conto o humor se dá no próprio relato, pelo constraste entre o que está escrito, e o que se forma na mente do leitor, quando este reflete sobre as falas das personagens.

Algumas vezes, os acontecimentos desdizem as informações fornecidas, como no caso das opiniões e previsões da Dra. Langham e em como Maida enxerga a si e a situação na qual se encontra. Outras vezes, a contradição se dá pelo contexto social implícito, de mulheres que não foram criadas para assumirem suas próprias vidas como Maida e daquelas recém "emancipadas" como a Dra, mas que ainda possuem uma consciência patriarcal, não contribuindo realmente para algum avanço, e pelo contrário, reforçando e incitando um comportamento equivocado.

Nas duas últimas frases, o narrador sentencia: "No. Fantasy was no good. She [Maida] went to the telephone and called Dra. Langham". Esse fim possibilita diferentes interpretações. A frase "No. Fantasy was no good" pode significar que a fantasia não era boa o suficiente, no sentido de que não era uma suficiente retribuição, e Maida vê na Dra. Langham uma aliada para ajudá-la a tramar uma vingança mais efetiva. Nesta interpretação, que nos parece a mais objetiva, mesmo sendo mostrada a impossibilidade de

\footnotetext{
20 “...creative, cleansing, good for the soul... As the story ends she is relishing that delicious fantasy, word made flesh." TOTH, Emily. op. cit., p. 78.
} 
concretização dos sonhos da personagem, ela continua, inflexivelmente, desejando pôr em prática, a todo custo, seus ideais, não havendo, dessa forma, qualquer tipo de transformação em seu caráter.

Todavia, "No. Fantasy was no good" pode significar literalmente que a fantasia fracassou. Existe a possibilidade de realmente ser o sinal do fim do longo romance de Maida com as ilusões, e sua ligação para a psiquiatra anunciar um gesto saudável em busca de uma vida mais real.

Maida, deste modo, não é uma personagem excêntrica, não são seus comportamentos que destoam. A personagem funciona como um espelho incômodo, risível quando olhado de fora. E é isso que faz com que o humor utilizado por Dorothy Parker seja moderno, explicitando a situação e não indo na contramão desta.

A imagem da fantasia punitiva predomina, então, os últimos momentos da história e o final enigmático pode ser considerado parte da estratégia da autora para não fechar um julgamento, sugerindo a complexidade e profundidade emocional de Maida em sua experiência enquanto mulher, e, como sempre, uma possibilidade de mudança.

Percebemos, então, que nos dois contos, "The Lovely Leave" e "The Banquet of Crow", assim como em "A Telephone Call" e "The Waltz" apresentados no capítulo anterior, apesar de terem sido escritos em décadas diferentes e tendo havido mudanças de comportamento na sociedade, a figura feminina continua dependente da figura masculina, da aprovação da sociedade, e confusa em relação aos seus próprios sentimentos. Mas não por muito tempo. Verificamos ser este o desejo de Dorothy Parker e o propósito de seus escritos. 


\section{CONSIDERAÇÕES FINAIS}

Essa dissertação analisou os contos “A Telephone Call”, “The Waltz”, “The Lovely Leave" e "The Banquet of Crow", relacionando a questão histórica e social da mulher com o uso do humor, assim como procurou dialogar com os poemas da autora e com outros contos que se fizeram relevantes para o propósito do trabalho.

Ao analisarmos a fortuna crítica de Parker, constatamos que alguns críticos a consideravam datada e superficial. O que se procurou demonstrar, no entanto, é que a autora trata de temas universais e de sentimentos atemporais como o ciúme, a rejeição, o amor, o desespero, a raiva; e utiliza o humor, considerado por alguns como indicador de superficialidade, de forma a mascarar discussões profundas e importantes como a dependência feminina e a insegurança da mulher em seu papel na sociedade. Parker apresenta personagens "tipo", ingênuas e até mesmo ridículas, para que a mudança de comportamento ocorra em quem com elas se identifica, ou seja, o leitor. Seus contos criticam duramente, então, não só a sociedade e os costumes impostos pelo patriarcado, mas a própria mulher que nada faz para que essa situação seja mudada.

Quanto ao aspecto formal de seus contos, podemos destacar, na análise dos textos, a utilização de diferentes técnicas, como o monólogo interior em "A Telephone Call”, os dois pontos de vista do narrador em "The Waltz", e o narrador onisciente e o diálogo em "The Lovely Leave" e "The Banquet of Crow".

Nos dois primeiros contos o que prevalece é a relação da personagem com a situação na qual está inserida e sua relação com o objeto de seu amor e de sua dor. No primeiro, sua insatisfação se dá por uma rejeição, enquanto que no segundo seu desespero provém justamente do oposto, da aceitação que tem por parte de alguém que não deseja. Nos outros dois contos, por sua vez, as personagens masculinas se fazem presentes, as personagens femininas se relacionam com o mundo exterior e esse mundo age sobre elas afetando seu cotidiano e suas emoções. Em “The Lovely Leave”, vemos a presença da Guerra e suas conseqüências para a relação amorosa de Mimi e, em "The Banquet of Crow", temos a presença da consciência feminista sendo formada e da psicanálise, muito em voga na época, representadas pela Dra. Langham, e diretamente responsável pela acomodação e passividade da personagem. 
Outra característica importante a ser pontuada é a escolha de Dorothy Parker pelo conto como gênero de escrita, uma vez que essa forma propicia um foco maior na situação e no conflito proposto. Por ser conciso, prende a atenção do leitor ao mesmo tempo em que lhe expõe uma situação clara e pontual. Percebemos em seus contos verdades reveladas por trás da vida superficialmente exposta e, ao criar finais circulares, sem resolução, a autora denota a modernidade de seus escritos com o propósito de melhor atingir seu objetivo, a crítica social.

Parker era considerada uma autora bastante popular e essa repercussão se dá também por pertencer ao Algonquin Round Table, um espaço que lhe permitia desenvolver seus talentos e suas habilidades sem censura ou restrições. Trata-se de um cenário que aliava inteligência e humor. Quando se fala em Dorothy Parker, a primeira imagem que é suscitada é a cômica, a autora era conhecida por seu humor ácido e suas citações sarcásticas.

Ao analisarmos as teorias sobre o humor percebemos muitas das técnicas do cômico aplicadas em seus escritos, como a repetição de falas da personagem em "A Telephone Call”, a personificação que a mesma faz com a figura divina e com o telefone, objeto de seu horror. Também verificamos o uso do exagero, da degradação, do esteriótipo que se faz bem evidente em "The Waltz", no qual a personagem alterna sentimentos, apresentando em sua linguagem externa expressões e comportamento típicos de uma moça nos moldes exigidos pela sociedade, enquanto internamente pragueja contra seu paceiro de dança e explode em raiva e gírias e violência. Já em "The Lovely Leave", a personagem é marcada pelo paradoxo, outra das ferramentas do cômico, uma vez que se orgulha da condição de tenente de seu marido, ao mesmo tempo em que sente ódio pelo mesmo motivo. Já em Maida de "The Banquet of Crow", vemos a rigidez e sua inflexibilidade de caráter como talvez a maior evidência da comicidade da personagem. Como teoriza Kant, todas as expectativas criadas em torno das personagens de Parker resultam em nada, uma vez que a incongruência se torna a marca registrada da maioria dessas mulheres que dizem uma coisa e fazem outra, não havendo assim nenhum movimento real e nenhuma tomada de consciência.

Suas personagens masculinas são apenas pretextos, homens hipotéticos, privados de palavras, existindo a fim de permitir a exibição das emoções femininas. Já suas personagens femininas são reais, nervosas e inábeis. Elas falam sozinhas, ou com quem quer que as ouça e tomam decisões quase sempre equivocadas. Essa criatura que Parker 
analisa é uma mulher rejeitada pela sociedade que começa a abandonar os ideais Vitorianos, uma mulher moderna atordoada pela liberdade recém-conquistada. Trata-se de uma sociedade em mutação, na qual os vínculos familiares e sociais se desatam. Nesse contexto, a mulher se encontra privada de referências, uma vez que fora educada sob o peso de regras que a sufocam e a projetam em um mundo no qual ainda não há lugar para ela. Em vão lhe dizem que agora pode decidir sobre seu futuro, mas os sentimentos que emergem são ainda conservadores, e ela se encontra paralisada. Sua dependência emocional em relação ao homem permanece intacta, e já que não lhe pode exigir mais nada, necessita de seu amor, infinito e incondicional.

A crítica Suzanne Bunkers ponderou:

In keeping with her purpose as a satirist, Parker's poems and short stories criticize the status quo rather than define new, three-dimensional female roles. It would be easy to conclude that Dorothy Parker is hostile toward the "simpering spinsters" or "rich bitches" she portrays in her poems and stories, but to do so would fail to take into account her satiric purpose and technique. Dorothy Parker is not satirizing women per se; rather, she uses her pitiable, ridiculous women character to criticize the society which has created one-dimensional female roles and forced women to fit into them. ${ }^{21}$

Desse modo, a autora, que se mostra à frente de seu tempo e preocupada com a condição das mulheres na sociedade, pode sim ser considerada uma humorista. Porém, como profere Henri Bergson, objetivando uma correção social. Como podemos perceber na temática de suas histórias e em suas personagens, Dorothy Parker será sempre uma grande expoente dos dramas e sentimentos femininos, ainda que estes provoquem risadas em quem os lê.

\footnotetext{
${ }^{21}$ Ao manter seu propósito enquanto sátira, os poemas e contos de Dorothy Parker criticam o status-quo da mulher ao invés de definir novos papéis tridimensionais para ela. É fácil concluir que Dorothy Parker é hostil em relação às "solteironas afetadas" e às "ricas miseráveis" que são retratadas em seus poemas e contos, mas fazê-lo seria desmerecer a importância da sua técnica e propósito irônicos.Dorothy Parker não satiriza a mulher sem razão, pelo contrário, ela usa personagens ridículas e dignas de pena para criticar a sociedade que criou um único papel para a mulher e a força a se submeter a ele." BUNKERS, Suzanne. 'I am outraged womanhood': Dorothy Parker as feminist and social critic. Regionalism and the Female Imagination, v. 4, p. 28, 1978. (tradução nossa).
} 


\section{REFERÊNCIAS BIBLIOGRÁFICAS}

\section{ObRAS EM ESTUdo}

PARKER, Dorothy. Big Loira e outras histórias de Nova York. Tradução Ruy Castro São Paulo: Companhia das Letras, 1987.

. Complete poems. Ed. Colleen Breeseed. New York: Penguin, 1999. . Complete stories. Introduction Regina Barreca. New York: Penguin, 1995. . Not much fun: the lost poems of Dorothy Parker. Introduction and compiled by Stuart Y Silverstein. New York: Scribner, 1996.

. The poetry and short stories of Dorothy Parker. New York: The Modern Library, 1994.

. The portable Dorothy Parker. Introduction Brendan Gill. New York: Viking, 1973.

\section{Algonquin Round Table}

BROWN, John Mason. The worlds of Robert Sherwood: mirror to his times. New York: Harper \& Row, 1962.

CASE, Frank. Tales of a wayward inn. New York: Frederick A. Stokes, 1938.

DOUGLAS, Ann. Terrible honesty: Mongrel Manhattan in the 1920s. New York: Farrar, Straus \& Giroux, 1995.

DRENNAN, Robert. The algonquin wits. New York: Citadel Press, 1968.

GAINES, James R. Wit's end: days and nights of the algonquin round table. New York: Harcourt, 1977.

HARRIMAN, Margaret Case. The vicious circle: the story of the algonquin round Table. New York: Harcourt, 1977.

HOFFMAN, Frederick J. The twenties: American writing in the postwar decade. New York: Macmillan, 1949. 
MILLER, Linda Patterson. Letters from the lost generation: Gerald and Sara Murphy and friends. New Brunswick: Rutgers University Press, 1991.

WILSON, Edmund. The twenties. Ed. Leon Edel. New York: Farrar, Straus \& Giroux, 1975.

\section{Bibliografia GERAL}

ABRAMS, M.H. A Glossary of literary terms. New York: Holt, Rinehart \& Wilson, 1961. ALVES, Bianca Moreira; PITANGUY, Jacqueline. O que é feminismo. Ed. Brasiliense, 1981.

APTE, Mahadev L. Humor and laughter, an anthropological approach. Ithaca, N.Y.: Cornell University Press, 1986.

ARISTÓTELES. Poética. Trad., pref., comentário e apêndices de Eudoro de Sousa. 3. ed. Rio de Janeiro: Imprensa Nacional - Casa da Moeda, 1966.

ATTARDO, Salvatore. Linguistic theories of humor. Berlin; New York: Mouton de Gruyter, 1994.

BERGER, Arthur Asa. An anatomy of humor. New Brunswick, N.J., U.S.A.: Transaction Publishers, 1993.

BERGSON, Henri. O riso. São Paulo: Martins Fontes, 2004.

BIER, Jesse. The rise and fall of american humor. New York: Holt, Rinehart and Wilnston, 1968.

BONE, Martha Denham. Dorothy Parker and New Yorker satire. Diss., Middle Tennessee State University, 1985.

BRANCO, Lúcia Castelo. O que é escrita feminina. São Paulo: Brasiliense, 1991.

BUNKERS, Suzanne. 'I am outraged womanhood': Dorothy Parker as feminist and social critic. Regionalism and the Female Imagination, v. 4, p. 25-35, 1978.

CALHOUN, Randall. Dorothy Parker: a bio-bibliography. Westport, CT: Greenwood Press, 1993. 
CÂNDIDO, Antônio. Literatura e sociedade. São Paulo: Companhia Ed. Nacional. 1965.

A personagem de ficção. Faculdade de Filosofia, Ciências e Letras da Universidade de São Paulo, 1963. (Teoria literária e literatura comparada, n. 2).

CAPRON, Marion. Dorothy Parker. In: BRADLEY, Malcolm (Ed.). Writers at work: the Paris Review Interviews. New York: Viking, 1957. Rpt. in PLIMPTON, George (Ed.). Women writers at work. New York: Penguin, 1989.

CORTÁZAR, Júlio. Valise de cronópio. São Paulo: Perspectiva, 1974.

COSTA, Iná Camargo. Panorama do Rio Vermelho. São Paulo: Nankin Editorial, 2001.

DE BEAUVOIR, Simone. The second sex. Translated and edites by H.M.Parshley. New York: Knopf, 1953; reprint ed., 1974.

DUARTE, Lélia Parreira. Ironia e humor na literatura. Belo Horizonte: Ed. PUC Minas; São Paulo: Alameda, 2006.

FAGAN, Cathy E. The price of power in women's literature: edith Wharton and Dorothy Parker. In: BAKERMAN, Jane S. (Ed.). Gender in popular culture: images of men and women in literature, visual media, and material culture. Cleveland, OH: Ridgemont, 1995. p. 227-246.

FORD’S, Corey. The time of laughter. Boston: Little, Brown, 1967.

FREUD, Sigmund. Os chistes e sua relação com o inconsciente. Rio de Janeiro: Imago, 1905. v. 3.

FREWIN, Leslie. The late mrs. Dorothy Parker. New York: Macmillan, 1986.

HARRIMAN, Margaret Chase. The vicious circle. New York: Rinehart \& Company, 1951. HEAD, Dominique. The modernist short story. Cambridge: Cambridge University Press, 1994.

HEMINGWAY, Ernest. In our time. New York: Charles Scribner’s Sons, 1958.

HOBBES, Thomas. Leviatã. Trad. João Paulo Monteiro e Maria Beatriz Nizza da Silva. Lisboa: INCM, 2002.

HUGHES, Langston. The book of negro humor. New York: Dodd, Mead, 1966. 
HUTCHEON, Linda. Teoria e política da ironia. Belo Horizonte: Ed. UFMG, 2000.

JOHNSON, Ken. Dorothy Parker's perpetual motion. In: BROWN, Julie (Ed.). American women short story writers: a collection of critical essays. New York: Garland, 1995.

KANT, Immanuel. Crítica da faculdade do juízo. 2. ed. Rio de Janeiro: Forense Universitária, 2005.

KEATS, John. You might as well live: the life and times of Dorothy Parker. New York: Simon \& Schuster, 1970.

KEHL, Maria Rita. Deslocamentos do feminino. Rio de Janeiro: Imago, 1998.

KERBER, Linda K.; DE HART, Jane Sherron. Women's America: refocusing the past. New York: Oxford University Press, 1982.

KINNEY, Arthur F. Dorothy Parker. Boston: Twayne Publishers, 1978.

Her life: the events leading up to the tragedy. In: Dorothy Parker. Revised. New York: Twayne, 1998.

KLINE, Virginia. Dorothy Parker. In: GALE, Steven H. (Ed.). Encyclopedia of American Humorists. New York: Garland, 1988. p. 344-349.

KNIGHT, Charles. The literature of satire. Cambridge: Cambridge University Press, 2004. LABRIE, Ross. Dorothy Parker revisited. Canadian Review of American Studies, v. 7, p. 48-56, 1976.

LAIN-ENTRALGO, Pedro (Org.). Historia universal de la medicina. Barcelona: Salvat, 1972.

LEITE, Ligia Chiappini Moraes. O foco narrativo. São Paulo: Ática, 1985. (Série Princípios).

MAGALHÃES JÚNIOR, R. A arte do conto: sua história, seus gêneros, sua técnica, seus mestres. Rio de Janeiro: Bloch, 1972.

MAIR, John. New novels. Review of Here Lies. New Statesman and Nation, 1939.

MATTHEWS, Brander. The philosophy of the short story. P. Smith, 1931.

MAY, Charles E. (Ed.) Short story theories. Athens: Ohio University Press, 1976. 
MEADE, Marion. Dorothy Parker: what fresh hell is this? New York: Villard Books, 1988.

MELZER, Sondra. The rhetoric of rage: women in Dorothy Parker. New York: Peter Lang, 1997.

MILLER, Nina. Making love modern: the intimate public worlds of New York's literary women. New York and Oxford: Oxford University Press, 1999.

MINOIS, Georges. História do riso e do escárnio. São Paulo: Ed. UNESP, 2003.

MUERCKE, D.C. Irony. The critical idiom. London: Methuen, 1970.

PEARN, Dominique de Saint. A extravagante Dorothy Parker. Rio de Janeiro: Civilização Brasileira, 1997.

PERELMAN, J. S. The Most of S. J. Perelman, Dorothy Parker. Introduction. New York: Simon and Schuster, 1958.

PETTIT, Rhonda. A gendered collision: sentimentalism and modernism in Dorothy Parker's poetry and fiction. Cranbury, NJ: Fairleigh Dickinson University Press, 2000.

PIGLIA, Ricardo. Formas breves. São Paulo: Companhia das Letras, 2000.

PIRANDELLO, Luigi. O humorismo. São Paulo: Ed. Experimento, 1996.

POLLAK, Ellen. Premium swift: Dorothy Parker's iron mask of femininity. In: MELL, Donald C. (Ed.). Pope, swift, and women writers. Newark: U of Delaware P; Associated UP, 1996. p. 203-212.

PROPP, Vladimir. Comicidade e riso. São Paulo: Ática, 1992.

ROSS, Danforth. O conto norte-americano. São Paulo: Martins Ed., 1964.

ROURKE, Constance. American humor: a study of the nacional character. Garden City, N.Y.: Doubleday Anchor Books, 1953.

SCHAEFFER, Neil. The art of laughter. New York: Columbia University Press, 1981.

SCHOPENHAUER, Artur. The world as will and representation, 1818. Translated by E.F.J. Payne. New York: Harper \& Row, 1968. v. 1. 
TOTH, Emily. Dorothy Parker, Erica Jong, and new feminist humor. Regionalism and the Female Imagination, v. 2, n. 2, p. 70-85, 1977.

TREICHLER, Paula A. Verbal subversions in Dorothy Parker: "trapped like a trap in a trap". Language and Style: an international journal, v. 13, n. 4, p. 46-61, 1980.

VOGUE, July 1944.

VV.AA. The new feminist criticism. New York: Pantheon Books, 1985.

WALKER, Nancy. The remarkably constant reader: Dorothy Parker as book reviewer. Studies in American Humor, New Series, v. 3, n. 4, p. 1-14, 1997.

A very serious thing: women's humor and American culture. Minneapolis: University of Minnesota Press, 1988.

; DRESNER, Zita (Eds.). Redressing the balance: american women's literary humor from colonial times to the 1980s. Jackson and London: University Press of Mississippi, 1988.

WHITE, E. B.; WHITE, Katherine S. (Eds.). A subtreasury of American Humor. New York: Coward-McCann, 1941.

WOOLlCOTT, Alexander. While Rome burns "Our Mrs. Parker". New York: Viking, 1934.

WRITERS at Work: The Paris Review Interviews, p. 69-82.

\section{TESES}

BUYNO, Nancy Isabel Campbell. American humor and Canadian humor: Mark Twain and Stephen Leacock - a paralel study. 1987. Tese (Doutorado em Literatura NorteAmericana) - FFLCH - Faculdade de Filosofia, Letras e Ciências Humanas, São Paulo, 1988.

LIMA, Teresa Marques de Oliveira. A presença do humor nos romances de Eudora Welty. 1997. Tese (Doutorado em Literatura Norte-Americana) - FFLCH - Faculdade de Filosofia, Letras e Ciências Humanas, São Paulo, 1997. 